\title{
Modular Pebble-Bed Reactor Project \\ Laboratory-Directed Research and Development Program FY 2002 Annual Report
}

David A. Petti (editor)

Thomas J. Dolan

Gregory K. Miller

Richard L. Moore

William K. Terry

Abderaffi M. Ougouag

Change $\mathrm{H}$. Oh

Hans D. Gougar

November 2002

Idaho National Engineering and Environmental Laboratory Bechtel BWXT Idaho, LLC 


\title{
MODULAR PEBBLE-BED REACTOR PROJECT
}

\section{LABORATORY-DIRECTED RESEARCH AND DEVELOPMENT PROGRAM \\ FY2002 ANNUAL REPORT}

\section{IDAHO NATIONAL ENGINEERING AND ENVIRONMENTAL LABORATORY}

\author{
David A. Petti, Thomas J. Dolan, Gregory K. Miller Richard L. Moore William \\ K.Terry, Abderrafi M. Ougouag, Chang H. Oh, Hans D. Gougar
}

November 2002

Idaho National Engineering and Environmental Laboratory

Idaho Falls, Idaho 83415

Prepared for the

U.S. Department of Energy

Assistant Secretary for Environmental Management

Under DOE Idaho Operations Office

Contract DE-AC07-99ID13727 


\section{EXECUTIVE SUMMARY}

This report documents the results of our research in FY-02 on pebble-bed reactor technology under our Laboratory Directed Research and Development (LDRD) project entitled the Modular Pebble-Bed

Reactor. The MPBR is an advanced reactor concept that can meet the energy and environmental needs of future generations under DOE's Generation IV initiative. Our work is focused in three areas: neutronics, core design and fuel cycle; reactor safety and thermal hydraulics; and fuel performance.

\section{Fuel Performance}

In the area of fuel performance, our work focused on the development of a chemistry module for the PARticle FUel ModEl (PARFUME) computer code. The purpose of the module was to estimate the chemical forms of fission products formed by fission of U-235 in a fuel kernel containing a mixture of $\mathrm{UO}_{2}$ and $\mathrm{UC}_{2}$ at various $\mathrm{UC}_{2}$ fractions, enrichments, burnup values, and temperatures, and to estimate the partial pressures of $\mathrm{CO}, \mathrm{CO}_{2}$, and noble gases in the kernel-buffer zone of the fuel particles. These results are needed to calculate stresses and fission product transport in the TRISO-coated particle fuel.

Two chemical equilibrium codes, HSC and FACTSAGE, were compared. For a test case the concentrations of substances predicted by the two codes agree in general, but HSC shows a spread of valence distributions while FACTSAGE does not. HSC was chosen for subsequent computations. The 30 dominant fission products were combined into 12 families to facilitate computations.

Equilibria have been calculated for a system with $\mathrm{UO}_{2}, \mathrm{UC}_{2}, \mathrm{Pu}, \mathrm{C}, \mathrm{O}_{2}$, and 12 fission product groups, for which 241 output substances are possible. The equilibria have been computed at 5 values of fuel enrichment, $8 \mathrm{UC}_{2}$ fractions, 7 values of fuel burnup, and 18 temperatures, yielding a database of about 4600 equilibria. The CO concentration predicted by HSC varies slowly with burnup and fuel enrichment, but strongly with temperature. The $\mathrm{CO}$ yield is high with no $\mathrm{UC}_{2}$ present, but drops rapidly to a plateau at $\mathrm{UC}_{2}$ fractions above $10 \%$, then drops to zero as the $\mathrm{UC}_{2}$ fraction approaches $100 \%$. There is also a substantial yield of $\mathrm{CO}_{2}$ in pure $\mathrm{UO}_{2}$ fuel, but not in $\mathrm{UCO}$ fuel. At $\mathrm{T}>1500 \mathrm{~K}$ the ability of lanthanides 
to bind oxygen decreases, so the yield of $\mathrm{CO}$ could exceed simplified estimates that assume firm binding by lanthanides at all temperatures.

The results were then fitted to polynomials so that fast calculations can be performed inside PARFUME. The results from the model were compared against previous thermodynamic estimates and empirical data on the release of $\mathrm{CO}$ from $\mathrm{UO}_{2}$ coated particle fuel. Pressures of $\mathrm{CO}, \mathrm{CO}_{2}$, and noble gases were calculated for a specific fuel design. The $\mathrm{CO}$ and $\mathrm{CO}_{2}$ pressure in $\mathrm{UCO}$ fuel is negligible as expected. However for pure $\mathrm{UO}_{2}$ fuel significant $\mathrm{CO}$ pressures are predicted. The thermodynamic estimates of $\mathrm{CO}$ yield exceed the predictions of CO release from crushed fuel particles; the difference may be due to incomplete conversion of the excess oxygen to $\mathrm{CO}$ in the particle. However, the thermodynamic model agrees with a thermodynamic estimate of yield assuming the lanthanide fission products form trivalent oxides.

\section{Reactor Safety and Thermal Hydraulics}

Work continued from the previous year in the area of air ingress into pebble-bed reactors. A loss-ofcoolant accident (LOCA) has traditionally been considered a design-basis accident for helium-cooled pebble-bed reactors. Following helium depressurization, it is anticipated that unless countermeasures are taken air will enter the core through the break and then by molecular diffusion and ultimately by natural convection cause oxidation of the in-core graphite structure and graphite pebbles to occur. Thus, without any mitigating features a LOCA will lead to an air ingress event. We have studied such an event with two well-respected light water reactor transient response codes: RELAP5/ATHENA and MELCOR.

To study the degree of core oxidation occurring in a beyond-design-basis air ingress accident, a complete system model using the MELCOR code was developed to describe the behavior of the reactor and surrounding systems. (A modified version of MELCOR developed at INEEL, which includes graphite oxidation capabilities and molecular diffusion of air into helium, was used for these calculations.) Sensitivity studies were performed to determine the response of the system to changes in the air oxidation rate of the pebbles, the functioning of the reactor cavity cooling system (convection vs. natural convection), the availability of air in the surrounding vault, and the location of the break in the cooling system (hot leg vs. cold leg). The accident progression is similar in all cases: following depressurization of the helium, there is a period of stagnation in the reactor during which the air must diffuse into the helium before there is enough driving force in the reactor to begin natural circulation. Once natural circulation begins, a small amount of air enters the reactor and causes oxidation. Changes in the air oxidation rate and the mode of cooling on the outside of the vessel affect the time at which the natural 
circulation begins and the location of the oxidation in the lower reflector region. However, in all cases examined thus far the oxidation is limited to that in the lower reflector region and fuel is not threatened; fuel temperatures are similar to those expected during a traditional conduction cooldown. Future work is directed at using the oxidation rates of the actual graphite pebbles used in the AVR in Germany; these rates are lower than that used by us previously and thus may shift the oxidation front into the core region, which may be undesirable from a safety standpoint.

\section{Neutronics, core design and fuel cycle}

In the area of neutronics, core design and fuel cycle, advancements were made in the PEBBED code and PEBBED was applied to address problems of practical interest in pebble-bed reactor technology. The advancements in PEBBED include development of a three-dimensional version, improvements in the matrix formulation of pebble recirculation, enhancements of the depletion solver, and development of heat-transfer models.

The three-dimensional version of PEBBED, PEBBED3, was initiated. In PEBBED3, there are two options for the solution of the neutron diffusion equation in general three-dimensional cylindrical geometry. The first option is a standard finite-difference solution; this option is now fully operational. The second option is a nodal solution; this option is still being implemented.

Many pebble-bed core designs feature a two-zone core that may yield improved fuel economy and heat transfer over randomly loaded single-zone cores like the HTR Modul. For example, the South African PBMR consists of a graphite central zone and a fueled outer zone. The relative sizes of the zones are determined by the relative flow rates of pebbles through the inner and outer loading tubes; there is no physical barrier between the zones. In burnup-dependent two-zone cores, pebbles are loaded fresh into one zone and, at some point in their burnup history, transferred to the other zone. Previously, such cores were modeled in PEBBED by manually generating the recirculation matrix "off-line" and reading it into the code. The matrix algorithm was upgraded in PEBBED3 to generate the recirculation matrices internally and automatically for multiple pebble types tracing independent paths through two-zone cores. Complex cores of this type can be modeled and optimized through the manipulation of a few key parameters in the input deck.

In PEBBED2, only one fissile nuclide could be specified in the fuel. The accuracy obtainable in modeling pebble-bed cores with high burnup or multiple fuel types was improved by enabling the code to compute fission yields for up to three fissile isotopes. Most core designs contain uranium-235 as the 
dominant fuel type, but in high-burnup cores a significant buildup of Pu-239 can occur. Cores containing fertile thorium will build in a large amount of fissile U-233. The fission-product yields of these fuel isotopes differ; thus, different fuel mixes will produce different nuclide distributions and discharge isotopics. PEBBED3 is able to compute and track depletion and buildup in multi-fuel cores.

A one-dimensional heat transfer model implemented in PEBBED2 has been improved for PEBBED3. The fuel temperature module was improved by adding a graphite thermal conductivity correlation dependent on temperature and neutron fluence. The correlation developed at Oak Ridge National Laboratory, accurately accounts for the thermal conductivity in a pebble given its irradiation history. Coupled with the zone-dependent axial coolant temperature calculation, the correlation gives good approximations of pebble fuel temperature throughout the core and over the history of a given pebble type.

In addition, post-accident fuel temperatures following a result of a loss of coolant flow were estimated using a one-dimensional (radial) transient heat conduction/radiation module implemented in PEBBED3. The temperatures were shown to depend strongly on the steady-state core power density. This feature allows a core optimization study to include the post-accident peak temperature as one of the parameters in an overall objective function.

The subcontract work with the Georgia Institute of Technology continued. The codes originally planned for use in cross-section processing, COMBINE and TORT, had been shown in FY-01 to be unsuitable; in FY-02 the codes WIMS and EVENT were selected, tested, and shown to be appropriate.

Since PEBBED is being developed as a practical tool with which to answer questions about the performance of real PBRs, it is appropriate to test its capabilities at each stage in its development by applying it to address practical issues. During FY-02, PEBBED was used to investigate questions on the deployment of PBRs in remote locations and on the susceptibility of PBRs to be used for nuclear weapons proliferation. Our work on nonproliferation of nuclear weapons has shown that the PBR is a poor choice for overt or covert production of nuclear weapons material. 


\section{ACKNOWLEDGMENTS}

The authors are grateful to Alan Herbst and Rob Bratton for provision of the HSC and FACTSAGE codes, and to Jerry Christian, Dick Hobbins, and David Martin for helpful discussions. 


\section{CONTENTS}

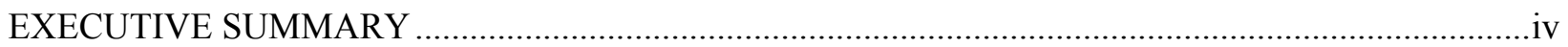

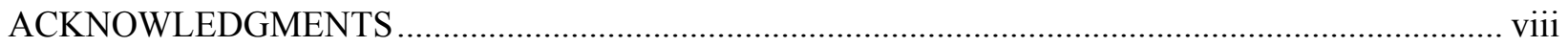

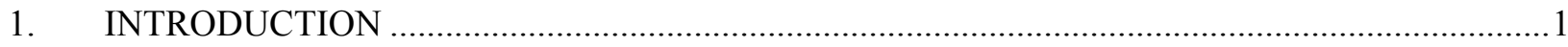

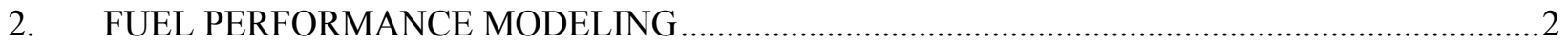

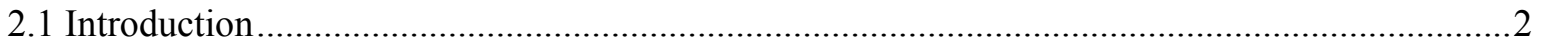

2.2 Chemical Behaviors of Fuels and Fission Products ...............................................................

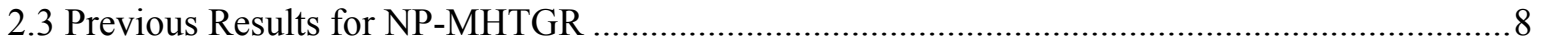

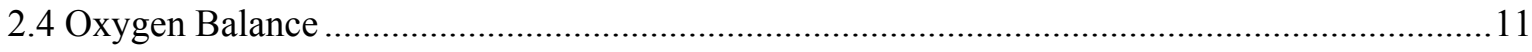

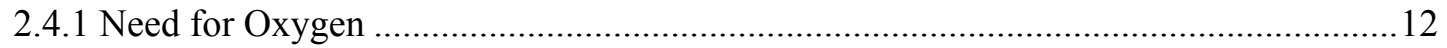

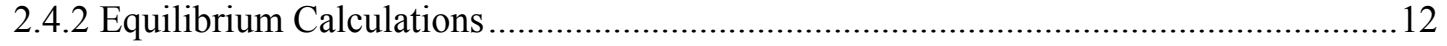

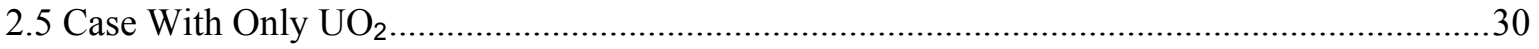

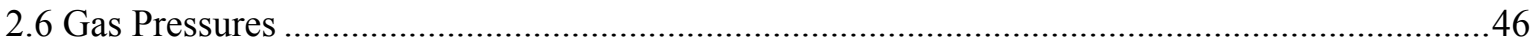

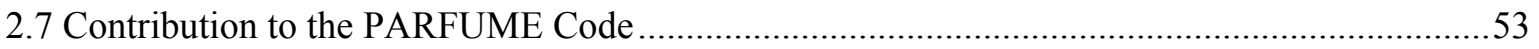

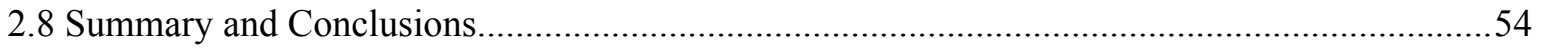

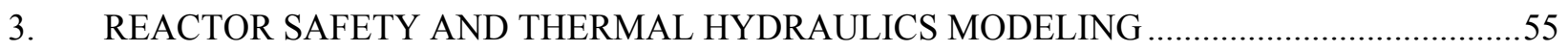

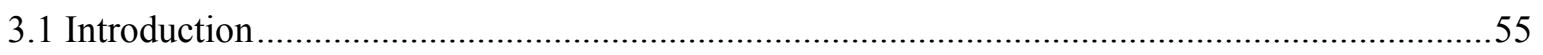

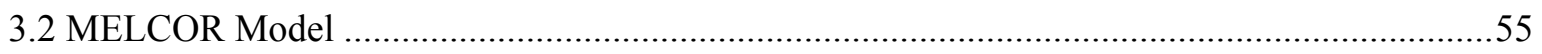

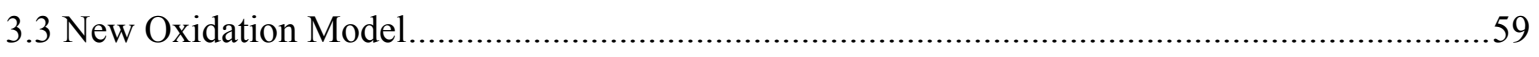

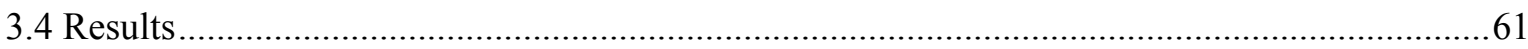

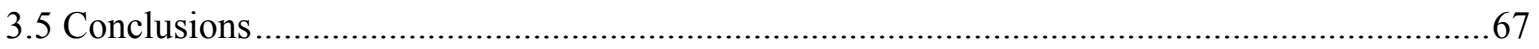

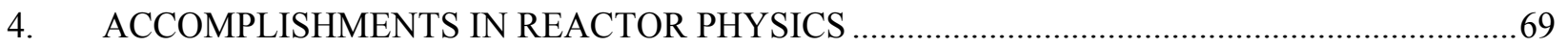

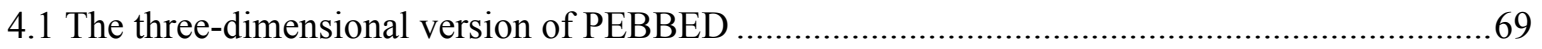

4.2 Improvements in the matrix formulation of pebble recirculation ........................................... 70

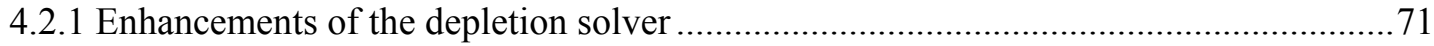

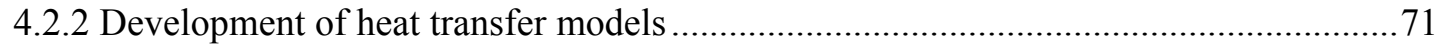

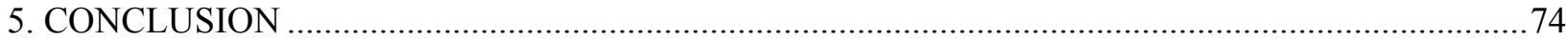




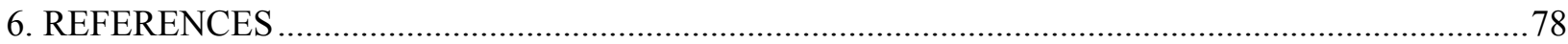

APPENDIX A. ANTICIPATED BEHAVIORS OF VARIOUS FUELS AND FISSION

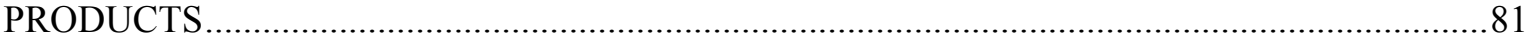

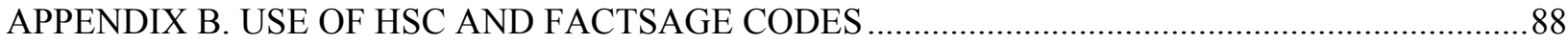

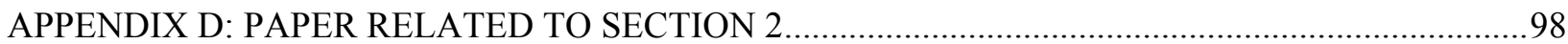

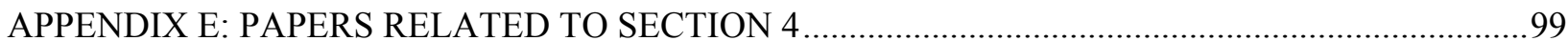




\section{FIGURES}

Figure 2-1. Species present in fuel particle. Neutron capture in $\mathrm{UO}_{2}$ and $\mathrm{UC}_{2}$ breeds $\mathrm{Pu}$, generates fission products (FP), and liberates $\mathrm{O}$ and $\mathrm{C}$.

Figure 2-2. Gibbs energies of oxide formation (per g-atom of oxygen) of $\mathrm{U}, \mathrm{Pu}, \mathrm{Si}$, carbon, and 24 fission products computed with the HSC code.

Figure 2-3. Oxygen potential of various elements vs. temperature ( McCardell 1992). Elements with large negative oxygen potentials form the most stable oxides.

Figure 2-4. CO yield per gram(U) vs. temperature at various burnup values for a case with $\mathrm{e}=$ $20 \%, \mathrm{c}=30 \%$. The $\mathrm{CO}$ yield per pebble is nine times larger. A burnup of $191 \mathrm{MWd} / \mathrm{kg}$ is equivalent to an atomic burnup of $20 \%$ (Table 2-4).

Figure 2-5. CO yield per fission vs. temperature at various values of burnup for a case with $\mathrm{e}=$ $20 \%, \mathrm{c}=30 \%$.

Figure 2-6. CO yield per gram(U) vs. burnup at various temperatures for a case with $\mathrm{e}=20 \%$, c $=30 \%$. The CO yield per pebble is nine times larger. A burnup of $191 \mathrm{MWd} / \mathrm{kg}$ is equivalent to an atomic burnup of $20 \%$ (Table $2-4$ ).

Figure 2-7. CO yield per fission vs. burnup at various temperatures, for a case with $\mathrm{e}=10 \%, \mathrm{c}$ $=30 \%$.

Figure 2-8 Variation of $\mathrm{CO}$ yield per gram $(\mathrm{U})$ with burnup at $\mathrm{T}=1700 \mathrm{~K}, \mathrm{e}=20 \%, \mathrm{c}=30 \%$.

Figure 2-9. CO yield per fission vs. burnup at $\mathrm{T}=1700 \mathrm{~K}, \mathrm{e}=20 \%, \mathrm{c}=30 \%$

Figure 2-10. $\mathrm{CO}$ yield per fission vs. temperature at various $\mathrm{UC}_{2}$ fractions for a case with $\mathrm{e}=$ $10 \%, \mathrm{~b}=81 \mathrm{MWd} / \mathrm{kg}$.

Figure 2-11. $\mathrm{CO}$ yield per fission vs. $\mathrm{UC}_{2}$ fraction at various temperatures for a case with $\mathrm{e}=$ $10 \%, \mathrm{~b}=81 \mathrm{MWd} / \mathrm{kg}$.

Figure 2-12. Details of the $\mathrm{c}=0-10 \%$ region, $\mathrm{CO}$ yield per fission vs. $\mathrm{UC}_{2}$ fraction at various temperatures for a case with $\mathrm{e}=10 \%, \mathrm{~b}=81 \mathrm{MWd} / \mathrm{kg}$.

Figure 2-13. Ratio $\mathrm{CO}$ yield per fission at various enrichments to the yield at $\mathrm{e}=10 \% \mathrm{vs}$ enrichment, for a wide variety of other parameters. Legend notation: "19,10,1000" means $\mathrm{b}=19 \mathrm{MWd} / \mathrm{kg}, \mathrm{c}=10 \%, \mathrm{~T}=1000 \mathrm{~K}$.

Figure 2-14. $\mathrm{CO}$ yield per gram $(\mathrm{U})$ vs. temperature for case with pure $\mathrm{UO}_{2}$ fuel $(\mathrm{c}=0)$, e $=$ $10 \%$ at various values of burnup. The yield per fuel pebble is nine times as large. 
Figure 2-15. $\mathrm{CO}_{2}$ yield per fission vs. temperature for pure $\mathrm{UO}_{2}$ fuel, e $=10 \%$, at various values of burnup.

Figure 2-16. $\mathrm{CO}$ yield per gram(U) vs. burnup, for case with pure $\mathrm{UO}_{2}$ fuel $(\mathrm{c}=0 \%), \mathrm{e}=10 \%$ at various temperatures. The yield per fuel pebble is nine times larger.

Figure 2-17. $\mathrm{CO}$ yield per fission vs. burnup in pure $\mathrm{UO}_{2}$ fuel with $\mathrm{e}=10 \%$, at various temperatures

Figure 2-18. $\mathrm{CO}_{2}$ yield vs. Temperature for pure $\mathrm{UO}_{2}$ fuel with $\mathrm{e}=10 \%$, at various values of burnup.

Figure 2-19. Concentration ratio of $\mathrm{CO}_{2} / \mathrm{CO}$ vs. temperature, for a case with $\mathrm{e}=10 \%, \mathrm{c}=30 \%$, $\mathrm{b}=113 \mathrm{MWd} / \mathrm{kg}$.

Figure 2-20. $\mathrm{HSC}$ predictions of $\mathrm{CO}$ yield per fission vs. temperature for a case with pure $\mathrm{UO}_{2}$ fuel $(\mathrm{c}=0)$ ), compared with empirical formulas (Proksch 1982 and Kovacs 1985) at $\mathrm{t}=$ 213 days (roughly $19 \mathrm{MWd} / \mathrm{kg}$ ).

Figure 2-21. HSC predictions of $\mathrm{CO}$ yield per fission vs. temperature for a case with pure $\mathrm{UO}_{2}$ fuel $(\mathrm{c}=0)$ ), compared with empirical formulas (Proksch 1982 and Kovacs 1985) at $\mathrm{t}=$ 573 days (approximately $50 \mathrm{MWd} / \mathrm{kg}$ ).

Figure 2-22. Fraction of fissions occurring in plutonium vs. burnup, for various enrichments. .42

Figure 2-23. CO yield per fission vs. time at $1200 \mathrm{~K}$, HSC predictions compared with the Proksch correlation.

Figure 2-24. Comparison of HSC estimate of $\mathrm{CO}$ yield per fission at $1500 \mathrm{~K}$ with the Proksch (1982) correlation, with the Proksch (1982) theoretical estimates (dependent on valence of lanthanides), and with the empirical algorithm of Horsley (1976).

Figure 2-25. CO yield per fission vs. time at $1800 \mathrm{~K}$, HSC predications compared with Proktsch algorithms.

Figure 2-26. Pressures of $\mathrm{CO}$ and $\mathrm{CO}_{2}$ in pure $\mathrm{UO}_{2}$ fuel vs. temperature, at various enrichments and burnups

Figure 2-27. Total pressure of $\mathrm{CO}+\mathrm{CO}_{2}$ in pure $\mathrm{UO}_{2}$ fuel vs. temperature, for various enrichments and burnups. The bottom curve shows the peak $\mathrm{CO}_{2}$ pressure.

Figure 2-28. CO pressure vs. temperature in UCO fuel with $\mathrm{c}=30 \% \mathrm{vs}$. temperature, at various enrichments and burnup values.

Figure 2-29. CO pressure vs. burnup in UCO fuel with e $=20 \%, \mathrm{c}=30 \%$, at various temperatures

Figure 2-30. Pressure of $(\mathrm{Xe}+\mathrm{Kr})$ vs. burnup at $\mathrm{c}=30 \%, \mathrm{~T}=2000 \mathrm{~K}$, various enrichments. .53

Figure 3.1 Pebble-Bed Control Volume diagram. .57

Figure 3.2 Pebble-Bed Heat Structure Diagram. .58 
Figure 3.3 Comparison of INEL-1988 and INEEL-2002 carbon-air reaction rates.

Figure 4.4 Core and lower reflector temperatures using INEEL-1988 correlation...... 62

Figure 3.5 Core and lower reflector temperatures using INEEL-2002 correlation....... 62

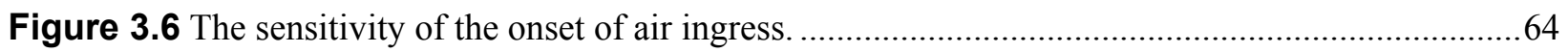

Figure 3.7 Core and lower reflector temperatures corresponding to natural convection in reactor cavity

Figure 3.8 Core and lower reflector temperatures corresponding to a cold leg break. 66

Figure 3.9 Influence of vault volume on lower reflector temperature and onset of natural convection using INEEL 1988 reaction rate correlation ...............................................................68 


\section{TABLES}

Table 2-1. Yields of fission products in fuel pebbles at $\mathrm{b}=66 \mathrm{MW}-\mathrm{d} / \mathrm{kg}, \mathrm{e}=10 \%($ Weaver 2001)....... 5

Table 2-2. Summary of anticipated oxide formation. Yields shown are for a case with $b=66 \mathrm{MWd} / \mathrm{kg}$, $\mathrm{e}=10 \% . \Delta \mathrm{G}_{\mathrm{f}}^{\mathrm{o}}$ values are computed by HSC.

Table 2-3. Total plutonium content in fuel (mol Pu/fuel pebble) vs. burnup. (Based on results of Weaver 2001). To get $\mathrm{mol}(\mathrm{Pu}) / \mathrm{gram}(\mathrm{U})$, divide by 9 .

Table 2-4. Relation between burnup and time.

Table 2-5. Input data for a case with $\mathrm{e}=10 \%, \mathrm{c}=30 \%$. Quantities are mol per fuel pebble. (To get $\mathrm{mol} / \mathrm{gram}(\mathrm{U})$, divide by 9.$)$.

Table 2-6. Parameter values used in HSC calculations. No computations were done for $\mathrm{b}>81 \mathrm{MWd} / \mathrm{kg}$ at $\mathrm{e}=7$ or $8 \%$, because $\mathrm{k}_{\text {eff }}<1$ for those cases.

Table 2-7. Concentrations (mol/pebble), $\mathrm{e}=10 \%, \mathrm{c}=30 \%, \mathrm{~b}=113 \mathrm{MWd} / \mathrm{kg}$ (To get $\mathrm{mol} / \mathrm{gram}(\mathrm{U})$, divide by 9.).....

Table 2-8. Concentrations (mol/pebble) in pure $\mathrm{UO}_{2}$ fuel with $=10 \%, \mathrm{~b}=113 \mathrm{MWd} / \mathrm{kg}$.......... 32

Table 2-9. Yield (mol/pebble) of $\mathrm{CO}$ and $\mathrm{CO}_{2}$ vs. temperature, comparing two values of buffer density, $\rho$ $=085$ and $1.1 \mathrm{~g} / \mathrm{cm}^{3}$. Here "e20c00b191" means e $=20 \%, \mathrm{c}=0, \mathrm{~b}=191 \mathrm{MWd} / \mathrm{kg}$.

Table A-1. Gibbs Energies of formation of various oxides (kJ per g-atom of oxygen) vs. temperature (K), computed with HSC.

Table B-1. Fission product groups used for code comparisons and fractional yields for case with $b=66$ $\mathrm{MWd} / \mathrm{kg}, \mathrm{e}=10 \%$.

Table B-2. Input data for equilibrium codes. Quantities (mol/fuel pebble) of fission products generated, fuels remaining, and $\mathrm{O}_{2}$ and $\mathrm{C}$ released vs. burnup for a case with $\mathrm{c}=30 \%$ and $\mathrm{e}=10 \%$.

Table B3. Possible substances resulting from 11 input materials $\left(\mathrm{UO}_{2}, \mathrm{UC}_{2}, \mathrm{Pu}, \mathrm{O}_{2}, \mathrm{C}, \mathrm{Zr}, \mathrm{Xe}, \mathrm{Mo}, \mathrm{La}\right.$, $\mathrm{Cs}, \mathrm{Sr}$ ). (Shaded boxes were not used in computations.).

Table B4. Some inconsistencies between internal databases of HSC and FACTSAGE. Gibbs energies of compounds $\mathrm{G}(\mathrm{kJ} / \mathrm{mol})$ (not $\Delta \mathrm{G}_{\mathrm{f}}{ }^{\text {ofor }}$ formation of the compounds) at $1300 \mathrm{~K}$.

Table B5. FACTSAGE and HSC comparison at $\mathrm{b}=113 \mathrm{MWd} / \mathrm{kg}, \mathrm{c}=30 \%, \mathrm{e}=10 \%, \mathrm{~T}=1300 \mathrm{~K}$. 


\section{INTRODUCTION}

The Modular Pebble-Bed Reactor (MPBR) is an advanced reactor concept that can meet the energy and environmental needs of future generations as defined under DOE's Generation IV initiative. Preliminary research has concluded that this technology has an excellent opportunity to satisfy the safety, economic, proliferation, and waste disposal concerns that face all nuclear electric generating technologies. During Fiscal Year 2002, in collaboration with the Massachusetts Institute of Technology (MIT), we have pursued a greater understanding of the potential for the MPBR program to address these concerns. Our work in collaboration with MIT is focused on developing, benchmarking, and applying core design tools in the areas of neutronics, thermal hydraulics, fuel performance, and safety analysis. This strategy will allow INEEL to address the important issues that face the MPBR and to have a complete integrated reactor core design capability for the MPBR. In this report, we provide a description of progress made in the past year. MIT's work is documented in a separate report. 


\section{FUEL PERFORMANCE MODELING}

The work in FY-02 focused around the development of a chemistry module for the PARFUME code. This module will estimate the chemical forms of fission products formed by fission of U-235 in a fuel kernel containing a mixture of $\mathrm{UO}_{2}$ and $\mathrm{UC}_{2}$ at various $\mathrm{UC}_{2}$ fractions, enrichments, burnup values, and temperatures, and to estimate the partial pressures of $\mathrm{CO}, \mathrm{CO} 2$, and noble gases in the kernel buffer zone of the fuel particles. These results are needed to calculate stresses and fission product transport in the TRISO-coated particle fuel.

\subsection{Introduction}

The purpose of this study is to estimate the chemical forms of fission products (FP) formed by fission of $\mathrm{U}-235$ in a fuel kernel containing a mixture of $\mathrm{UO}_{2}$ and $\mathrm{UC}_{2}$, for various temperatures and burnups, and to estimate the partial pressures of $\mathrm{CO}$ and noble gases in the kernel-buffer zone. These pressures are needed to calculate the stresses on the inner pyrolytic carbon (IPyC), SiC, and outer pyrolytic (OPyC) layers and the chemical forms are used to calculate fission product transport through those layers in TRISO-coated particle fuel.

The model fuel pebbles (based on a German design) have an inner region containing a mixture of graphite and 15,000 tiny fuel particles, and an outer region of pure graphite (diameter $6 \mathrm{~cm}$ ). It is assumed that there are 9 gram $(\mathrm{U})$ per pebble. The TRISO-coated fuel particles have the following nominal dimensions:

$\begin{array}{ll}\text { Inner fuel kernel diameter } & =500 \mu \mathrm{m} \\ \text { Graphite buffer layer thickness } & =95 \mu \mathrm{m} \\ \text { Inner pyrolytic carbon layer thickness } & =40 \mu \mathrm{m} \\ \text { Silicon carbide layer thickness } & =35 \mu \mathrm{m} \\ \text { Outer pyrolytic carbon layer thickness } & =40 \mu \mathrm{m} \\ \text { Outer diameter of particle } & =920 \mu \mathrm{m} .\end{array}$


The buffer region separates the fuel kernel from the IPyC shell, absorbs fission fragment energy, and provides a void volume to collect fission gases, so it needs to have a high porosity. The buffer density is assumed to be $0.85 \mathrm{~g} / \mathrm{cm}^{3}$, which corresponds to a porosity of $61 \%$. There are $7.55 \times 10^{-6} \mathrm{~mol}(\mathrm{C})$ per particle (or $0.113 \mathrm{~mol}(\mathrm{C}) /$ pebble) in the buffer regions. (Some cases with buffer density $=1.1 \mathrm{~g} / \mathrm{cm}^{3}$ (porosity 50\%) were also studied for comparison.).

Each fission in $\mathrm{UO}_{2}$ releases 2 fission products plus 2 oxygen atoms, and each fission in $\mathrm{UC}_{2}$ releases 2 fission products plus 2 carbon atoms. Plutonium is bred in the ${ }^{238} \mathrm{U}$. Thus, there will be $\mathrm{UO}_{2}, \mathrm{UC}_{2}, \mathrm{Pu}$ (possibly forming oxides and carbides), carbon atoms, oxygen atoms, and fission products present, as illustrated in Figure 2-1.

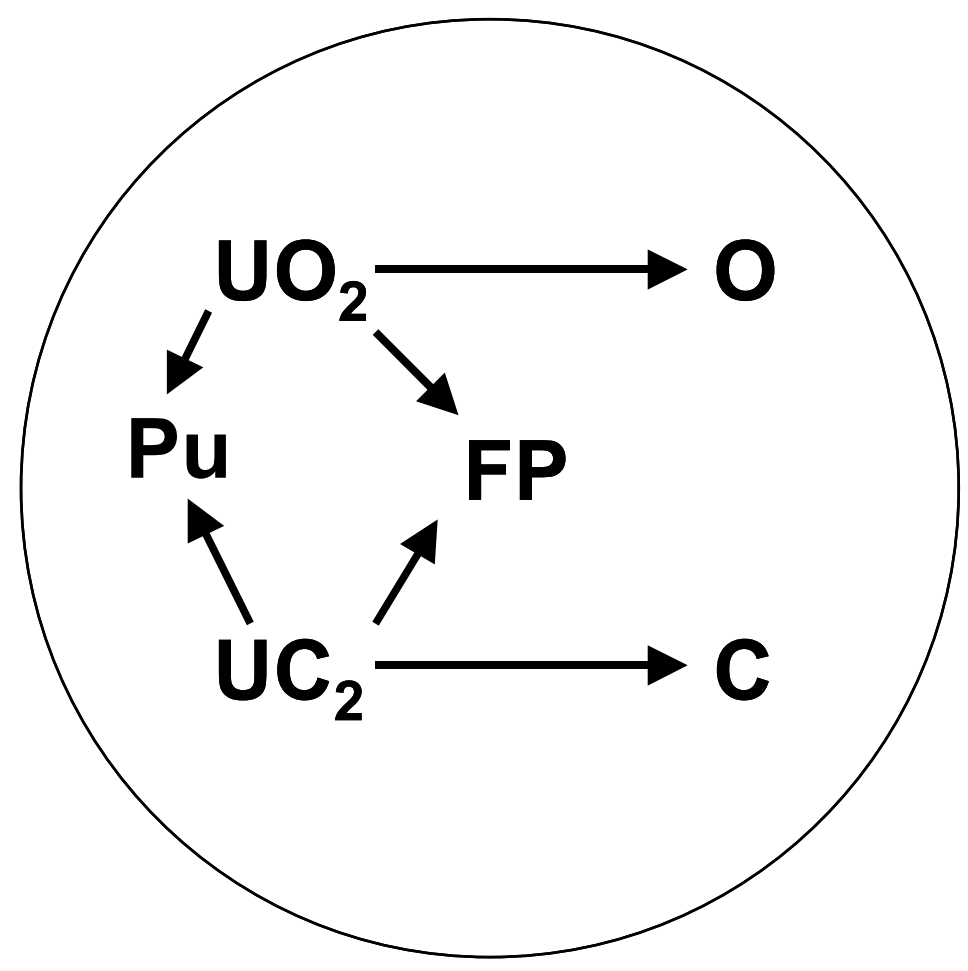

Figure 2-1. Species present in fuel particle. Neutron capture in $\mathrm{UO}_{2}$ and $\mathrm{UC}_{2}$ breeds $\mathrm{Pu}$, generates fission products (FP), and liberates $\mathrm{O}$ and $\mathrm{C}$. 
The input to the present calculations is tables of fission product yield vs. fuel enrichment and burnup. It is desired to understand the chemical form (carbide, oxide, or other) of each fission product and to estimate the quantities of $\mathrm{CO}$ and other gases produced. It is assumed that:

(1) The fission product mobility within the kernel-buffer region is high enough for the atoms to interact chemically with any species that are present

(2) The fission products reach chemical equilibrium faster than they are lost by diffusion through the shells.

The variables used in this analysis are:

$$
\begin{aligned}
& \mathrm{b}=\text { fuel burnup, } \mathrm{MWd} / \mathrm{kg} \\
& \mathrm{c}=\mathrm{UC}_{2} \text { fraction in fuel, } \% \\
& \mathrm{e}=\text { fuel enrichment, } \% \\
& \mathrm{~T}=\text { fuel temperature, } \mathrm{K} \\
& \mathrm{Y}=\text { yield of carbon monoxide in fuel, molecules }(\mathrm{CO}) \text { per fission. } \\
& \mathrm{p}(\mathrm{CO})=\text { pressure of } \mathrm{CO} \text { in fuel-buffer region, MPa. } \\
& \mathrm{p}(\mathrm{Xe}+\mathrm{Kr})=\text { pressure of (xenon+krypton) in fuel-buffer region, } \mathrm{MPa}
\end{aligned}
$$

\subsection{Chemical Behaviors of Fuels and Fission Products}

The fission yields of 48 fission products were calculated vs. burnup at various enrichments using MOCUP, (Weaver 2001), taking into account plutonium breeding and fission. Using MATLAB software J. Buongiorno derived algorithms to fit these data. (Terry 2001)

For an example case we consider fuel with $10 \%$ enrichment after $66 \mathrm{MWd} / \mathrm{kg}$ burnup. The yields of the 48 fission products are listed in Table 2-1 in order of increasing atomic weight. These elements vary widely in their mobilities and affinities for oxygen. The sum of the fractional yields for Xe and $\mathrm{Kr}$ is 0.15 of the fission products, or 0.30 per fission. This is close to the value of 0.32 given by Lindemer (1977). 
Table 2-1. Yields of fission products in fuel pebbles at $\mathrm{b}=66 \mathrm{MW}-\mathrm{d} / \mathrm{kg}, \mathrm{e}=10 \%$ (Weaver 2001).

\begin{tabular}{|c|c|c|}
\hline Element & (g-atoms / fuel pebble) & Fraction of total FP yield \\
\hline $\mathrm{H}$ & $3.15 \mathrm{E}-07$ & $6.05 \mathrm{E}-05$ \\
\hline $\mathrm{Li}$ & $1.06 \mathrm{E}-09$ & $2.04 \mathrm{E}-07$ \\
\hline $\mathrm{Be}$ & $2.73 \mathrm{E}-10$ & $5.24 \mathrm{E}-08$ \\
\hline $\mathrm{C}$ & $3.38 \mathrm{E}-11$ & $6.48 \mathrm{E}-09$ \\
\hline $\mathrm{Co}$ & $7.13 \mathrm{E}-20$ & $1.37 \mathrm{E}-17$ \\
\hline $\mathrm{Ni}$ & $5.05 \mathrm{E}-17$ & $9.70 \mathrm{E}-15$ \\
\hline $\mathrm{Cu}$ & $6.70 \mathrm{E}-16$ & $1.29 \mathrm{E}-13$ \\
\hline $\mathrm{Zn}$ & $5.91 \mathrm{E}-10$ & $1.13 \mathrm{E}-07$ \\
\hline $\mathrm{Ga}$ & $6.63 \mathrm{E}-12$ & $1.27 \mathrm{E}-09$ \\
\hline $\mathrm{Ge}$ & $1.36 \mathrm{E}-07$ & $2.60 \mathrm{E}-05$ \\
\hline As & $4.00 \mathrm{E}-08$ & $7.68 \mathrm{E}-06$ \\
\hline $\mathrm{Se}$ & $1.29 \mathrm{E}-05$ & $2.47 \mathrm{E}-03$ \\
\hline $\mathrm{Br}$ & $5.07 \mathrm{E}-06$ & $9.73 \mathrm{E}-04$ \\
\hline $\mathrm{Kr}$ & $8.42 \mathrm{E}-05$ & $1.62 \mathrm{E}-02$ \\
\hline $\mathrm{Rb}$ & 7.77E-05 & $1.49 \mathrm{E}-02$ \\
\hline $\mathrm{Sr}$ & $2.06 \mathrm{E}-04$ & $3.96 \mathrm{E}-02$ \\
\hline $\mathrm{Y}$ & $1.06 \mathrm{E}-04$ & $2.04 \mathrm{E}-02$ \\
\hline $\mathrm{Zr}$ & $7.22 \mathrm{E}-04$ & $1.39 \mathrm{E}-01$ \\
\hline $\mathrm{Nb}$ & $9.87 \mathrm{E}-06$ & $1.89 \mathrm{E}-03$ \\
\hline Mo & $5.98 \mathrm{E}-04$ & $1.15 \mathrm{E}-01$ \\
\hline Tc & $1.52 \mathrm{E}-04$ & $2.91 \mathrm{E}-02$ \\
\hline $\mathrm{Ru}$ & $3.84 \mathrm{E}-04$ & $7.37 \mathrm{E}-02$ \\
\hline $\mathrm{Rh}$ & $8.02 \mathrm{E}-05$ & $1.54 \mathrm{E}-02$ \\
\hline $\mathrm{Pd}$ & $1.47 \mathrm{E}-04$ & $2.82 \mathrm{E}-02$ \\
\hline $\mathrm{Ag}$ & $1.05 \mathrm{E}-05$ & $2.01 \mathrm{E}-03$ \\
\hline $\mathrm{Cd}$ & $8.49 \mathrm{E}-06$ & $1.63 \mathrm{E}-03$ \\
\hline In & $3.89 \mathrm{E}-07$ & $7.46 \mathrm{E}-05$ \\
\hline $\mathrm{Sn}$ & $7.29 \mathrm{E}-06$ & $1.40 \mathrm{E}-03$ \\
\hline $\mathrm{Sb}$ & $2.78 \mathrm{E}-06$ & $5.34 \mathrm{E}-04$ \\
\hline $\mathrm{Te}$ & $6.05 \mathrm{E}-05$ & $1.16 \mathrm{E}-02$ \\
\hline $\mathrm{I}$ & $3.08 \mathrm{E}-05$ & $5.91 \mathrm{E}-03$ \\
\hline $\mathrm{Xe}$ & $6.96 \mathrm{E}-04$ & $1.34 \mathrm{E}-01$ \\
\hline Cs & $3.84 \mathrm{E}-04$ & $7.36 \mathrm{E}-02$ \\
\hline $\mathrm{Ba}$ & $1.81 \mathrm{E}-04$ & $3.48 \mathrm{E}-02$ \\
\hline $\mathrm{La}$ & $1.62 \mathrm{E}-04$ & $3.10 \mathrm{E}-02$ \\
\hline $\mathrm{Ce}$ & $3.67 \mathrm{E}-04$ & $7.05 \mathrm{E}-02$ \\
\hline $\operatorname{Pr}$ & $1.42 \mathrm{E}-04$ & $2.73 \mathrm{E}-02$ \\
\hline $\mathrm{Nd}$ & $4.48 \mathrm{E}-04$ & $8.61 \mathrm{E}-02$ \\
\hline $\mathrm{Pm}$ & $3.21 \mathrm{E}-05$ & $6.16 \mathrm{E}-03$ \\
\hline $\mathrm{Sm}$ & 7.34E-05 & $1.41 \mathrm{E}-02$ \\
\hline $\mathrm{Eu}$ & 1.39E-05 & $2.67 \mathrm{E}-03$ \\
\hline $\mathrm{Gd}$ & $4.70 \mathrm{E}-06$ & $9.02 \mathrm{E}-04$ \\
\hline $\mathrm{Tb}$ & $2.17 \mathrm{E}-07$ & $4.16 \mathrm{E}-05$ \\
\hline Dy & $8.60 \mathrm{E}-08$ & $1.65 \mathrm{E}-05$ \\
\hline Но & $3.36 \mathrm{E}-09$ & $6.45 \mathrm{E}-07$ \\
\hline Er & $1.61 \mathrm{E}-09$ & $3.08 \mathrm{E}-07$ \\
\hline Totals & $5.21 \mathrm{E}-03$ & $1.00 \mathrm{E}+00$ \\
\hline
\end{tabular}


The data of Table 1 have been rearranged in order of decreasing fission product yield. Table 2-2 shows the 30 elements with the highest yields. Their sum is 0.99977 of all fission products. The Gibbs free energy of oxide formation $\Delta \mathrm{G}_{\mathrm{f}}{ }^{\mathrm{o}}$ (oxide) is an indicator of the element's tendency to consume oxygen. The values of Gibbs energies of oxide formation (per g-atom oxygen) for $\mathrm{U}, \mathrm{Pu}, \mathrm{Si}, \mathrm{C}$, and 24 fission products are shown vs. temperature in Figure 2-2. The anticipated chemical behaviors of various elements are discussed in Appendix A. Elements with large negative values of Gibbs energies of formation, such as $\mathrm{Y}$ and $\mathrm{Gd}$, form the most stable oxides. Of the elements shown in Figure 2, the following bind oxygen more strongly than carbon does at $1300 \mathrm{~K}: \mathrm{Y}, \mathrm{Gd}, \mathrm{Pr}, \mathrm{Sm}, \mathrm{La}, \mathrm{Ce}, \mathrm{Nd}, \mathrm{Eu}, \mathrm{Nb}, \mathrm{Ba}$, $\mathrm{Zr}, \mathrm{U}, \mathrm{Sr}, \mathrm{Pu}$, and Si. These elements can help bind free oxygen and prevent $\mathrm{CO}$ formation.

Table 2-2. Summary of anticipated oxide formation. Yields shown are for a case with $\mathrm{b}=66 \mathrm{MWd} / \mathrm{kg}, \mathrm{e}=10 \% . \Delta \mathrm{G}_{\mathrm{f}}{ }^{\mathrm{o}}$ values are computed by HSC.

\begin{tabular}{|c|c|c|c|c|c|}
\hline Element & $\begin{array}{c}\text { Yield } \\
\text { fraction }\end{array}$ & $\begin{array}{l}\text { Main } \\
\text { oxide }\end{array}$ & $\begin{array}{c}\Delta \mathrm{G}_{\mathrm{f}}^{\mathrm{o}} \mathrm{KJ} \text { per } \\
\text { g-atom }(\mathrm{O}) \text { at } \\
1300 \mathrm{~K}\end{array}$ & & Remarks \\
\hline $\mathrm{Zr}$ & $1.386 \mathrm{E}-01$ & $\mathrm{ZrO}_{2}$ & -426.3 & 2 & Forms carbides and oxides. \\
\hline $\mathrm{Xe}$ & $1.335 \mathrm{E}-01$ & none & none & 0 & Noble gas, volatile. \\
\hline \multirow[b]{2}{*}{ Mo } & \multirow[b]{2}{*}{$1.147 \mathrm{E}-01$} & $\mathrm{MoO}_{2}$ & -177.3 & & \multirow{2}{*}{$\begin{array}{l}\text { Partly oxides, partly metallic. Equilibrium } \\
\text { depends on T. }\end{array}$} \\
\hline & & $\mathrm{MoO}_{3}$ & -144.4 & 0 to 3 & \\
\hline $\mathrm{Nd}$ & $8.606 \mathrm{E}-02$ & $\mathrm{Nd}_{2} \mathrm{O}_{3}$ & -480.7 & 1.5 & Strong affinity for oxygen. \\
\hline $\mathrm{Ru}$ & $7.368 \mathrm{E}-02$ & $\mathrm{RuO}_{2}$ & -46.6 & 0 & Metallic form. No oxygen binding \\
\hline $\mathrm{Cs}$ & $7.360 \mathrm{E}-02$ & $\mathrm{Cs}_{2} \mathrm{O}$ & -173.6 & 0 & Not present as oxide. \\
\hline $\mathrm{Ce}$ & $7.046 \mathrm{E}-02$ & $\mathrm{Ce}_{2} \mathrm{O}_{3}$ & -476.6 & 2 & Strong affinity for oxygen. \\
\hline $\mathrm{Sr}$ & $3.958 \mathrm{E}-02$ & $\mathrm{SrO}$ & -459.6 & 1 & Forms carbides and oxides. \\
\hline $\mathrm{Ba}$ & $3.476 \mathrm{E}-02$ & $\mathrm{BaO}$ & -426.6 & 1 & Forms carbides and oxides. \\
\hline $\mathrm{La}$ & $3.103 \mathrm{E}-02$ & $\mathrm{La}_{2} \mathrm{O}_{3}$ & -474.4 & 1.5 & Strong affinity for oxygen \\
\hline Tc & $2.913 \mathrm{E}-02$ & $\mathrm{Tc}_{2} \mathrm{O}_{7}$ & -54.7 & 3.5 & Boils at about $600 \mathrm{~K}$, volatile. \\
\hline $\mathrm{Pd}$ & $2.823 \mathrm{E}-02$ & $\mathrm{PdO}$ & 19.5 & 0 & Metallic form. No oxygen binding. \\
\hline $\operatorname{Pr}$ & $2.733 \mathrm{E}-02$ & $\mathrm{Pr}_{2} \mathrm{O}_{3}$ & -478.9 & 1.5 & Strong affinity for oxygen. \\
\hline $\mathrm{Y}$ & $2.036 \mathrm{E}-02$ & $\mathrm{Y}_{2} \mathrm{O}_{3}$ & -510.0 & 1.5 & Strong affinity for oxygen. \\
\hline $\mathrm{Kr}$ & $1.616 \mathrm{E}-02$ & none & none & 0 & Noble gas, volatile. \\
\hline $\mathrm{Rh}$ & $1.540 \mathrm{E}-02$ & $\mathrm{Rh}_{2} \mathrm{O}_{3}$ & -8.7 & 0 & Metallic form. No oxygen binding \\
\hline $\mathrm{Rb}$ & $1.492 \mathrm{E}-02$ & $\mathrm{Rb}_{2} \mathrm{O}$ & -178.3 & 0 & Metallic form. No oxygen binding \\
\hline $\mathrm{Sm}$ & $1.408 \mathrm{E}-02$ & $\mathrm{Sm}_{2} \mathrm{O}_{3}$ & -482.1 & 1.5 & Strong affinity for oxygen. \\
\hline $\mathrm{Te}$ & $1.161 \mathrm{E}-02$ & $\mathrm{Te}_{2}$ & -45.9 & 0 & Jo oxygen binding. Metal or chalcogenide. \\
\hline $\mathrm{Pm}$ & $6.155 \mathrm{E}-03$ & $\mathrm{Pm}_{2} \mathrm{O}_{3}$ & Unknown & 1.5 & $\begin{array}{c}\text { Expected strong affinity for oxygen. Data } \\
\text { lacking }\end{array}$ \\
\hline $\mathrm{I}$ & $5.906 \mathrm{E}-03$ & & none & 0 & No oxygen binding. Volatile halide. \\
\hline $\mathrm{Eu}$ & $2.672 \mathrm{E}-03$ & $\mathrm{Eu}_{2} \mathrm{O}_{3}$ & -422.0 & 1.5 & Strong affinity for oxygen. \\
\hline $\mathrm{Se}$ & $2.466 \mathrm{E}-03$ & $\mathrm{SeO}_{2}$ & 4.1 & 0 & Jo oxygen binding. Metal or chalcogenide. \\
\hline $\mathrm{Ag}$ & $2.008 \mathrm{E}-03$ & & none & 0 & Metallic form. No oxygen binding. \\
\hline $\mathrm{Nb}$ & $1.894 \mathrm{E}-03$ & $\mathrm{Nb}_{2} \mathrm{O}_{5}$ & -288.4 & 2.5 & Strong affinity for oxygen. \\
\hline $\mathrm{Cd}$ & $1.630 \mathrm{E}-03$ & $\mathrm{CdO}$ & -126.1 & 0 & No oxygen binding. Metallic form. \\
\hline $\mathrm{Sn}$ & $1.400 \mathrm{E}-03$ & $\mathrm{SnO}_{2}$ & -152.6 & 2 & Some oxygen binding at low temperatures. \\
\hline $\mathrm{Br}$ & $9.733 \mathrm{E}-04$ & & none & 0 & No oxygen binding. Volatile halide. \\
\hline $\mathrm{Gd}$ & $9.019 \mathrm{E}-04$ & $\mathrm{Gd}_{2} \mathrm{O}_{3}$ & -481.1 & 1.5 & Strong affinity for oxygen. \\
\hline $\mathrm{Sb}$ & $5.339 \mathrm{E}-04$ & $\mathrm{Sb}_{2} \mathrm{O}_{3}$ & -125.5 & 1.5 & $\begin{array}{l}\text { Affinity for oxygen at lower } \\
\text { temperatures. }\end{array}$ \\
\hline
\end{tabular}




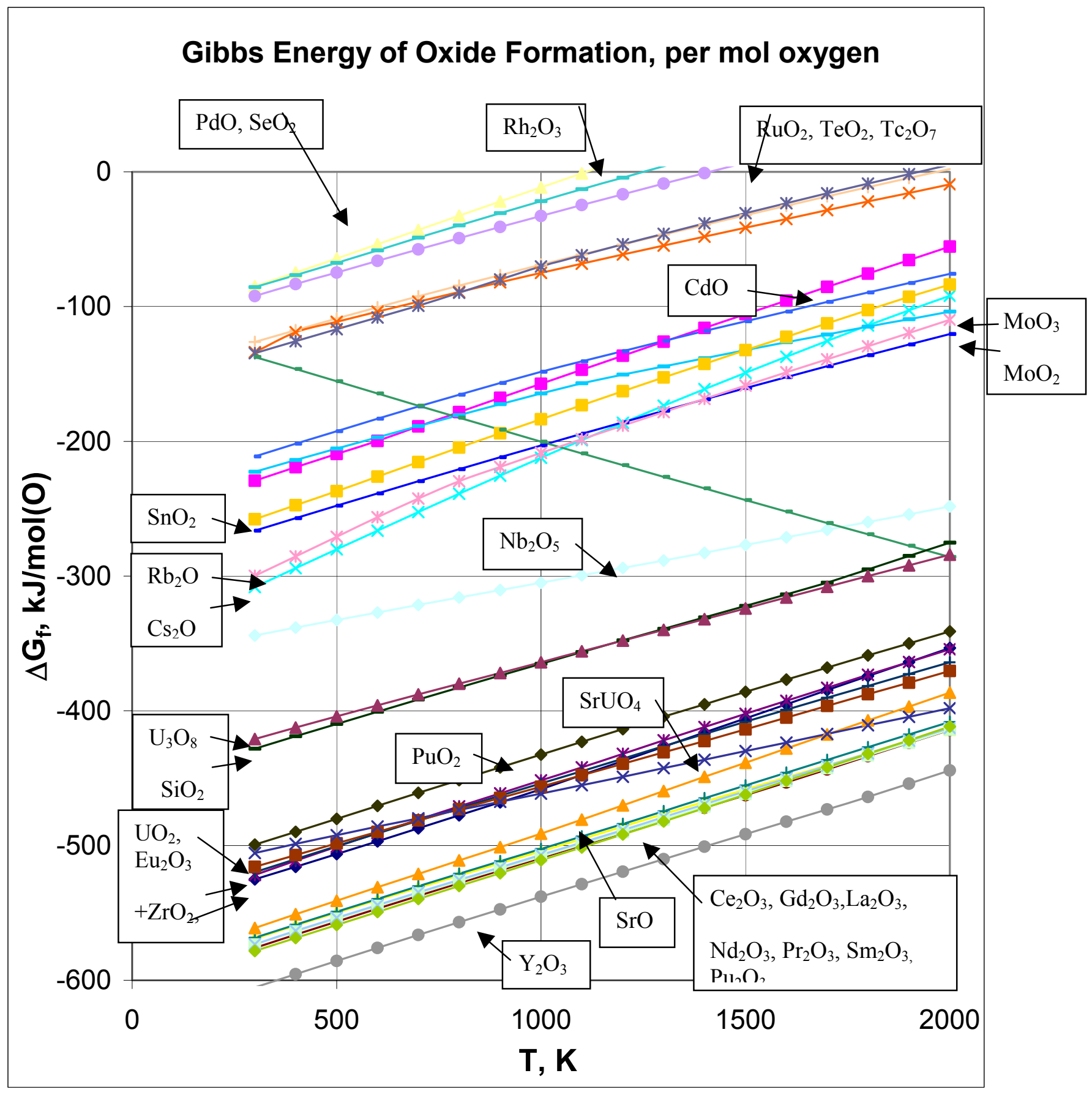

Figure 2-2. Gibbs energies of oxide formation (per g-atom of oxygen) of $\mathrm{U}, \mathrm{Pu}, \mathrm{Si}$, carbon, and 24 fission products computed with the HSC code. 
Since most of the uranium is ${ }^{238} \mathrm{U}$, substantial quantities of plutonium are bred in the fuel. Table 2-3 shows the growth of total plutonium in the fuel with burnup for various enrichments. For example, at $\mathrm{e}=$ $10 \%$ and $\mathrm{b}=97 \mathrm{MWd} / \mathrm{kg}$, there is $8.07 \times 10^{-4} \mathrm{~mol}(\mathrm{Pu})$ per fuel pebble. At low enrichments, burnup values $>81 \mathrm{MWd} / \mathrm{kg}$ were not calculated, because those cases would be subcritical.

Table 2-3. Total plutonium content in fuel ( $\mathrm{mol} \mathrm{Pu} /$ fuel pebble) vs. burnup. (Based on results of Weaver 2001). To get $\mathrm{mol}(\mathrm{Pu}) / \mathrm{gram}(\mathrm{U})$, divide by 9 .

\begin{tabular}{|c|c|c|c|c|c|}
\hline & $\mathrm{e}=7 \%$ & $8 \%$ & $10 \%$ & $15 \%$ & $20 \%$ \\
\hline Burnup & \multicolumn{5}{|c|}{$\mathrm{mol}(\mathrm{Pu}) /$ pebble } \\
\hline 0.0 & $0.000 \mathrm{E}+00$ & $0.000 \mathrm{E}+00$ & $0.000 \mathrm{E}+00$ & $0.000 \mathrm{E}+00$ & $0.000 \mathrm{E}+00$ \\
\hline 0.3 & $1.713 \mathrm{E}-06$ & $1.658 \mathrm{E}-06$ & $1.543 \mathrm{E}-06$ & $1.396 \mathrm{E}-06$ & $1.265 \mathrm{E}-06$ \\
\hline 2.9 & $4.931 \mathrm{E}-05$ & $4.821 \mathrm{E}-05$ & $4.551 \mathrm{E}-05$ & $4.113 \mathrm{E}-05$ & $3.757 \mathrm{E}-05$ \\
\hline 5.5 & $9.550 \mathrm{E}-05$ & $9.305 \mathrm{E}-05$ & $8.907 \mathrm{E}-05$ & $8.093 \mathrm{E}-05$ & $7.478 \mathrm{E}-05$ \\
\hline 8.1 & $1.382 \mathrm{E}-04$ & $1.352 \mathrm{E}-04$ & $1.302 \mathrm{E}-04$ & $1.194 \mathrm{E}-04$ & $1.105 \mathrm{E}-04$ \\
\hline 10.7 & $1.778 \mathrm{E}-04$ & $1.747 \mathrm{E}-04$ & $1.687 \mathrm{E}-04$ & $1.565 \mathrm{E}-04$ & $1.453 \mathrm{E}-04$ \\
\hline 13.3 & $2.141 \mathrm{E}-04$ & $2.115 \mathrm{E}-04$ & $2.057 \mathrm{E}-04$ & $1.920 \mathrm{E}-04$ & $1.786 \mathrm{E}-04$ \\
\hline 18.6 & $2.810 \mathrm{E}-04$ & $2.780 \mathrm{E}-04$ & $2.731 \mathrm{E}-04$ & $2.587 \mathrm{E}-04$ & $2.428 \mathrm{E}-04$ \\
\hline 34.2 & $4.341 \mathrm{E}-04$ & $4.373 \mathrm{E}-04$ & 4.343E-04 & $4.295 \mathrm{E}-04$ & $4.087 \mathrm{E}-04$ \\
\hline 49.9 & $5.551 \mathrm{E}-04$ & $5.616 \mathrm{E}-04$ & $5.627 \mathrm{E}-04$ & $5.718 \mathrm{E}-04$ & $5.527 \mathrm{E}-04$ \\
\hline 65.6 & $6.355 \mathrm{E}-04$ & $6.517 \mathrm{E}-04$ & $6.636 \mathrm{E}-04$ & $6.877 \mathrm{E}-04$ & $6.731 \mathrm{E}-04$ \\
\hline 81.3 & $6.525 \mathrm{E}-04$ & 7.129E-04 & 7.403E-04 & $7.822 \mathrm{E}-04$ & $7.833 \mathrm{E}-04$ \\
\hline 96.9 & & & 7.992E-04 & $8.577 \mathrm{E}-04$ & $8.734 \mathrm{E}-04$ \\
\hline 112.6 & & & $8.065 \mathrm{E}-04$ & $9.152 \mathrm{E}-04$ & $9.474 \mathrm{E}-04$ \\
\hline 128.3 & & & & $9.629 \mathrm{E}-04$ & $1.011 \mathrm{E}-03$ \\
\hline 144.0 & & & & $9.958 \mathrm{E}-04$ & $1.057 \mathrm{E}-03$ \\
\hline 159.6 & & & & $1.002 \mathrm{E}-03$ & $1.091 \mathrm{E}-03$ \\
\hline 175.3 & & & & & $1.120 \mathrm{E}-03$ \\
\hline 191.0 & & & & & $1.141 \mathrm{E}-03$ \\
\hline 200.0 & & & & & $1.154 \mathrm{E}-03$ \\
\hline
\end{tabular}

\subsection{Previous Results for NP-MHTGR}

The Gibbs energy of oxide formation does not provide a complete description, because there is competition from carbide formation. Chemical equilibria were examined for UCO fuels in the New Production Modular High Temperature Gas-Cooled Reactor (NP-MHTGR) program. The fuel is a mixture of $\mathrm{UO}_{2}, \mathrm{UC}_{2}$ and carbon (McCardell 1992). The reaction

$$
\text { Carbide }+\mathrm{O}_{2}<---->\text { Oxide }+ \text { Graphite }
$$


is pertinent for estimating the chemical states present in the fuel kernel and buffer. The Gibbs free energy of this reaction is

$$
\Delta \mathrm{G}_{\text {reaction }}^{\mathrm{o}}=\Delta \mathrm{G}_{\text {oxide }}^{\mathrm{o}}-\Delta \mathrm{G}_{\text {carbide }}^{\mathrm{o}}=\mathrm{RT} \ln \mathrm{P}_{\mathrm{O} 2}
$$

where $\Delta \mathrm{G}_{\text {oxide }}^{\mathrm{o}}$ and $\Delta \mathrm{G}_{\text {carbide }}^{\mathrm{a}}$ are the Gibbs free energies for oxide formation (right side of equation) and carbide formation (left side of equation), $\mathrm{R}=8.314 \mathrm{~J} / \mathrm{mol}-\mathrm{K}, \mathrm{T}$ is the temperature $(\mathrm{K})$, and $\mathrm{P}_{\mathrm{O} 2}$ is the equilibrium oxygen pressure. The unit "mol" refers to Avogadro's number of molecules or atoms (also spelled "mole"). The term RT $\ln \mathrm{P}_{\mathrm{O} 2}$ is called the "chemical potential of oxygen" or "oxygen potential" (relative to the carbide). (Homan 1977) For greater precision, the solubilities of fission product oxides in $\mathrm{UO}_{2}$ could be considered, (Kleykamp 1993) but they were not included in the work by Homan (1977) cited here.

Large negative values of oxygen potential at a given temperature indicate that oxides tend to form instead of carbides. The variation of the oxygen potential with temperature for some elements of interest is shown in Figure 2-3. Y and the lanthanides ( $\mathrm{La}, \mathrm{Sm}, \mathrm{Nd}, \mathrm{Pr}, \mathrm{Ce} . .$.$) have strong oxygen potentials. The$ oxygen would not tend to bond to the carbon atoms if lanthanide elements were available, because the carbon-oxygen reaction has a comparatively weak oxygen potential (dashed curve of Figure 3 ). After the lanthanides have bound to oxygen, the next strongest oxygen potentials are those of uranium and plutonium (Figures 2-2 and 2-3). The reaction

$$
\mathrm{UC}_{2}+\mathrm{O}_{2} \rightarrow \mathrm{UO}_{2}+2 \mathrm{C}
$$

could occur until all the $\mathrm{UC}_{2}$ were consumed. The vapor pressure of $\mathrm{CO}$ can be estimated from the less probable reaction

$$
\mathrm{UO}_{2}+4 \mathrm{C} \rightarrow \mathrm{UC}_{2}+2 \mathrm{CO}
$$

For this reaction it was found that $\mathrm{p}(\mathrm{CO})=1.54 \times 10^{-6} \mathrm{~Pa}$ at $1000 \mathrm{~K}$ and $\mathrm{p}(\mathrm{CO})=2.03 \mathrm{kPa}$ at $1800 \mathrm{~K}$ (Czechowicz, 1992). These low pressures indicate that formation of $\mathrm{CO}$ from $\mathrm{UO}_{2}$ via reaction (4) is not significant in this temperature range, because the oxygen potential of uranium is much stronger than the oxygen potential of carbon. 


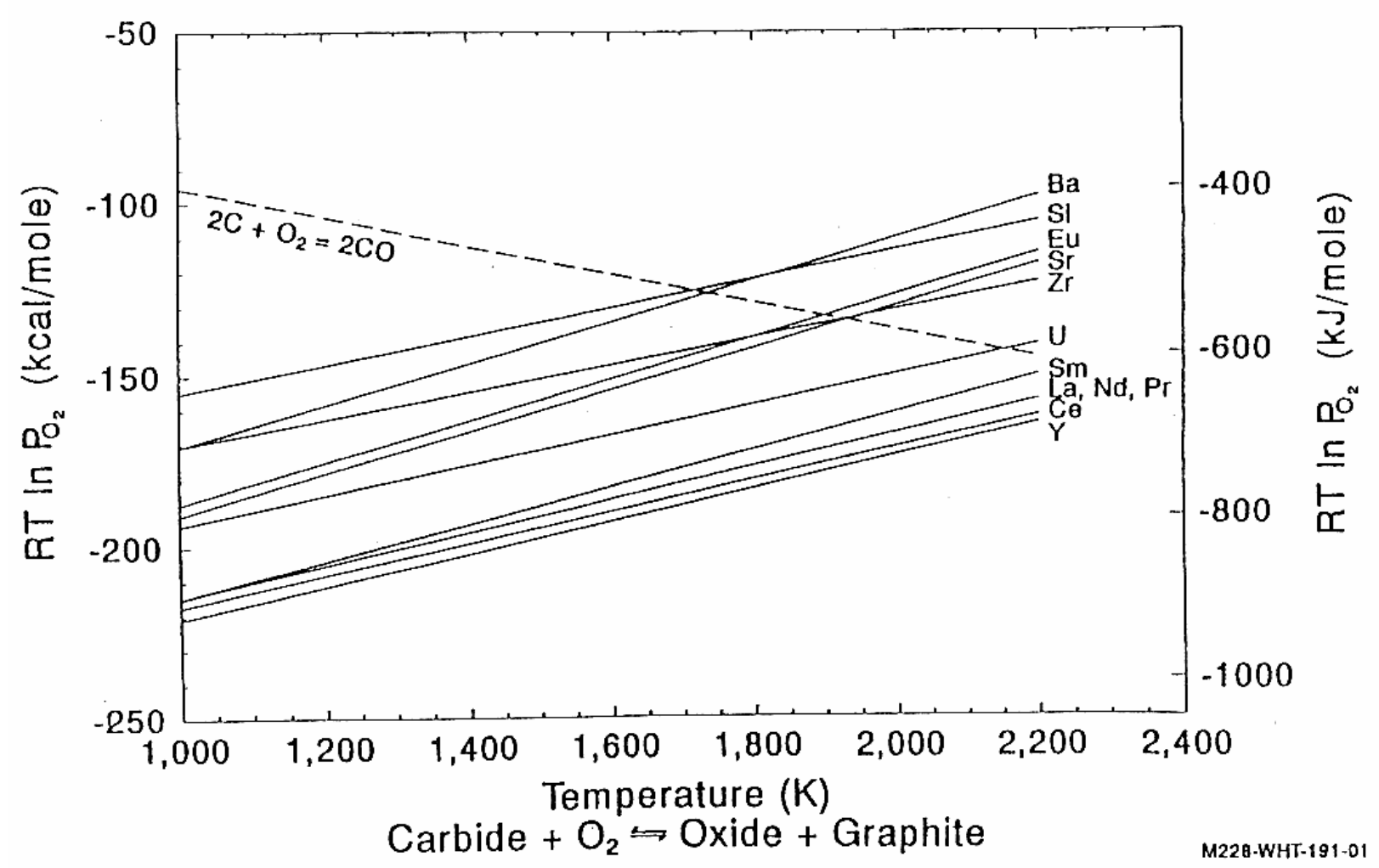

Figure 2-3. Oxygen potential of various elements vs. temperature ( McCardell 1992). Elements with large negative oxygen potentials form the most stable oxides.

The oxygen potential for

$$
2 \mathrm{C}+\mathrm{O}_{2} \rightarrow 2 \mathrm{CO}
$$

is weak (dashed curve of Figure 2-3), so the equilibrium vapor pressure of $\mathrm{CO}$ from this reaction will also be very low at $\mathrm{T}<1700 \mathrm{~K}$.

When all the $\mathrm{UC}_{2}$ has been oxidized to $\mathrm{UO}_{2}$, then some of the remaining oxygen can bind to $\mathrm{Zr}, \mathrm{Sr}, \mathrm{Eu}$, and $\mathrm{Ba}$ by reactions such as

$$
\mathrm{BaC}_{2}+\mathrm{O} \rightarrow \mathrm{BaO}+2 \mathrm{C}
$$

To prevent excess oxygen from forming CO, Czechowicz (1992) estimated that the initial carbon content of the fuel must exceed 15.6 mole $\%$ of $\mathrm{UC}_{2}$. 


\subsection{Oxygen Balance}

A qualitative picture of equilibrium oxygen behavior is given by Homan (1977), Czechowicz (1992), and McCardell (1992). Here we consider the yields for the example case with $\mathrm{e}=10 \%$ and burnup $=66$ $\mathrm{MWd} / \mathrm{kg}$.

1. Yttrium and the lanthanides ( $\mathrm{La}, \mathrm{Ce}, \mathrm{Pr}, \mathrm{Nd}, \mathrm{Pm}, \mathrm{Sm}, \mathrm{Gd} . .$.$) have very strong affinities for oxygen$ (Figure 3), so they will immediately bind about 1.5 oxygen atoms each to form compounds like $\mathrm{Y}_{2} \mathrm{O}_{3}$. (An exception is Eu, which behaves more like Ba and Sr.) Since the total yield of these elements (excluding $\mathrm{Eu}$ ) is $25.64 \%$ of the fission products, with two fission products per fission, and each atom binds 1.5 oxygen atoms, these elements will bind about 0.769 oxygen atoms per fission.

2. Next up the scale of Figure 3 is uranium. After the lanthanides have been oxidized, uranium carbide will be oxidized by the reaction

$$
\mathrm{UC}_{2}+\mathrm{O}_{2}->\mathrm{UO}_{2}+2 \mathrm{C}
$$

as long as $\mathrm{UC}_{2}$ exists. Plutonium can also bind oxygen strongly (Figure 2).

3. As the $\mathrm{UC}_{2}$ is consumed, $\mathrm{Zr}, \mathrm{Sr}, \mathrm{Ba}$, and Eu will be the next to become oxidized. Their fission product yields are $0.139\left(\mathrm{Zr} \rightarrow \mathrm{ZrO}_{2}\right), 0.0396(\mathrm{Sr} \rightarrow \mathrm{SrO}), 0.0348(\mathrm{Ba} \rightarrow \mathrm{BaO})$, and $0.00267\left(\mathrm{Eu} \rightarrow \mathrm{Eu}_{2} \mathrm{O}_{3}\right)$. Taking into account the number of oxygen atoms bound per fission product atom, and multiplying by 2 fission products per fission, these elements could bind up to 0.713 oxygen atoms per fission.

4. Finally, if these elements have been oxidized and there is still more oxygen available, some carbon may be oxidized to form $\mathrm{CO}$ :

$$
\mathrm{C}+\mathrm{O}-\rightarrow \mathrm{CO}
$$

$\mathrm{CO}$ formation could produce high internal pressures and endanger the integrity of the TRISO fuel particles, so it is desirable to avoid this reaction. It can be avoided by having plenty of $\mathrm{UC}_{2}$ in the fuel initially. Oxygen and CO may also increase the rate at which the fuel kernel migrates into the buffer region in a strong temperature gradient, called the "amoeba effect." (Wagner-Löffler 1973 and 1977) The amoeba effect can be prevented by the addition of sufficient amounts of oxygen getters, such as $\mathrm{UC}_{2}$ or $\mathrm{SiC}$, to the fuel. (Sayers et al. 1973) Experimental measurements of TRISO fuel particles from the Dragon reactor showed that fractions on the order of $0.1-10 \%$ of the $\mathrm{CO}$ gas formed (according to 
equilibrium calculations) could be released from the fuel particle after irradiation on times scales of thousands of seconds. (Strigl 1977) These low loss rates would probably not have significant impacts on internal CO pressures.

\subsubsection{Need for Oxygen}

If the fuel were only $\mathrm{UC}_{2}$, then the Lanthanide elements would not be oxidized. They could migrate to the $\mathrm{SiC}$ layer and cause its erosion. In order to prevent this, there should be sufficient oxygen in the fuel.

There will be a mixture of phases present in the fuel particles, such as $\mathrm{UO}_{2}, \mathrm{UC}_{1.92} \mathrm{O}_{0.08}$, and perhaps $\mathrm{UC}_{0.89} \mathrm{O}_{0.11}$. (Page A-2 of McCardell et al. 1992) For an example calculation we assume that the fuel is comprised of $\mathrm{UO}_{2}$ and $\mathrm{UC}_{1.92} \mathrm{O}_{0.08}$. Let $\mathrm{c}$ be the fraction of $\mathrm{UC}_{1.92} \mathrm{O}_{0.08}$ in the fuel. Then (1-c) is the fraction of $\mathrm{UO}_{2}$. We require that

(1-c)(2 oxygen atoms liberated per fission of $\left.\mathrm{UO}_{2}\right)$

$+\mathrm{c}\left(0.08\right.$ oxygen atoms liberated per fission of $\left.\mathrm{UC}_{1.92} \mathrm{O}_{0.08}\right)$

$>$ (number of oxygen atoms needed to oxidize $\mathrm{Y}+$ Lanthanides per fission),

from which

$$
[2(1-c)+0.08 c]>0.769
$$

and $\mathrm{c}_{\max }=0.64$. If we assumed that the fuel were $\mathrm{UO}_{2}$ and pure $\mathrm{UC}_{2}$, then we would find $\mathrm{c}_{\max }=0.62$. Homan (1977) recommends $35 \% \pm 20 \%$ as an optimum value of $\mathrm{c}$. This is consistent with the minimum fraction $15.6 \%$ of the CEGA Fuel Product Specification (Czechowicz 1992). Thus, if the $\mathrm{UC}_{2}$ content is kept within this range, it is unlikely that high pressures of CO would be generated in the UCO fuel or that the Lanthanides could easily migrate to attack the SiC layer. However, we will see later that even $\mathrm{UC}_{2}$ concentrations below 15\% may provide significant benefits in reduction of $\mathrm{CO}$ gas production.

\subsubsection{Equilibrium Calculations}


The HSC and FACTSAGE codes were compared, and the HSC code was chosen for these computations. This comparison and some suggestions for HSC use are given in Appendix B.

The input values of fission products were calculated at specified numbers of days (Table 2-4). The exact values of burnup $(\mathrm{MWd} / \mathrm{kg}$ ) were used in calculations, but they are represented by integers in the text.

Table 2-4. Relation between burnup and time.

\begin{tabular}{|c|c|c|c|}
\hline Time, days & $\begin{array}{c}\text { Burnup, } \\
\text { MWd/kg }\end{array}$ & $\begin{array}{c}\text { Integer } \\
\text { Representation }\end{array}$ & $\begin{array}{l}\text { Atomic } \\
\text { burnup }\end{array}$ \\
\hline 3 & 0.261 & none & 2.80 E-04 \\
\hline 33 & 2.874 & 3 & 0.00311 \\
\hline 63 & 5.487 & 5 & 0.00592 \\
\hline 93 & 8.099 & 8 & 0.00873 \\
\hline 123 & 10.712 & 11 & 0.01155 \\
\hline 153 & 13.325 & 13 & 0.01433 \\
\hline 213 & 18.550 & 19 & 0.01994 \\
\hline 393 & 34.226 & 34 & 0.03658 \\
\hline 573 & 49.902 & 50 & 0.05311 \\
\hline 753 & 65.578 & 66 & 0.06972 \\
\hline 933 & 81.254 & 81 & 0.08614 \\
\hline 1113 & 96.930 & 97 & 0.10263 \\
\hline 1293 & 112.606 & 113 & 0.11890 \\
\hline 1473 & 128.282 & 128 & 0.13524 \\
\hline 1653 & 143.959 & 144 & 0.15142 \\
\hline 1833 & 159.635 & 160 & 0.16769 \\
\hline 2013 & 175.311 & 175 & 0.18378 \\
\hline 2193 & 190.987 & 191 & 0.19976 \\
\hline
\end{tabular}

The 17 input quantities used in $\mathrm{HSC}$ calculations were $\mathrm{UO}_{2}, \mathrm{UC}_{2}, \mathrm{Pu}, \mathrm{O}_{2}, \mathrm{C}$ and 12 fission product groups, as illustrated in Table 2-5. These data were entered into HSC in five phases: gases, iodides, oxides, carbides, and other substances. HSC assumes that the iodides, oxides, carbides, and other substances are in solid solution, unless the user specifies otherwise. In order to see whether this default condition caused errors in the results, we also ran HSC listing the oxides and other substances both in solution and as separate solid phases. The results were identical with the corresponding previous run. 
The fission product equilibria were computed for wide ranges of parameter values, as shown in Table 2-6. The temperature range includes all temperatures that the fuel might encounter, from room temperature up to $2000 \mathrm{~K}$, which is near the peak anticipated for pebble-bed fuel during an accident. (Lake 2002) The quantities of 241 possible product substances were computed at each temperature. Additional studies were done to quantify the variation of $\mathrm{CO}$ yield with $\mathrm{UC}_{2}$ fraction in the regions $\mathrm{c}=0-10 \%$ and $80-100 \%$, and at higher burnup, up to $191 \mathrm{MWd} / \mathrm{kg}$. Altogether about 4600 equilibria were computed and compiled in a database. The equilibrium data of the most abundant substances are shown in Table 2-7 for an example case with high burnup. As the temperature increases, zirconium and barium remain mostly as carbides throughout the temperature region 500-2000 K, but transitions are apparent for some other elements. Kleykamp (1993) found that $\mathrm{LaO}_{2}, \mathrm{YO}_{2}, \mathrm{CeO}_{2}, \mathrm{PrO}_{2}, \mathrm{NdO}_{2}$ and $\mathrm{SrO}$ have high solubilities in $\mathrm{UO}_{2}$, but that $\mathrm{Rb}, \mathrm{Cs}, \mathrm{Ba}, \mathrm{Mo}, \mathrm{Te}$ and their oxides have very low solubilities. From Table 2-7, as the temperature increases from 600 to $700 \mathrm{~K} \mathrm{SrUO}_{4}$ replaces $\mathrm{SrO}$ as the dominant oxide of strontium. At 600 $\mathrm{K}$ ruthenium is mainly bound as $\mathrm{URu}_{3}$, but at $\mathrm{T}>700 \mathrm{~K}$ ruthenium metal becomes the dominant form of $\mathrm{Ru}$. As temperature increases above $1500 \mathrm{~K}$ (boldfaced in table), $\mathrm{LaC}_{2}$ gradually replaces $\mathrm{La}_{2} \mathrm{O}_{3}$ as the dominant lanthanum compound, so less oxygen is bound by La. The ratio of oxygen bound by La at 2000 $\mathrm{K}$ to that bound at $1200 \mathrm{~K}$ is 0.26 . This means that estimates of $\mathrm{CO}$ formation assuming oxygen to be firmly bound by La may become erroneous at high temperatures, and that the actual CO yield could exceed simplified estimates. 
Table 2-5. Input data for a case with e $=10 \%, c=30 \%$. Quantities are mol per fuel pebble. (To get mol/gram (U), divide by 9.)

\begin{tabular}{|c|c|c|c|c|c|c|c|}
\hline Burnup (MWd/kg) & 18.55 & 34.23 & 49.90 & 65.58 & 81.25 & 96.93 & 112.61 \\
\hline Total Days & 213 & 393 & 573 & 753 & 933 & 1113 & 1293 \\
\hline \multicolumn{8}{|l|}{12 Fission Product Groups } \\
\hline $\mathrm{Ba}$ & $5.49 \mathrm{E}-05$ & $9.68 \mathrm{E}-05$ & $1.39 \mathrm{E}-04$ & $1.81 \mathrm{E}-04$ & $2.24 \mathrm{E}-04$ & $2.68 \mathrm{E}-04$ & $3.13 \mathrm{E}-04$ \\
\hline$\overline{C s+R b+R h}$ & $1.53 \mathrm{E}-04$ & $2.87 \mathrm{E}-04$ & $4.17 \mathrm{E}-04$ & $5.41 \mathrm{E}-04$ & $6.61 \mathrm{E}-04$ & $7.76 \mathrm{E}-04$ & 8.84E-04 \\
\hline $\mathrm{I}+\mathrm{Br}$ & $1.03 \mathrm{E}-05$ & $1.85 \mathrm{E}-05$ & $2.71 \mathrm{E}-05$ & $3.58 \mathrm{E}-05$ & $4.47 \mathrm{E}-05$ & $5.37 \mathrm{E}-05$ & $6.27 \mathrm{E}-05$ \\
\hline $\begin{array}{l}\mathrm{La}+\mathrm{Y}+\mathrm{Ce}+\mathrm{Pr}+\mathrm{Nd}+\mathrm{Pm}+\mathrm{Sm}+ \\
\mathrm{Eu}+\mathrm{Gd}+\mathrm{Nb}\end{array}$ & $4.10 \mathrm{E}-04$ & 7.36E-04 & $1.05 \mathrm{E}-03$ & $1.36 \mathrm{E}-03$ & 1.66E-03 & $1.96 \mathrm{E}-03$ & $2.25 \mathrm{E}-03$ \\
\hline Mo & $1.57 \mathrm{E}-04$ & $3.05 \mathrm{E}-04$ & $4.52 \mathrm{E}-04$ & $5.98 \mathrm{E}-04$ & $7.41 \mathrm{E}-04$ & $8.82 \mathrm{E}-04$ & $1.02 \mathrm{E}-03$ \\
\hline $\mathrm{Pd}+\mathrm{Ag}$ & $2.18 \mathrm{E}-05$ & $5.51 \mathrm{E}-05$ & $1.00 \mathrm{E}-04$ & $1.58 \mathrm{E}-04$ & $2.26 \mathrm{E}-04$ & $3.06 \mathrm{E}-04$ & $3.96 \mathrm{E}-04$ \\
\hline $\mathrm{Ru}+\mathrm{Tc}$ & 1.49E-04 & 2.74E-04 & 4.04E-04 & $5.36 \mathrm{E}-04$ & $6.70 \mathrm{E}-04$ & $8.08 \mathrm{E}-04$ & $9.48 \mathrm{E}-04$ \\
\hline $\mathrm{Sn}+\mathrm{Cd}+\mathrm{Sb}$ & $3.73 \mathrm{E}-06$ & $7.80 \mathrm{E}-06$ & $1.27 \mathrm{E}-05$ & $1.86 \mathrm{E}-05$ & $2.54 \mathrm{E}-05$ & $3.35 \mathrm{E}-05$ & $4.27 \mathrm{E}-05$ \\
\hline $\mathrm{Sr}$ & $7.63 \mathrm{E}-05$ & $1.24 \mathrm{E}-04$ & $1.67 \mathrm{E}-04$ & $2.06 \mathrm{E}-04$ & $2.42 \mathrm{E}-04$ & $2.74 \mathrm{E}-04$ & $3.04 \mathrm{E}-04$ \\
\hline $\mathrm{Te}+\mathrm{Se}$ & $2.06 \mathrm{E}-05$ & $3.78 \mathrm{E}-05$ & $5.55 \mathrm{E}-05$ & $7.33 \mathrm{E}-05$ & $9.14 \mathrm{E}-05$ & $1.10 \mathrm{E}-04$ & $1.28 \mathrm{E}-04$ \\
\hline $\mathrm{Xe}+\mathrm{Kr}$ & $2.25 \mathrm{E}-04$ & $4.11 \mathrm{E}-04$ & $5.96 \mathrm{E}-04$ & $7.80 \mathrm{E}-04$ & $9.64 \mathrm{E}-04$ & $1.15 \mathrm{E}-03$ & $1.33 \mathrm{E}-03$ \\
\hline$\overline{\mathrm{Zr}}$ & $2.27 \mathrm{E}-04$ & $4.01 \mathrm{E}-04$ & $5.66 \mathrm{E}-04$ & $7.22 \mathrm{E}-04$ & $8.71 \mathrm{E}-04$ & $1.01 \mathrm{E}-03$ & $1.15 \mathrm{E}-03$ \\
\hline \multicolumn{8}{|l|}{ Other Substances } \\
\hline $\mathrm{O}_{2}$ from $\mathrm{UO}_{2}$ & $5.28 \mathrm{E}-04$ & $9.64 \mathrm{E}-04$ & $1.40 \mathrm{E}-03$ & $1.82 \mathrm{E}-03$ & $2.25 \mathrm{E}-03$ & $2.67 \mathrm{E}-03$ & $3.09 \mathrm{E}-03$ \\
\hline C from $\mathrm{UC}_{2}+$ buffer & $1.33 \mathrm{E}-01$ & $1.34 \mathrm{E}-01$ & $1.34 \mathrm{E}-01$ & $1.35 \mathrm{E}-01$ & $1.35 \mathrm{E}-01$ & $1.35 \mathrm{E}-01$ & $1.36 \mathrm{E}-01$ \\
\hline $\mathrm{UC}_{2}$ left & $1.11 \mathrm{E}-02$ & $1.09 \mathrm{E}-02$ & $1.08 \mathrm{E}-02$ & $1.06 \mathrm{E}-02$ & $1.04 \mathrm{E}-02$ & $1.02 \mathrm{E}-02$ & $1.00 \mathrm{E}-02$ \\
\hline $\mathrm{UO}_{2}$ left & $2.60 \mathrm{E}-02$ & $2.55 \mathrm{E}-02$ & $2.51 \mathrm{E}-02$ & $2.47 \mathrm{E}-02$ & $2.43 \mathrm{E}-02$ & $2.38 \mathrm{E}-02$ & $2.34 \mathrm{E}-02$ \\
\hline$\overline{\mathrm{Pu}}$ & $2.73 \mathrm{E}-04$ & $4.34 \mathrm{E}-04$ & $5.63 \mathrm{E}-04$ & $6.64 \mathrm{E}-04$ & $7.40 \mathrm{E}-04$ & 7.99E-04 & $8.07 \mathrm{E}-04$ \\
\hline
\end{tabular}


Table 2-6. Parameter values used in HSC calculations. No computations were done for $\mathrm{b}>81 \mathrm{MWd} / \mathrm{kg}$ at $\mathrm{e}=7$ or $8 \%$, because $\mathrm{k}_{\mathrm{eff}}<1$ for those cases.

\begin{tabular}{|c|c|c|c|c|}
\hline \multirow{2}{*}{$\begin{array}{l}\mathrm{UC}_{2} \text { fraction } \\
\text { Temperature }\end{array}$} & \multirow{2}{*}{$\begin{array}{l}\mathrm{c} \\
\mathrm{T}\end{array}$} & \multirow{2}{*}{$\begin{array}{l}\% \\
\mathrm{~K}\end{array}$} & $\begin{array}{llllllll}0 & 10 & 20 & 30 & 40 & 50 & 60 & 70\end{array}$ & 8 values \\
\hline & & & $300-2000$ in steps of $100 \mathrm{~K}$ & 18 values \\
\hline & & & Burnup b, MWd/kg & \\
\hline Enrichment & $\mathrm{e}$ & $7 \%$ & $19,34,50,66,81$ & 5 values \\
\hline & & $8 \%$ & $19,34,50,66,81$ & 5 values \\
\hline & & $10 \%$ & $19,34,50,66,81,97,113$ & 7 values \\
\hline & & $15 \%$ & $19,34,50,66,81,97,113$ & 7 values \\
\hline & & $20 \%$ & $19,34,50,66,81,97,113$ & 7 values \\
\hline & & & Subtotal of enrichment/burnup combinations & 31 values \\
\hline & & & Total number $=8 * 18 * 31=$ & 4464 values \\
\hline
\end{tabular}




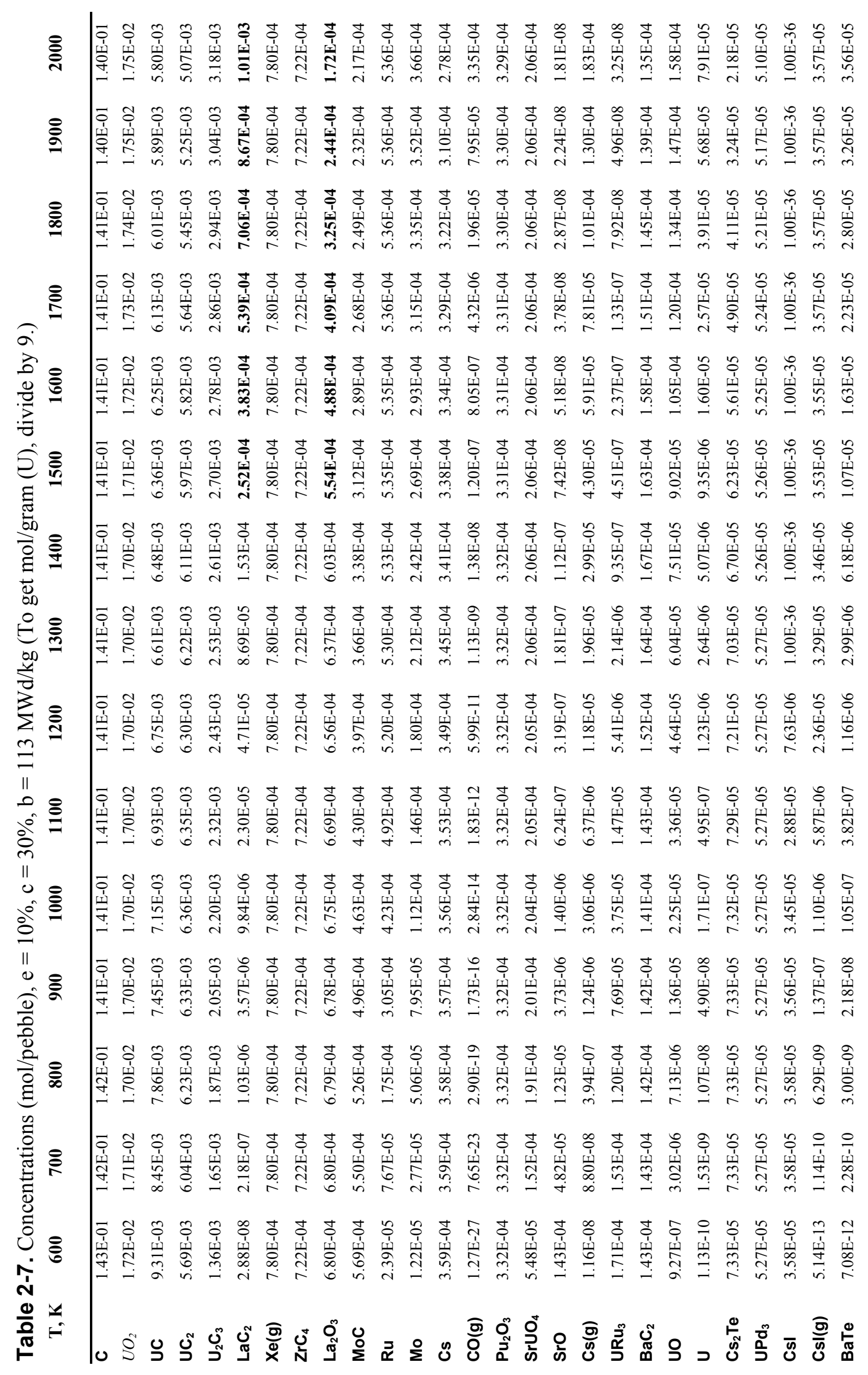




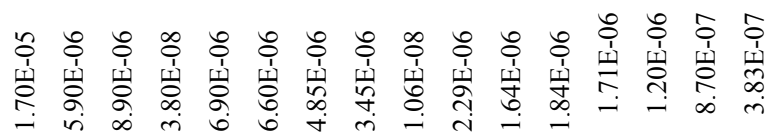

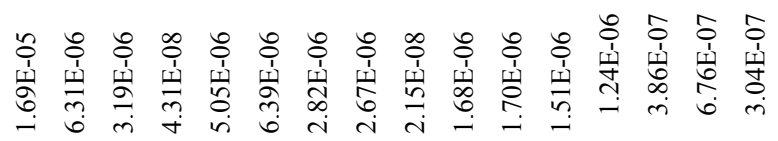

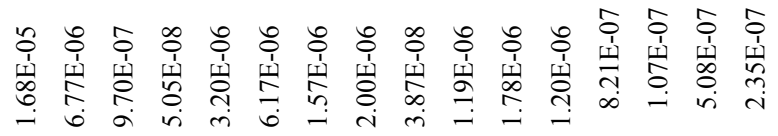

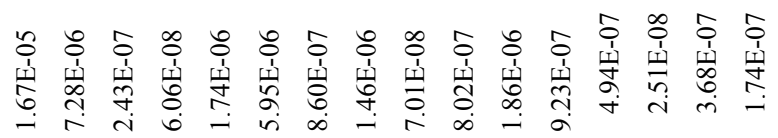

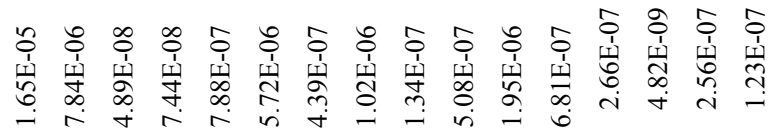

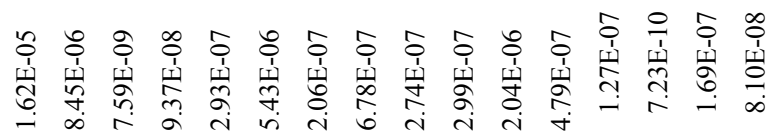

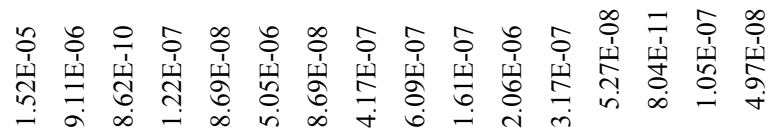

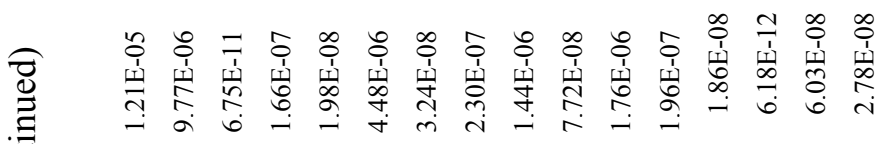

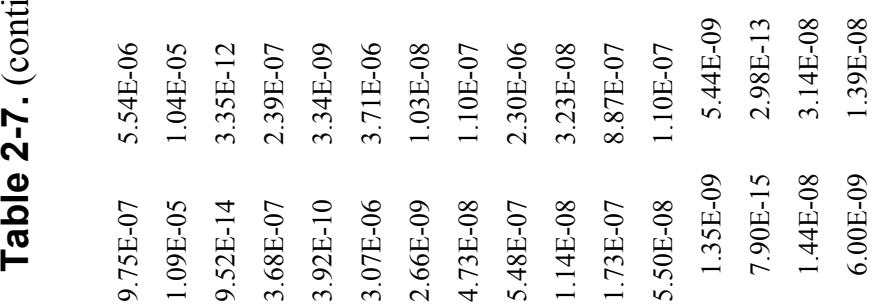

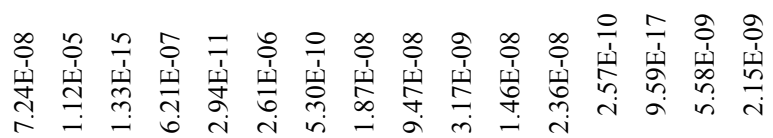

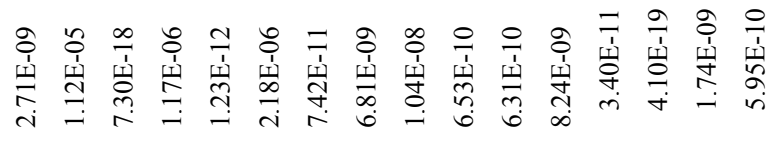

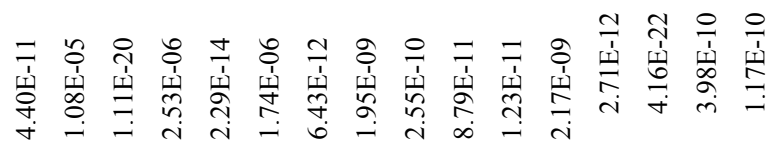

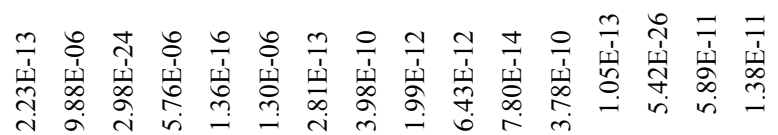

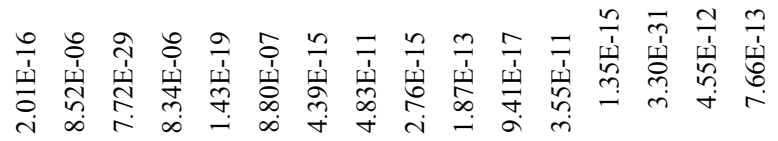
क 
For a case with fixed enrichment $\mathrm{e}=20 \%$ and $\mathrm{UC}_{2}$ fraction $\mathrm{c}=30 \%$, Figure $2-4$ shows the temperature variation of the $\mathrm{CO}$ yield in units of mol (CO) per gram (U). The high-burnup case yields higher $\mathrm{CO}$ concentration, as expected. However, if the $\mathrm{CO}$ yield is normalized to units of molecules $(\mathrm{CO})$ per fission, the burnup dependence is greatly reduced, as can be seen from the same three curves in Figure 25. The yield in mol/gram (U) is valid only for a specific fuel design, but the yield expressed in molecules/fission is more generic. Figure 2-6 shows the dependence of $\mathrm{CO}$ yield per gram (U) on burnup, at various temperatures. The yield goes to zero at zero burnup. When the yield is normalized to CO molecules per fission, as depicted in Figure 2-7, the curves are almost flat. These logarithmic curves do not show the details of the curve shapes. Figure 2-8 shows the yield per gram (U) vs. burnup on a linear scale. There is a slight upward curvature. Figure 2-9 shows that there is very little variation of CO yield with burnup when normalized to yield per fission. Even with no fissions, some of the $\mathrm{UO}_{2}$ could interact with $\mathrm{C}$ to generate $\mathrm{CO}$. At the lowest burnup calculated $(0.26 \mathrm{MWd} / \mathrm{kg})$ the yield appeared to jump to a higher value, but the HSC code had convergence difficulties for this case, so this point is in doubt, and it is not shown in the figures. In addition to variations with burnup and temperature, the CO yield also depends upon the $\mathrm{UC}_{2}$ fraction and enrichment of the fuel. 


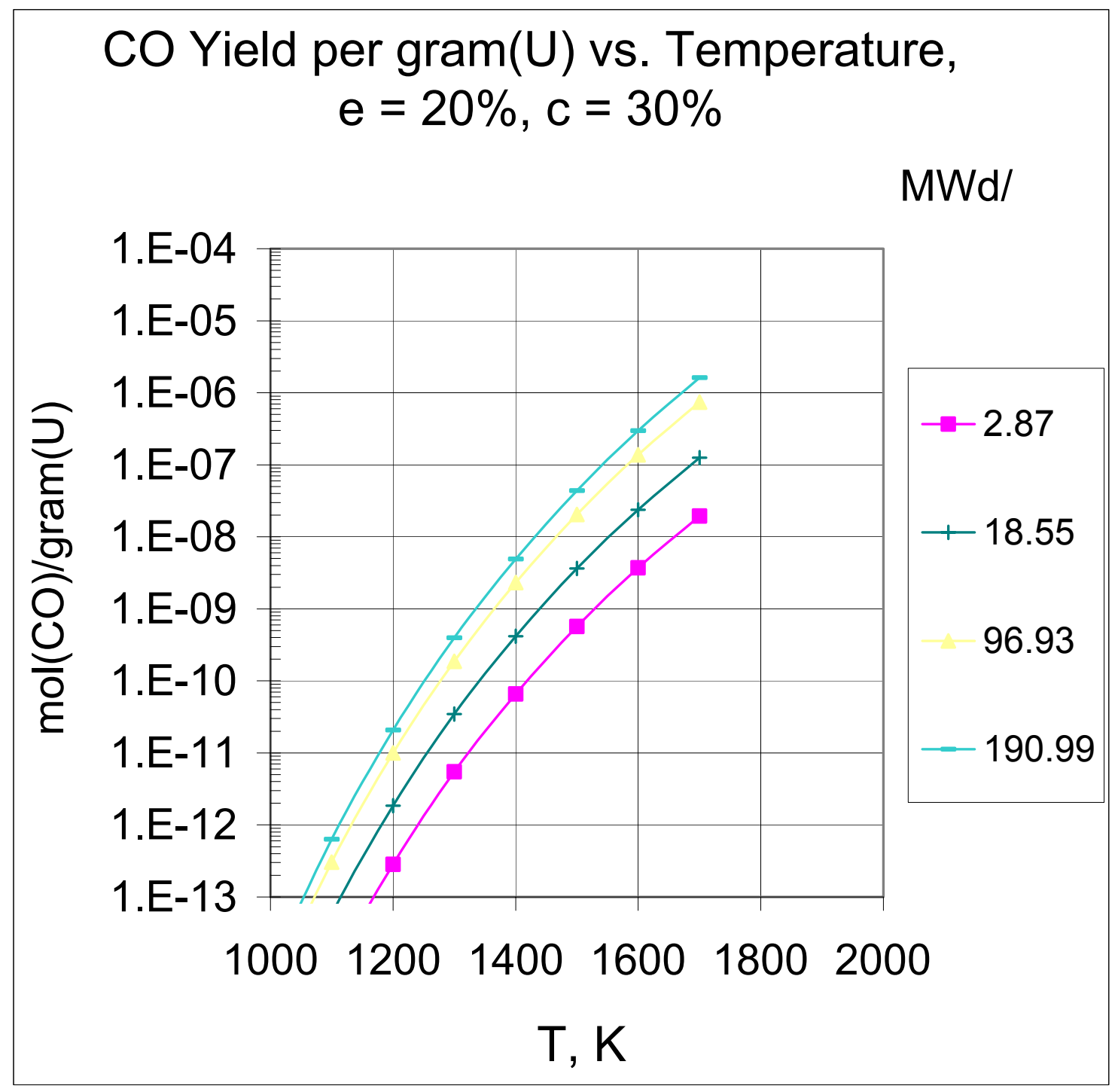

Figure 2-4. $\mathrm{CO}$ yield per gram $(\mathrm{U})$ vs. temperature at various burnup values for a case with $\mathrm{e}=20 \%, \mathrm{c}=$ $30 \%$. The CO yield per pebble is nine times larger. A burnup of $191 \mathrm{MWd} / \mathrm{kg}$ is equivalent to an atomic burnup of $20 \%$ (Table $2-4$ ). 


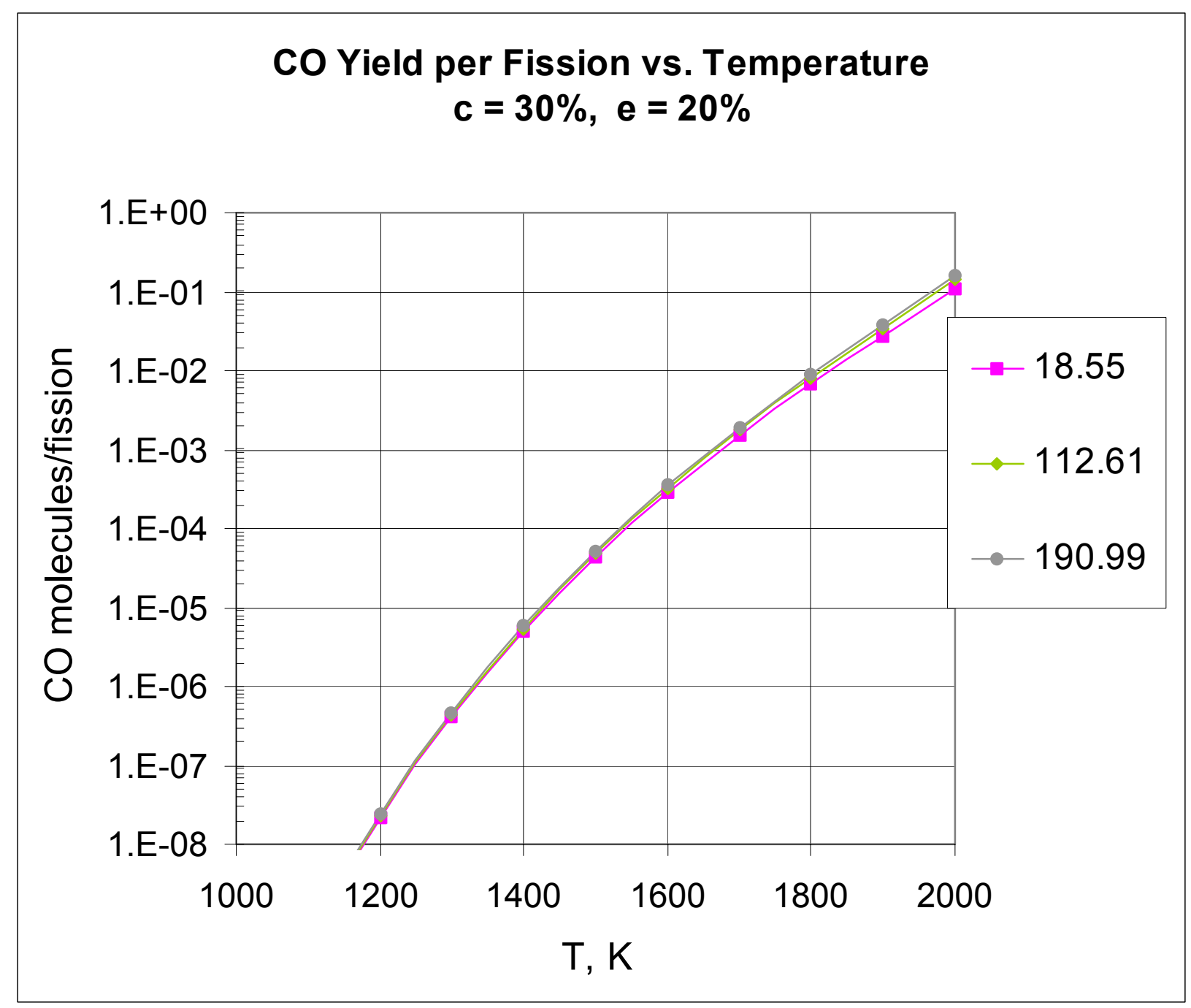

Figure 2-5. CO yield per fission vs. temperature at various values of burnup for a case with $\mathrm{e}=20 \%$, $\mathrm{c}=30 \%$. 


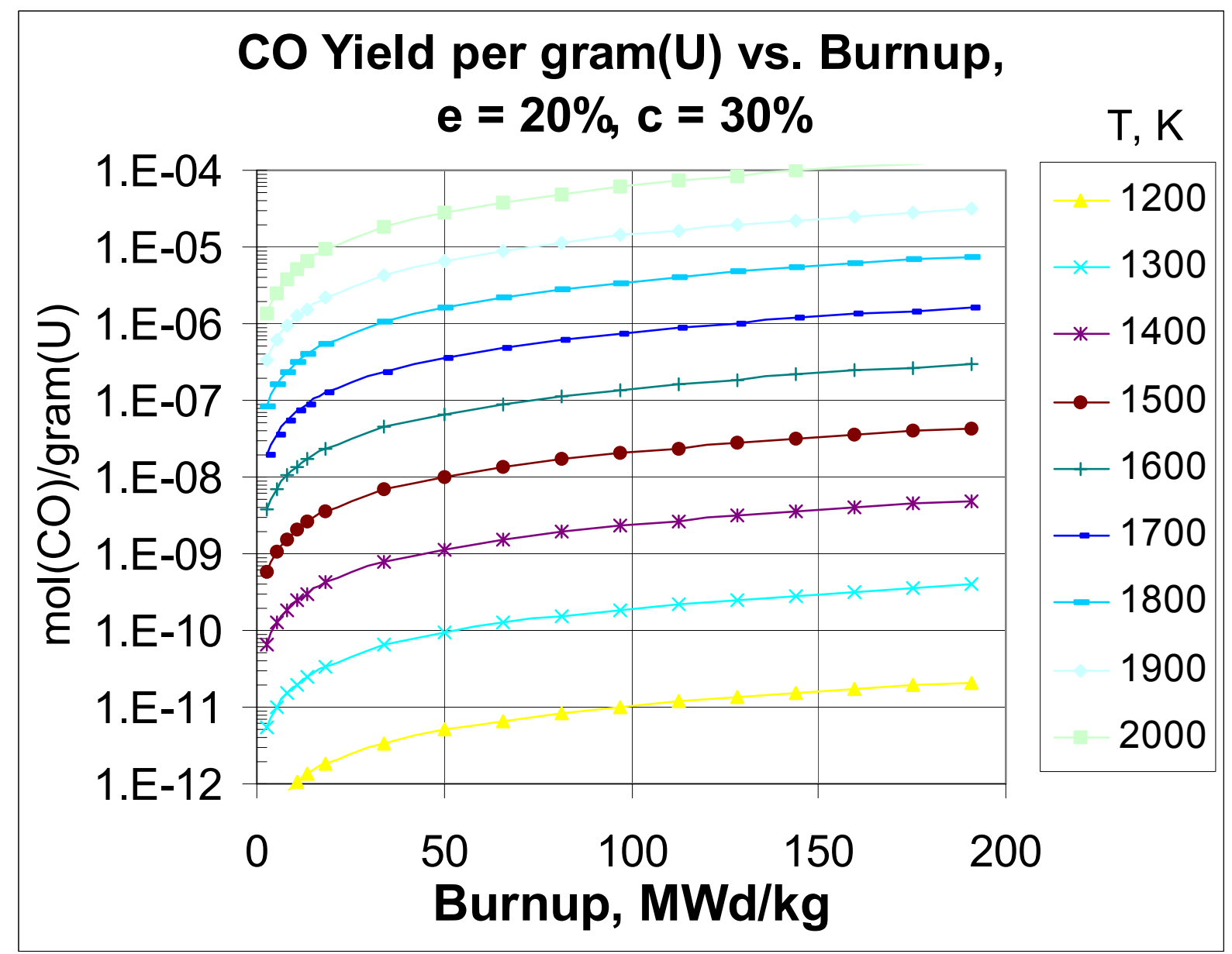

Figure 2-6. CO yield per gram(U) vs. burnup at various temperatures for a case with e $=20 \%, \mathrm{c}=30 \%$. The CO yield per pebble is nine times larger. A burnup of $191 \mathrm{MWd} / \mathrm{kg}$ is equivalent to an atomic burnup of $20 \%$ (Table $2-4$ ). 


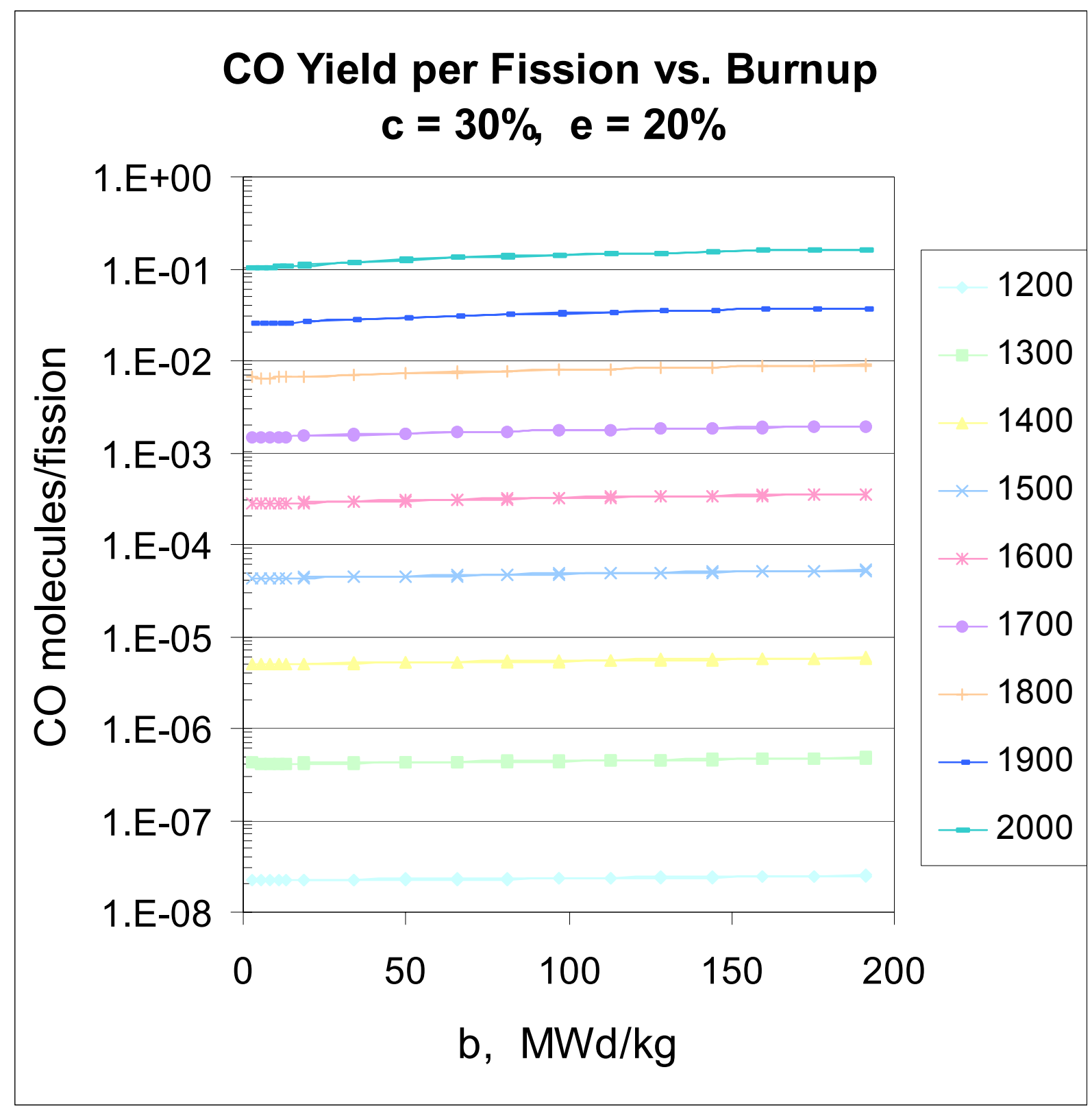

Figure 2-7. $\mathrm{CO}$ yield per fission vs. burnup at various temperatures, for a case with $\mathrm{e}=10 \%, \mathrm{c}=30 \%$. 


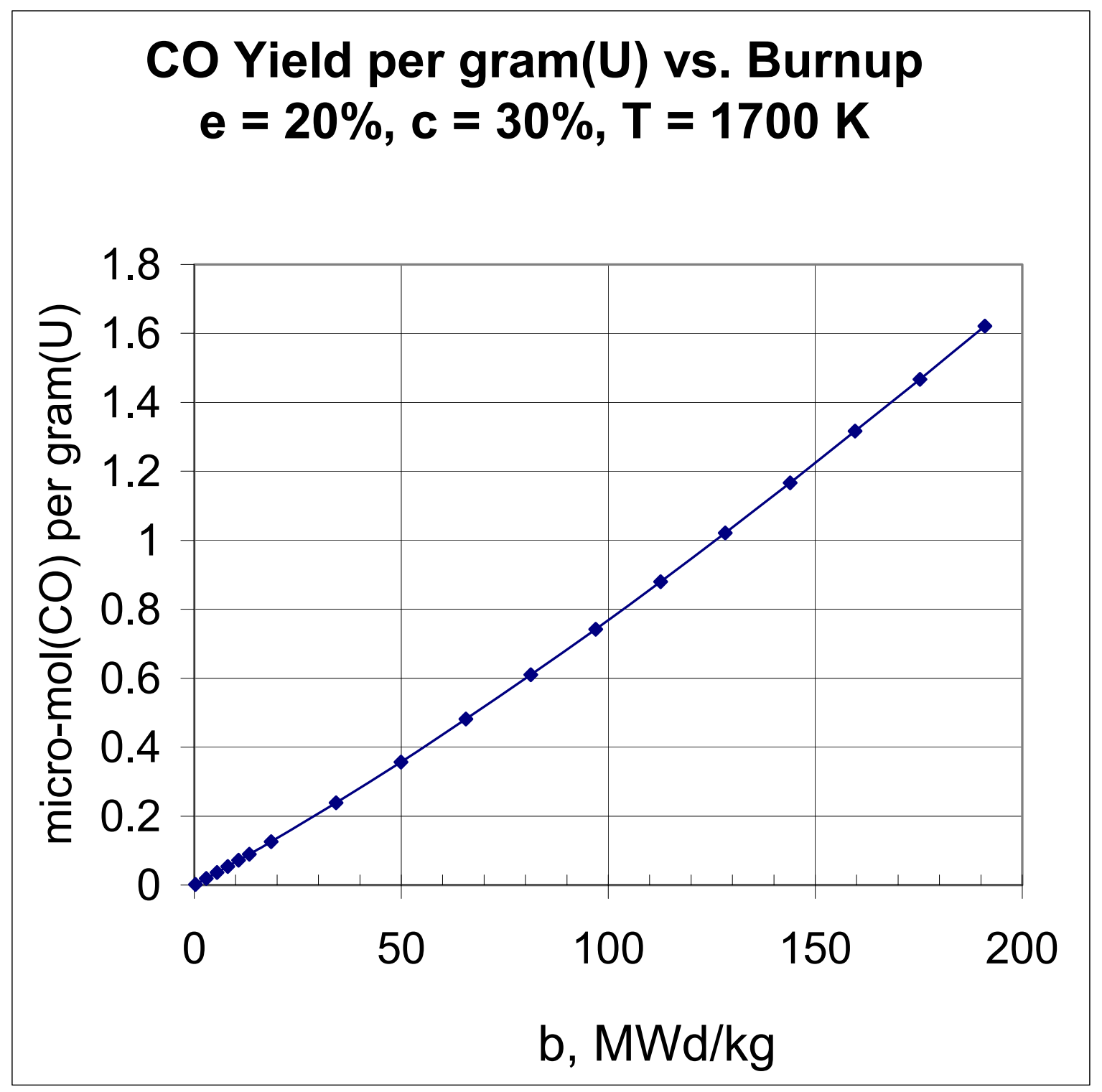

Figure 2-8 Variation of $\mathrm{CO}$ yield per gram(U) with burnup at $\mathrm{T}=1700 \mathrm{~K}, \mathrm{e}=20 \%, \mathrm{c}=30 \%$. 


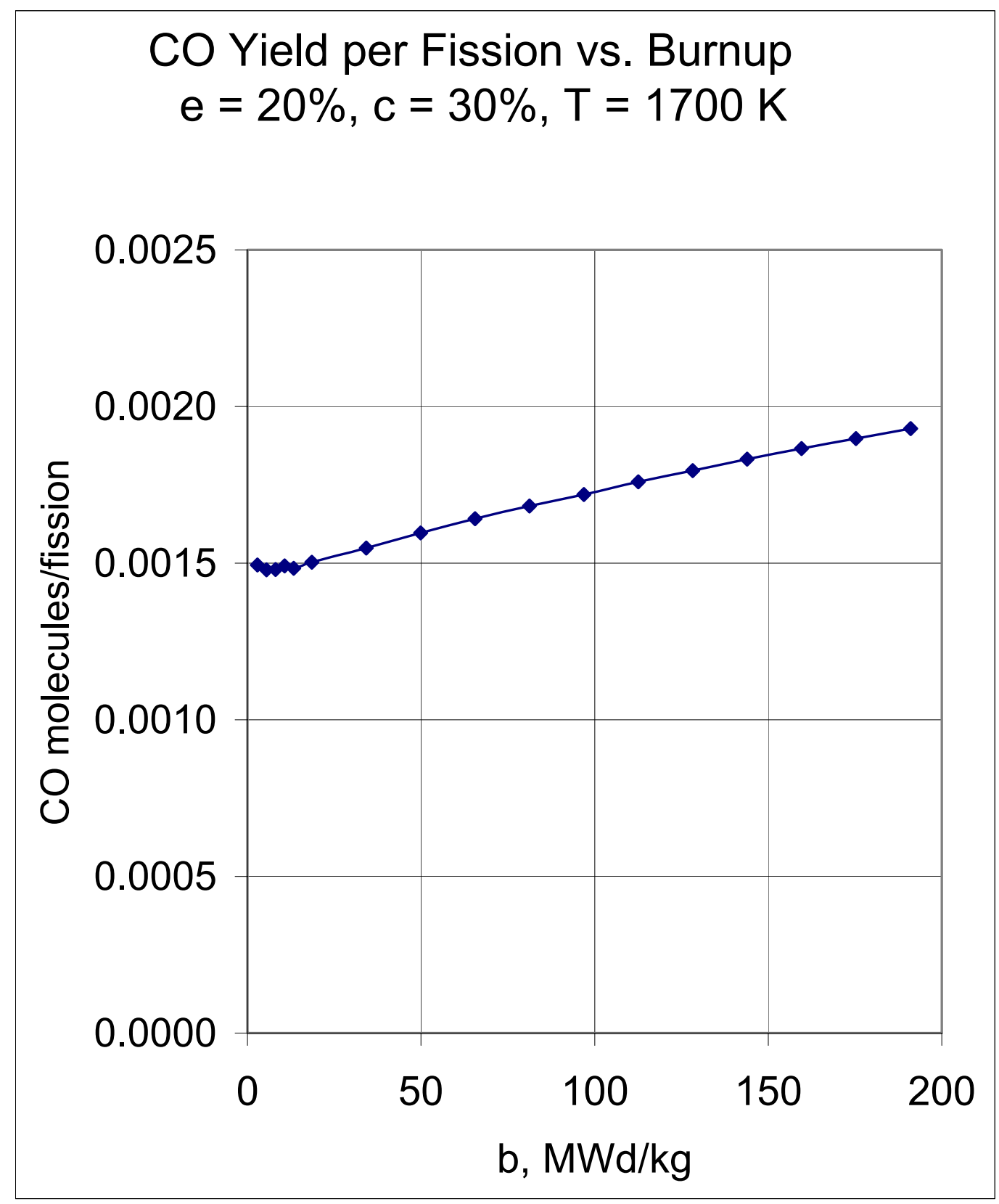

Figure 2-9. $\mathrm{CO}$ yield per fission vs. burnup at $\mathrm{T}=1700 \mathrm{~K}, \mathrm{e}=20 \%, \mathrm{c}=30 \%$. 
Figure 2-10 shows a case with fixed enrichment and burnup, but varying temperature and $\mathrm{UC}_{2}$ fraction $\mathrm{c}$. With $\mathrm{c}=0$ (top curve, pure $\mathrm{UO}_{2}$ fuel) the $\mathrm{CO}$ yield is high even at $\mathrm{T} \sim 1000 \mathrm{~K}$. Figure 2-11 shows these same data plotted vs. the $\mathrm{UC}_{2}$ fraction. There is a steep drop of the $\mathrm{CO}$ yield when $5 \%$ of $\mathrm{UC}_{2}$ is added to the fuel. Then there is a relatively flat plateau for $\mathrm{UC}_{2}$ fractions of $10 \%$ to $90 \%$. Finally, as the $\mathrm{UC}_{2}$ fraction approaches $100 \%$, the CO concentration drops to zero, because there is no source of oxygen left in the fuel-buffer region. Figure 2-12 shows the region of $0-10 \% \mathrm{UC}_{2}$ concentration in more detail. Most of the transition occurs at $\mathrm{c}<5 \%$. These results are less restrictive than the estimate of Czechowicz (1992) that a $\mathrm{UC}_{2}$ fraction of $15 \%$ would be required to suppress $\mathrm{CO}$ formation. In a strong temperature gradient the $\mathrm{CO}$ gas could lead to anomalous carbon transport in the buffer and IPyC region, called the “amoeba effect." (Wagner-Löffler 1977) Homan et al. (1977) showed that a $\mathrm{UC}_{2}$ fraction of $15 \%$ eliminated both the amoeba effect and $\mathrm{SiC}$ oxidation, but they did not study cases with $\mathrm{UC}_{2}$ fractions in the range $0<\mathrm{c}<15 \%$.

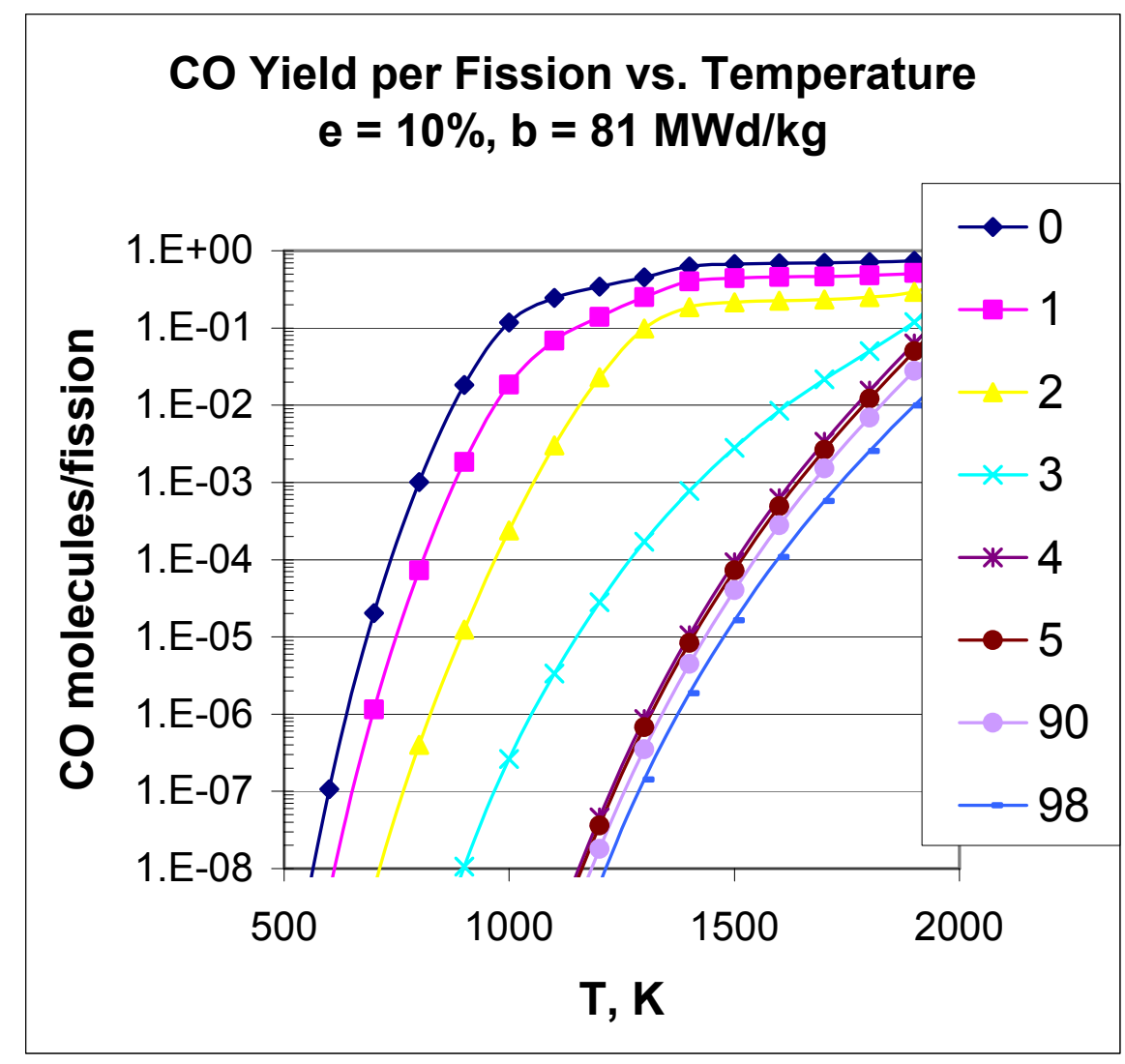

Figure 2-10. $\mathrm{CO}$ yield per fission vs. temperature at various $\mathrm{UC}_{2}$ fractions for a case with $\mathrm{e}=10 \%$, $\mathrm{b}=81 \mathrm{MWd} / \mathrm{kg}$. 


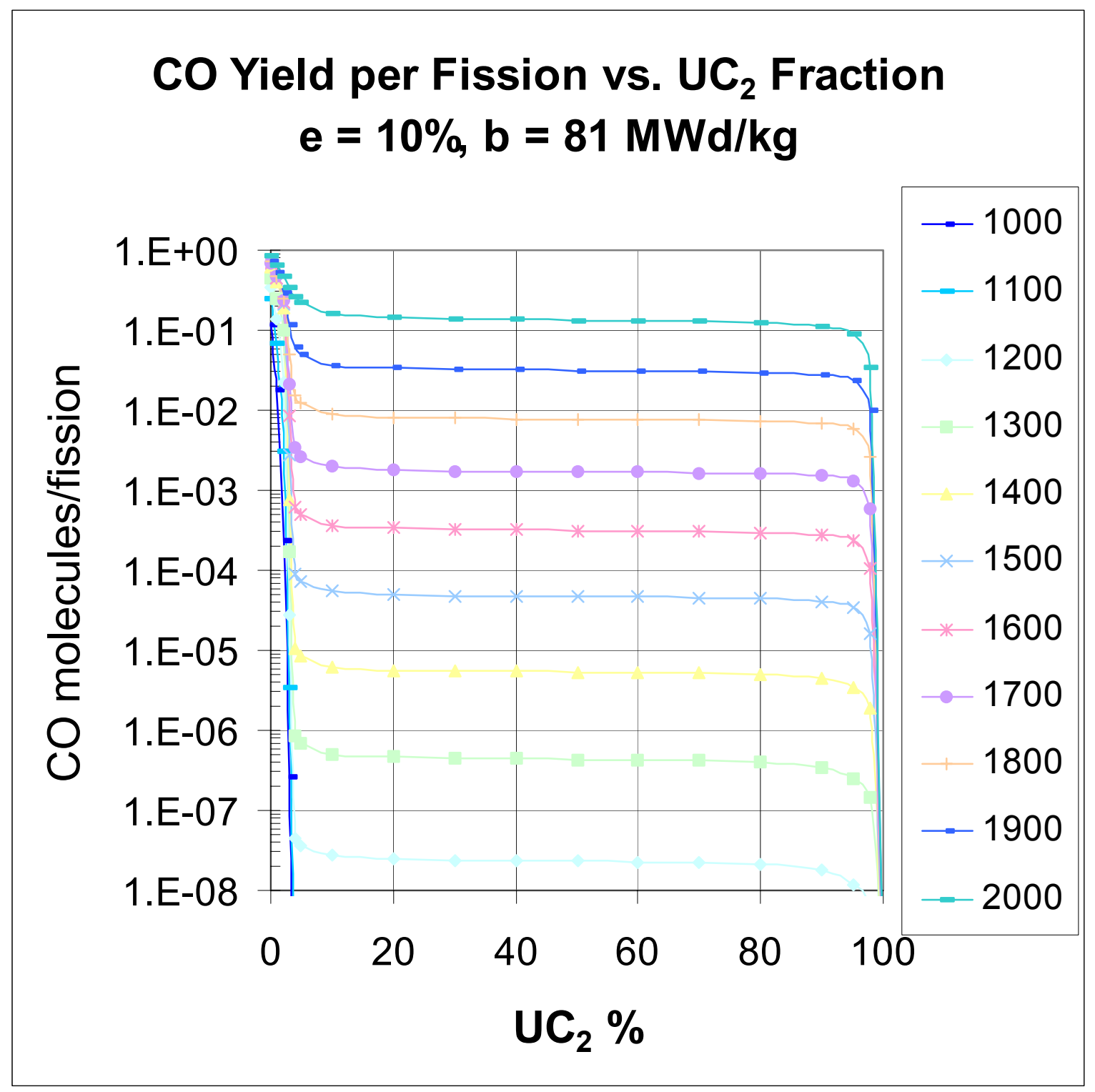

Figure 2-11. $\mathrm{CO}$ yield per fission vs. $\mathrm{UC}_{2}$ fraction at various temperatures for a case with $\mathrm{e}=10 \%$, $\mathrm{b}=81 \mathrm{MWd} / \mathrm{kg}$. 


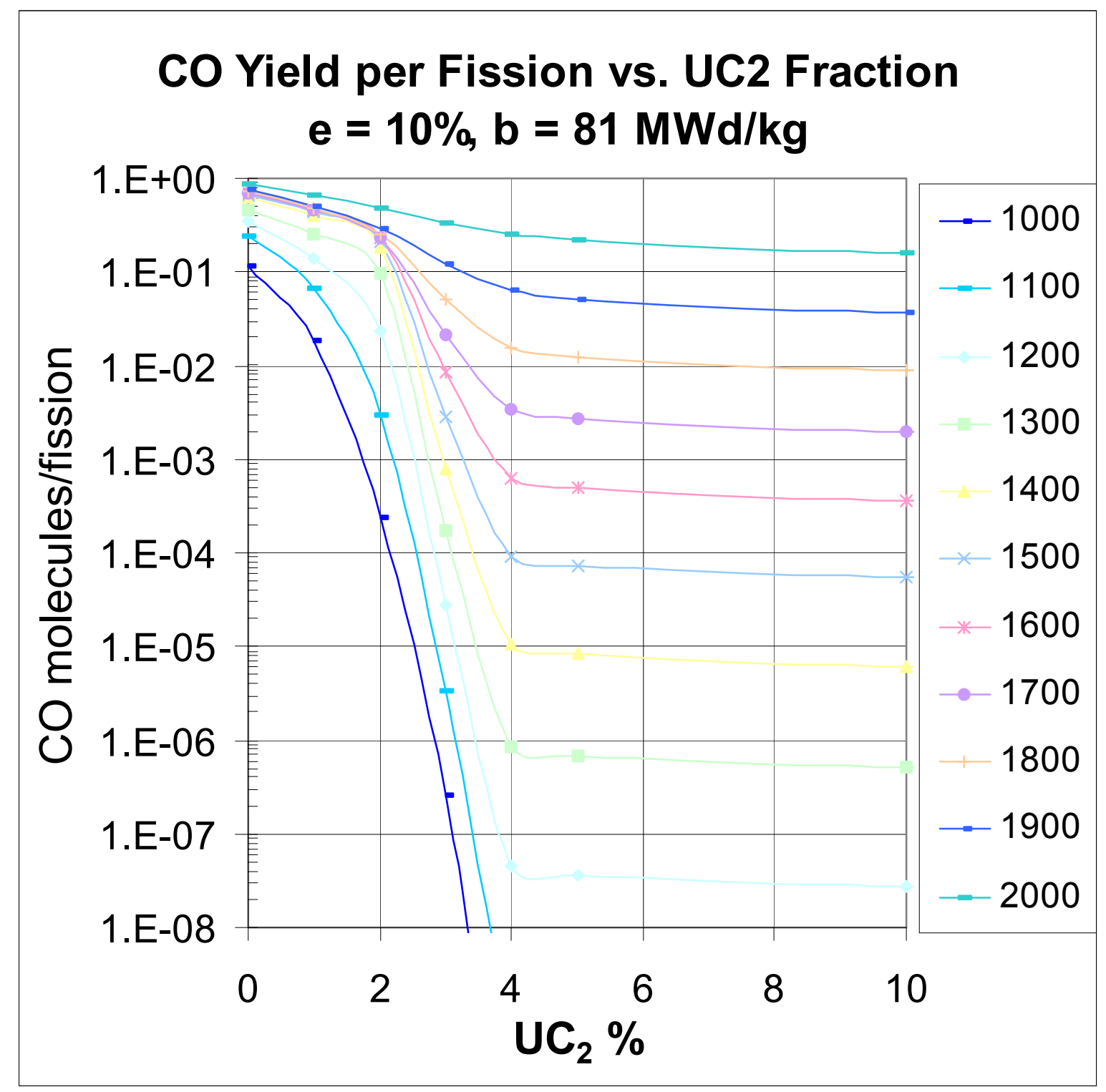

Figure 2-12. Details of the $\mathrm{c}=0-10 \%$ region, $\mathrm{CO}$ yield per fission vs. $\mathrm{UC}_{2}$ fraction at various temperatures for a case with $\mathrm{e}=10 \%, \mathrm{~b}=81 \mathrm{MWd} / \mathrm{kg}$.

The CO yield varies only slightly with fuel enrichment e. Figure 2-13 shows Y (e)/Y (10), the ratio of the yield at various enrichments to the yield at $\mathrm{e}=10 \%$, as a function of enrichment, for a wide variety of other parameters. The yield varies only a few percent with enrichment. Although this variation is slight, it must be taken into account in the algorithm that represents $\mathrm{Y}(\mathrm{b}, \mathrm{c}$, and $\mathrm{e}, \mathrm{T})$. 


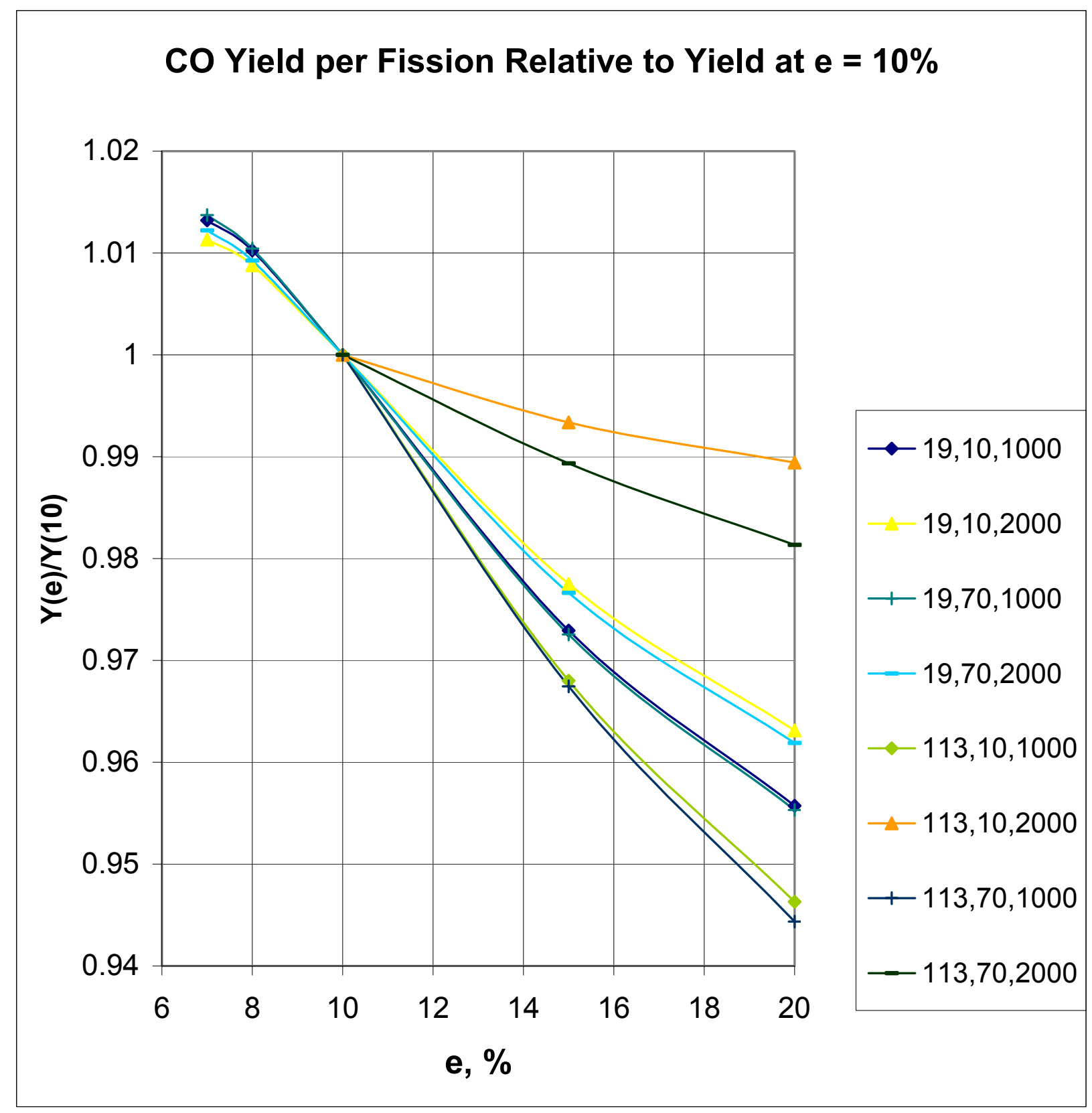

Figure 2-13. Ratio $\mathrm{CO}$ yield per fission at various enrichments to the yield at $\mathrm{e}=10 \% \mathrm{vs}$ enrichment, for a wide variety of other parameters. Legend notation: " $19,10,1000$ " means $b=19 \mathrm{MWd} / \mathrm{kg}, \mathrm{c}=10 \%$, $\mathrm{T}=1000 \mathrm{~K}$. 


\subsection{Case With Only $\mathrm{UO}_{2}$}

The $\mathrm{CO}$ yield has been calculated for a case with $\mathrm{c}=0$ (no $\mathrm{UC}_{2}$, only $\mathrm{UO}_{2}$ fuel). The variation of $\mathrm{CO}$ yield per gram $(\mathrm{U})$ with temperature is shown in Figure 2-14. These yields are also shown as molecules CO per fission in Figure 2-15. The slope of the curves is small from 1500 to $1800 \mathrm{~K}$, and then it increases again. There are many slight wiggles in the curves, which correspond to growth of some compounds involving oxygen and destruction of others. For example, Table 2-8 shows how the concentrations of some compounds vary by orders of magnitude as the temperature changes a few hundred degrees (highlighted in boldface). From a comparison of Tables 2-7 and 2-8 we can see that some compounds are generated in $\mathrm{UO}_{2}$ fuel that are less significant in $\mathrm{UCO}$ fuel, such as $\mathrm{Cs}_{2} \mathrm{O}^{*} \mathrm{MoO}_{3}$, $\mathrm{BaMoO}_{4}, \mathrm{BaO}^{*} \mathrm{UO}_{3}$, and $\mathrm{BaCO}_{3}$.

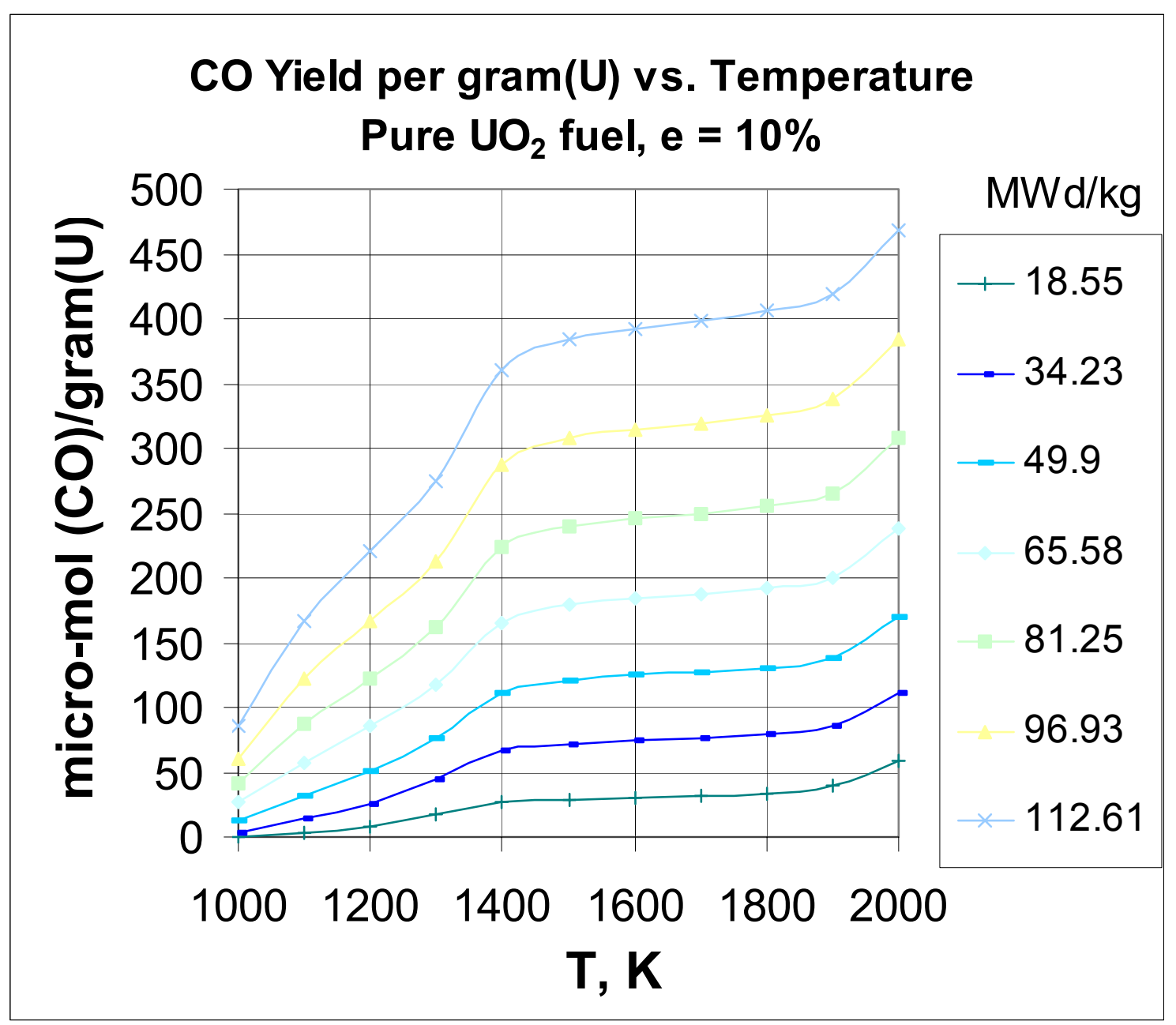

Figure 2-14. $\mathrm{CO}$ yield per gram (U) vs. temperature for case with pure $\mathrm{UO}_{2}$ fuel $(\mathrm{c}=0), \mathrm{e}=10 \%$ at various values of burnup. The yield per fuel pebble is nine times as large. 


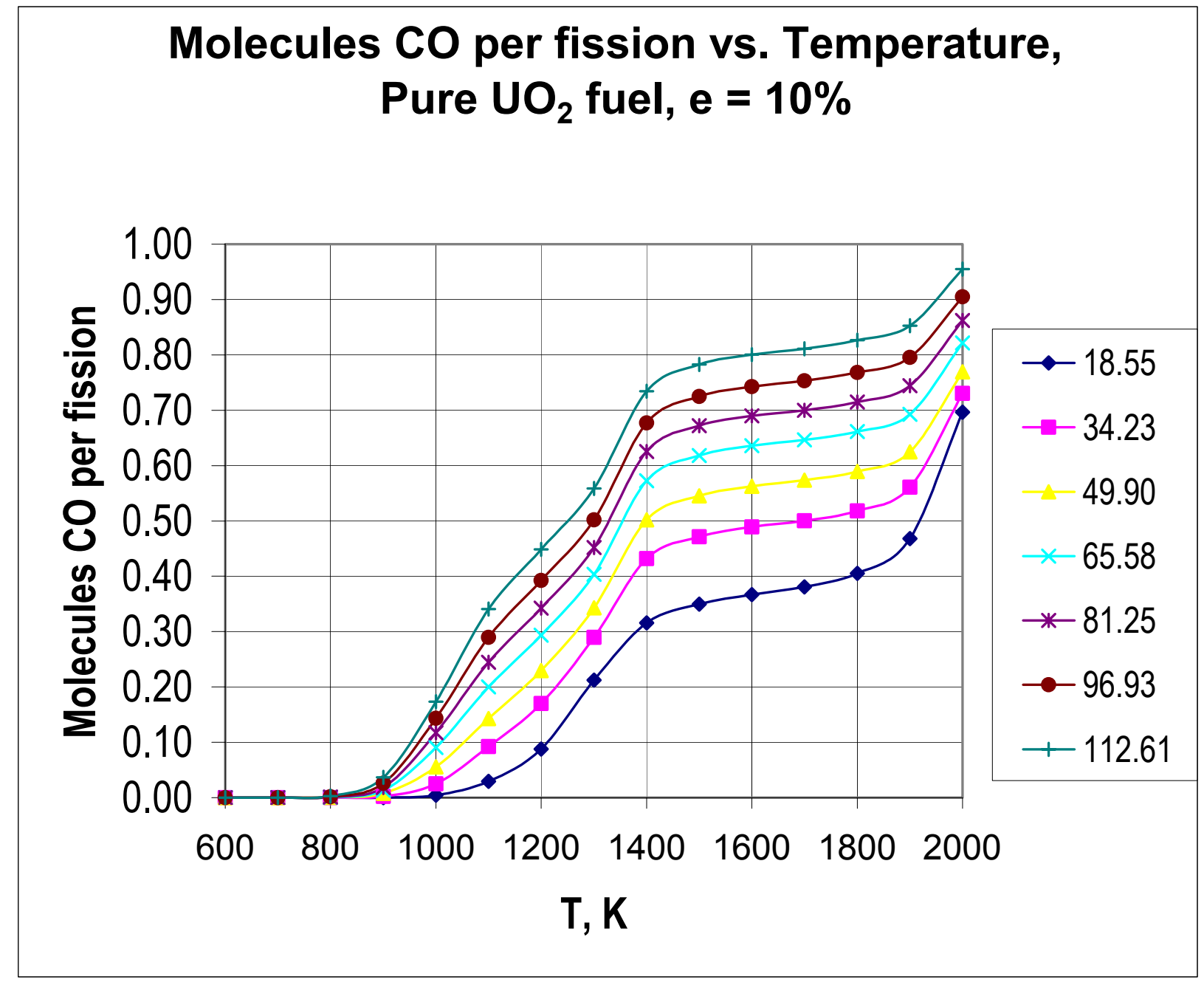

Figure 2-15. $\mathrm{CO}_{2}$ yield per fission vs. temperature for pure $\mathrm{UO}_{2}$ fuel, $\mathrm{e}=10 \%$, at various values of burnup. 
Table 2-8. Concentrations (mol/pebble) in pure $\mathrm{UO}_{2}$ fuel with $=10 \%, \mathrm{~b}=113 \mathrm{MWd} / \mathrm{kg}$.

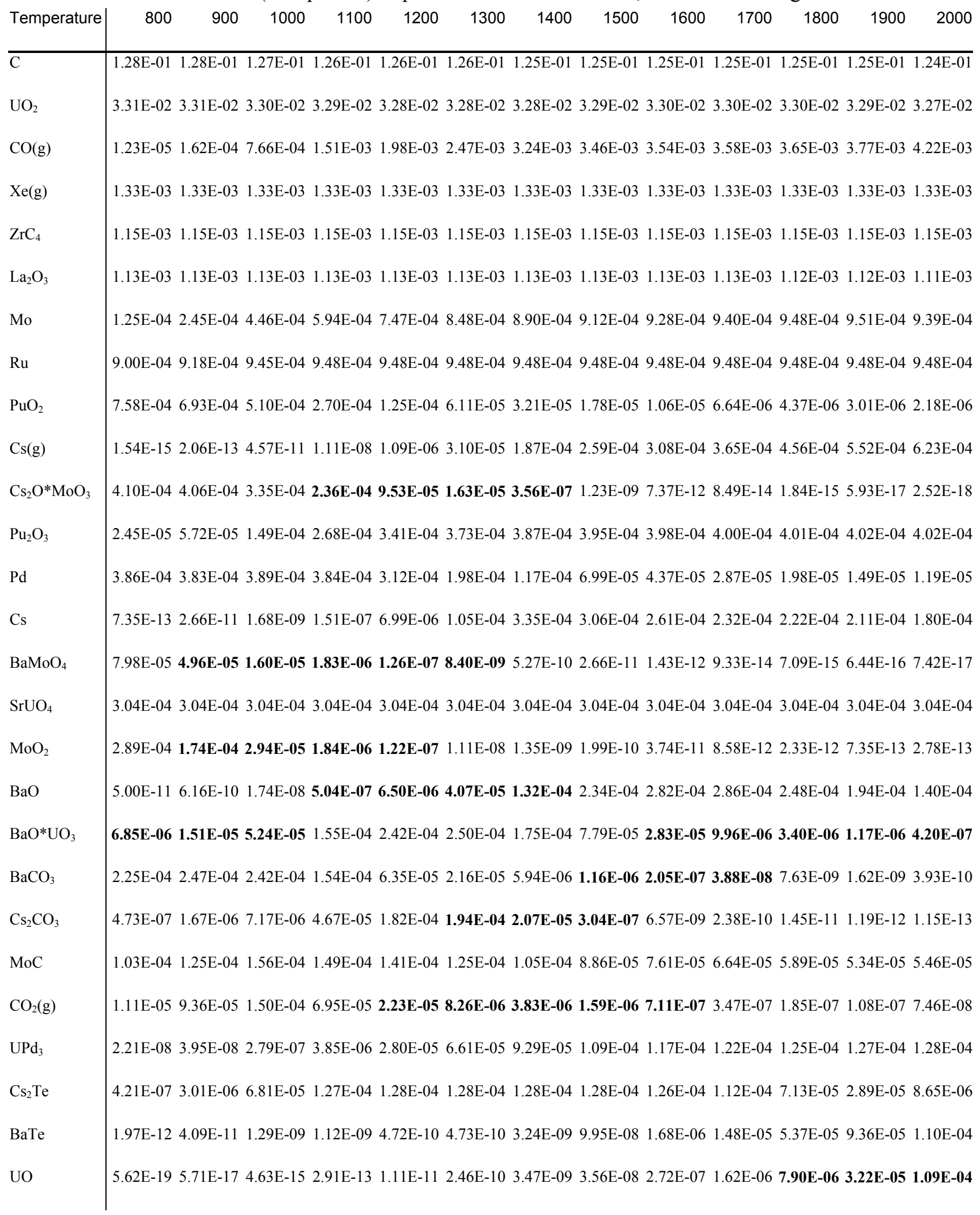




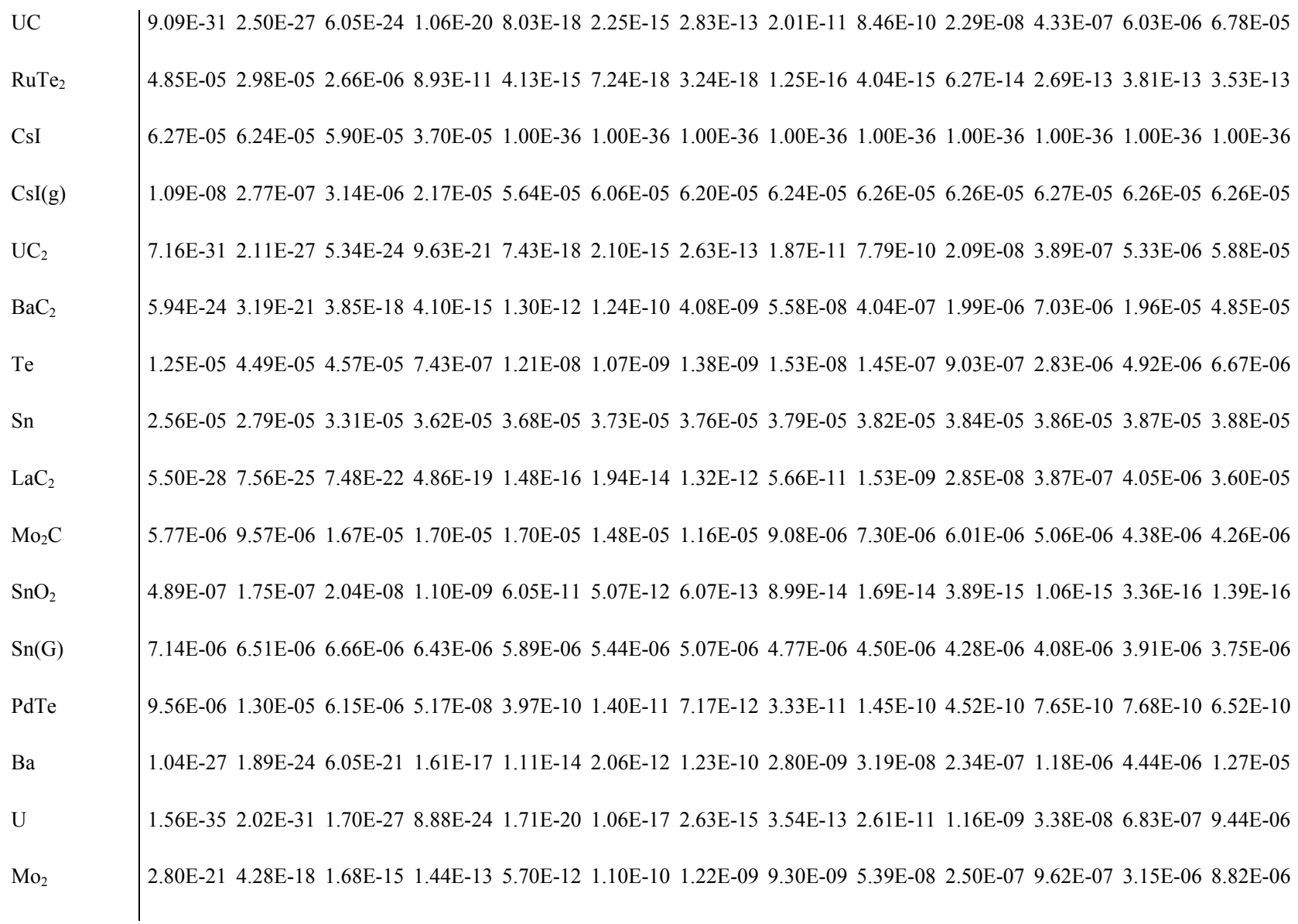

Figure 2-16 shows the $\mathrm{CO}$ yield per gram (U) vs. burnup. There is a slight upward curvature. The yield per fission, Figure 2-17, does not go to zero at very small values of burnup. These HSC predictions can be compared with results from previous works. 


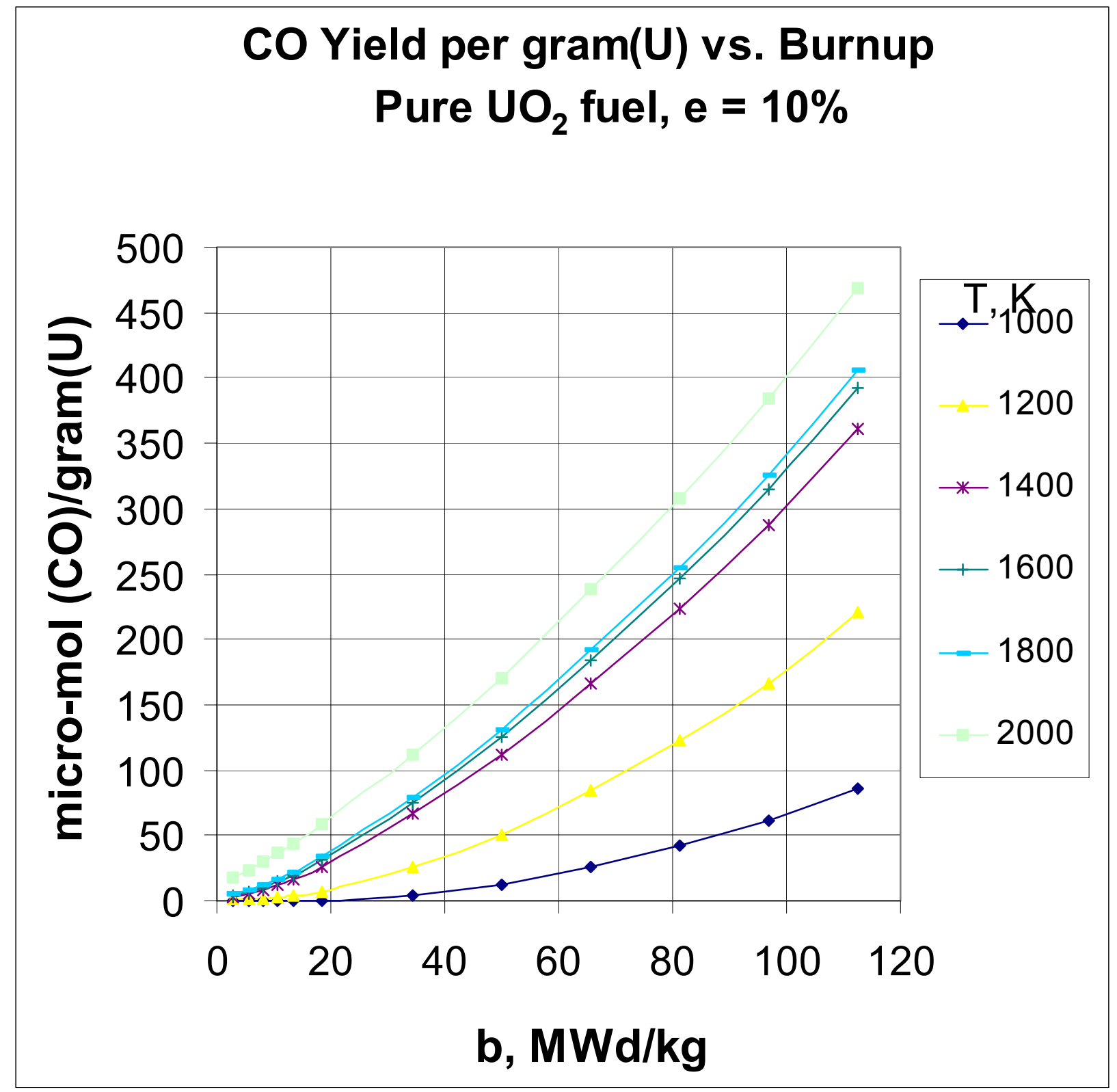

Figure 2-16. $\mathrm{CO}$ yield per gram(U) vs. burnup, for case with pure $\mathrm{UO}_{2}$ fuel $(\mathrm{c}=0 \%), \mathrm{e}=10 \%$ at various temperatures. The yield per fuel pebble is nine times larger. 


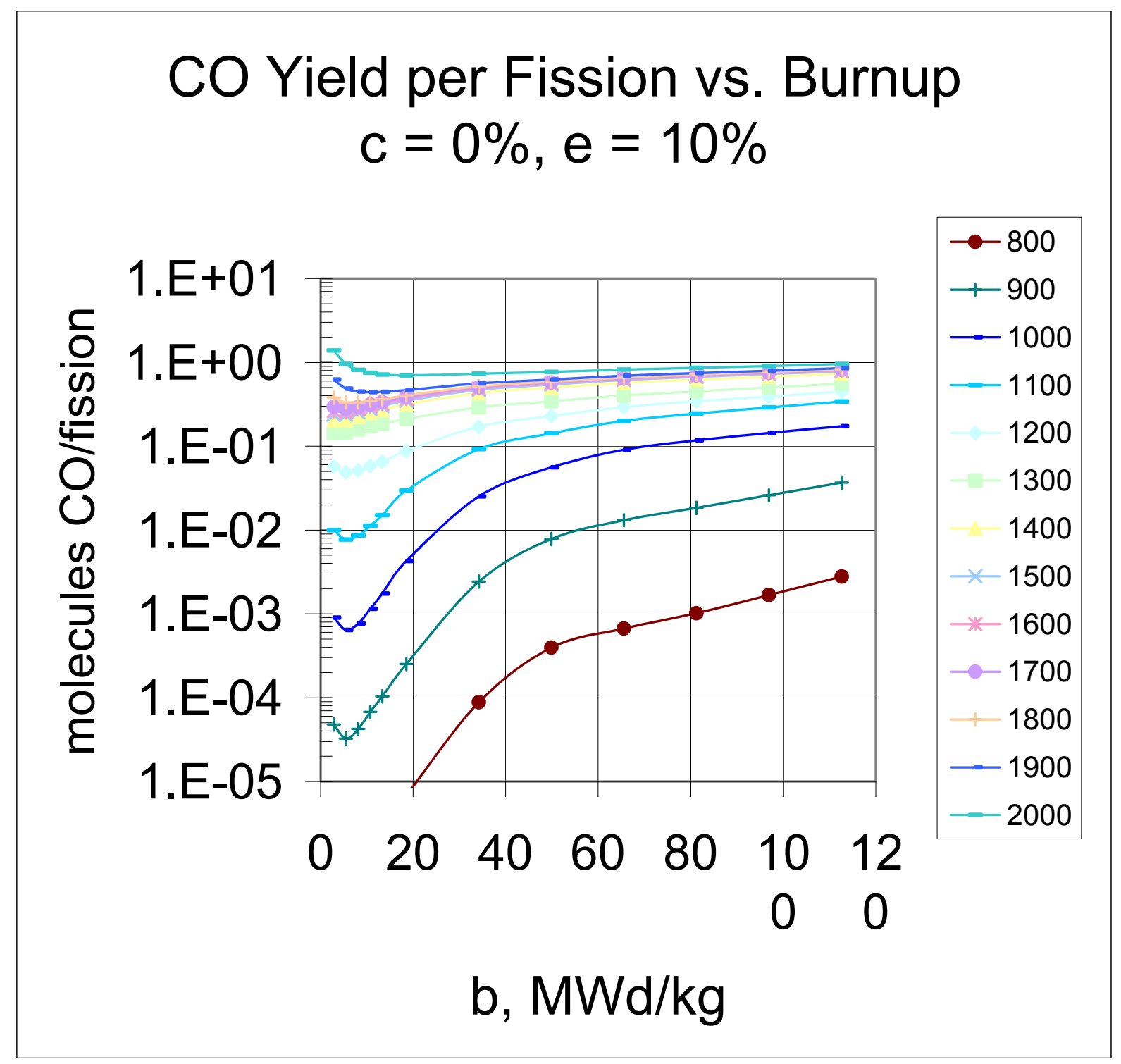

Figure 2-17. $\mathrm{CO}$ yield per fission vs. burnup in pure $\mathrm{UO}_{2}$ fuel with $\mathrm{e}=10 \%$, at various temperatures.

In pure $\mathrm{UO}_{2}$ fuel there is also a substantial yield of $\mathrm{CO}_{2}$, which peaks at $\mathrm{T} \sim 1000 \mathrm{~K}$ at high burnup, as shown in Figure 2-18. (In UCO fuel, on the other hand, the yield of $\mathrm{CO}_{2}$ is negligible compared with the yield of CO, as shown in Figure 2-19.) 


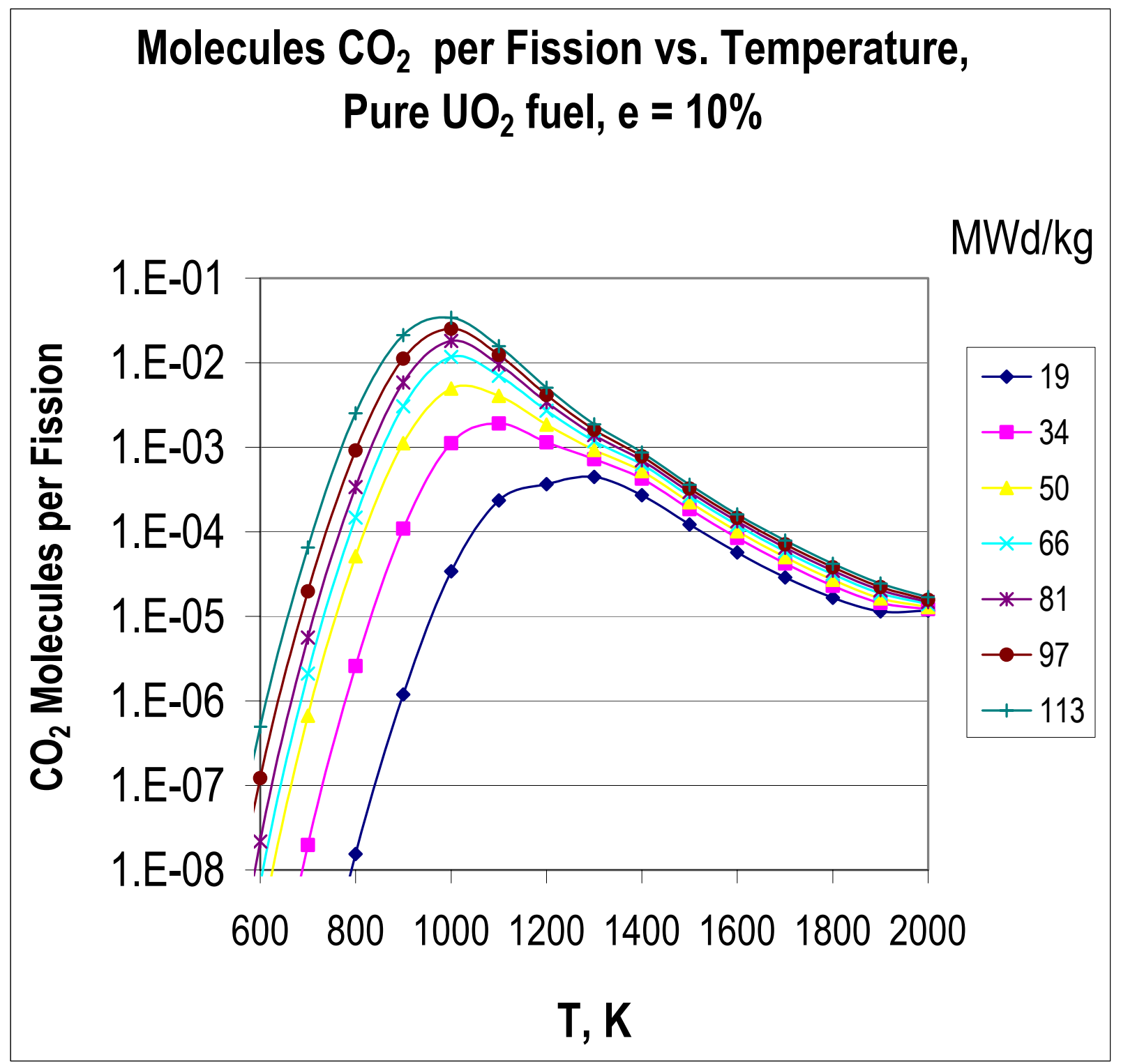

Figure 2-18. $\mathrm{CO}_{2}$ yield vs. Temperature for pure $\mathrm{UO}_{2}$ fuel with $\mathrm{e}=10 \%$, at various values of burnup. 


\section{$\mathrm{CO}_{2} / \mathrm{CO}$ Ratio vs. Temperature $e=10 \%, c=30 \%, b=113 \mathrm{MWd} / \mathrm{kg}$}

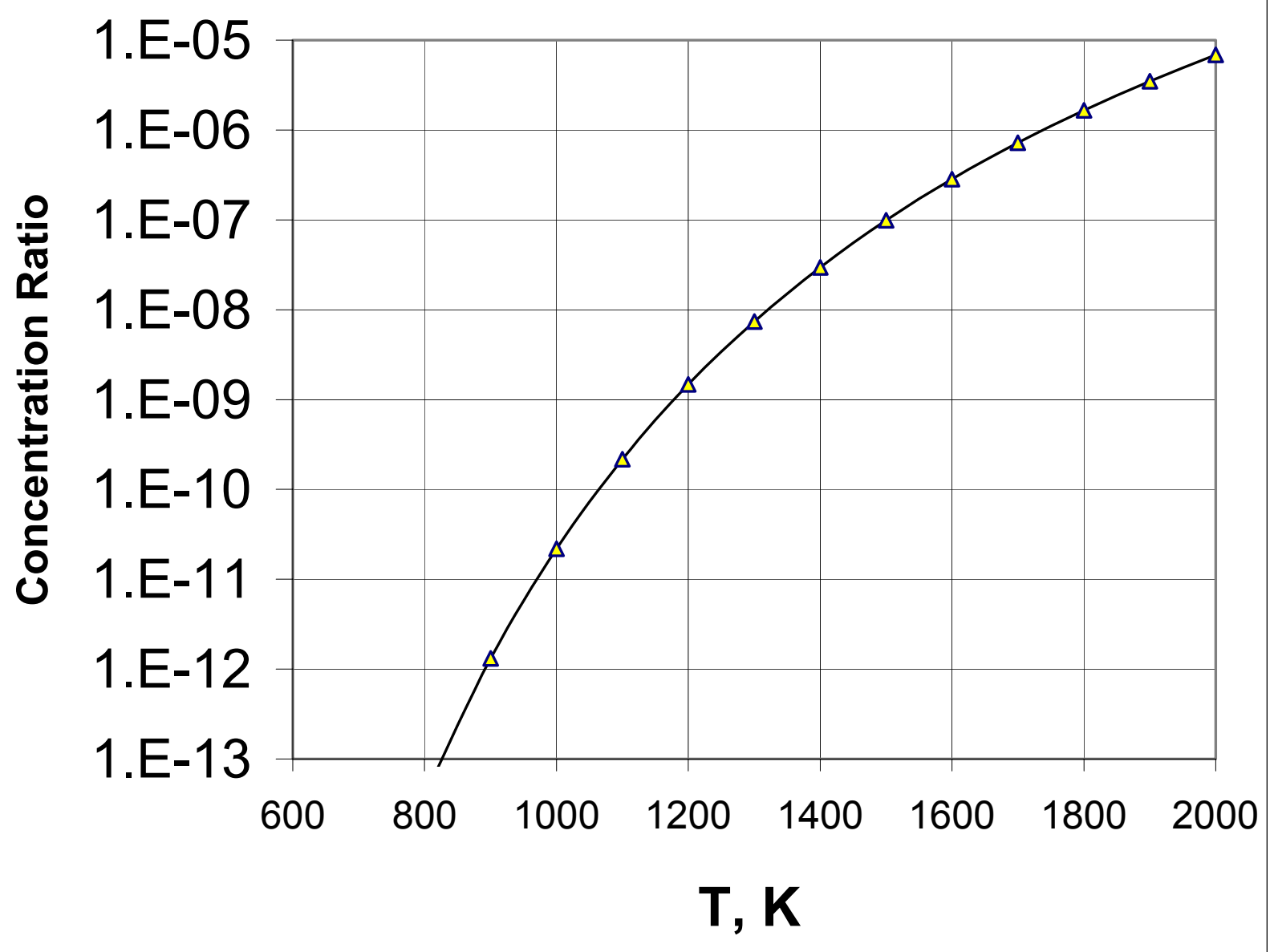

Figure 2-19. Concentration ratio of $\mathrm{CO}_{2} / \mathrm{CO}$ vs. temperature, for a case with $\mathrm{e}=10 \%, \mathrm{c}=30 \%$, $\mathrm{b}=113 \mathrm{MWd} / \mathrm{kg}$.

The HSC code estimates of $\mathrm{CO}$ yield in pure $\mathrm{UO}_{2}$ fuel may be compared with algorithms derived in previous works. Horsley et al. (1976) give the following empirical functions for estimation of the oxygen atoms released per fission (= the number $\mathrm{CO}$ molecules generated per fission) vs. temperature:

$$
Y=f(U) Y_{U}+f(P u) Y_{P u}
$$




$$
\begin{aligned}
& Y_{U}=10^{(2.244-6300 / \mathrm{T})} \\
& Y_{\mathrm{Pu}}=10^{(0.215-1438 / \mathrm{T})}
\end{aligned}
$$

where $f(P u)=($ fraction of fissions in $\mathrm{Pu})$ and $f(U)=($ fraction of fissions in $U)=1-f(P u)$, and $T=$ fuel particle temperature $(\mathrm{K})$. This algorithm is valid only near the irradiation temperature, which was 1473$1573 \mathrm{~K}$. (Note: The fuel temperature varies with position, so using one "average" temperature value could lead to error.)

Proksch et al. (1982) compared measurements of $\mathrm{CO}$ release after crushing $\mathrm{UO}_{2}$ fuel particles and derived the following empirical algorithm for the $\mathrm{CO}$ molecules released per fission:

$$
\mathrm{Y}=\tau^{2} 10^{-(0.21+8500 / \mathrm{T})}
$$

where $\tau=$ irradiation time (days) and $\mathrm{T}=$ Temperature (K). This algorithm is valid only in the range $1223<\mathrm{T}<1798 \mathrm{~K}, \mathrm{Y}<0.42$, and $66<\tau<550$ days. (Note that the relation between time and burnup will differ from one reactor to another, so time is not a good variable to use for such comparisons. It would be better to use atomic burnup. Table 2-4 shows the relation between burnup and time for the example fuel design studied here.)

Proksch et al. (1982) also calculated the yield of oxygen atoms per fission, assuming formation of $\mathrm{BaO}$, $\mathrm{SrO}$, and $\mathrm{ZrO}_{2}$, considering whether the lanthanides are trivalent or tetravalent. For fissions in a mixture ${ }^{235} \mathrm{U}$ and ${ }^{239} \mathrm{Pu}$ they found:

Trivalent lanthanides: $\quad \mathrm{Y}=0.40 \mathrm{f}(\mathrm{U})+0.85 \mathrm{f}(\mathrm{Pu})$

Tetravalent lanthanides: $\quad \mathrm{Y}=0.13 \mathrm{f}(\mathrm{U})+0.62 \mathrm{f}(\mathrm{Pu})$

(For fissions in ${ }^{241} \mathrm{Pu}$ the coefficients are almost the same, so it is not necessary to take into account the fraction of fissions that occur in that isotope.) These theoretical yields are higher than the empirical release rate of Equation (10).

Kovacs (1985) cites the following empirical correlation for oxygen release from low-enriched $\mathrm{UO}_{2}$ fuel:

$$
\mathrm{Y}=1.64 \exp (-3311 / \mathrm{T}) \text {. }
$$


This algorithm has no dependence on time or burnup. It is probably valid only at $\mathrm{T}>1200 \mathrm{~K}$.

The predictions of the HSC code are compared with the Proksch algorithm (10) and the Kovacs algorithm (13) in Figures 2-20 - 2-21. The Kovacs algorithm is roughly consistent with the other curves at $\mathrm{T}>$ $1200 \mathrm{~K}$. The HSC code prediction is close to the Proksch algorithm at low and high temperatures, but HSC exceeds the Proksch algorithm by up to a factor of 10 at intermediate temperatures. This may be due to two factors:

(1) The HSC computations predict the yield, while the experimental data represent CO molecules released from the fuel during heating. The release will always be less than the yield.

(2) The present computations assume that all the oxygen released in the kernel has free access to all the carbon in the buffer. Kinetics limitations may be operable, in some cases, especially at low temperatures. 


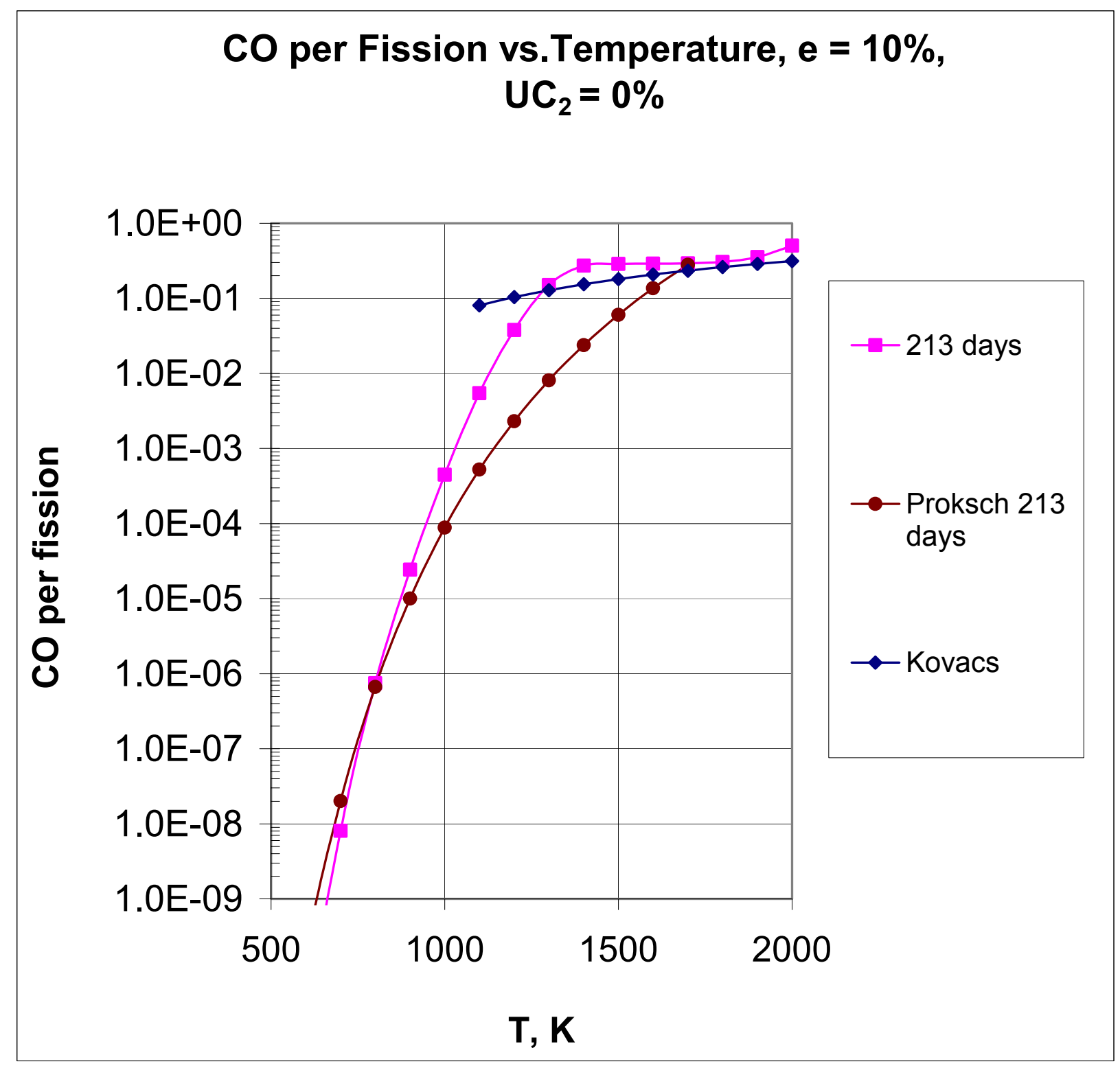

Figure 2-20. HSC predictions of $\mathrm{CO}$ yield per fission vs. temperature for a case with pure $\mathrm{UO}_{2}$ fuel $(\mathrm{c}=0)$, compared with empirical formulas (Proksch 1982 and Kovacs 1985) at $\mathrm{t}=213$ days (roughly $19 \mathrm{MWd} / \mathrm{kg}$ ). 


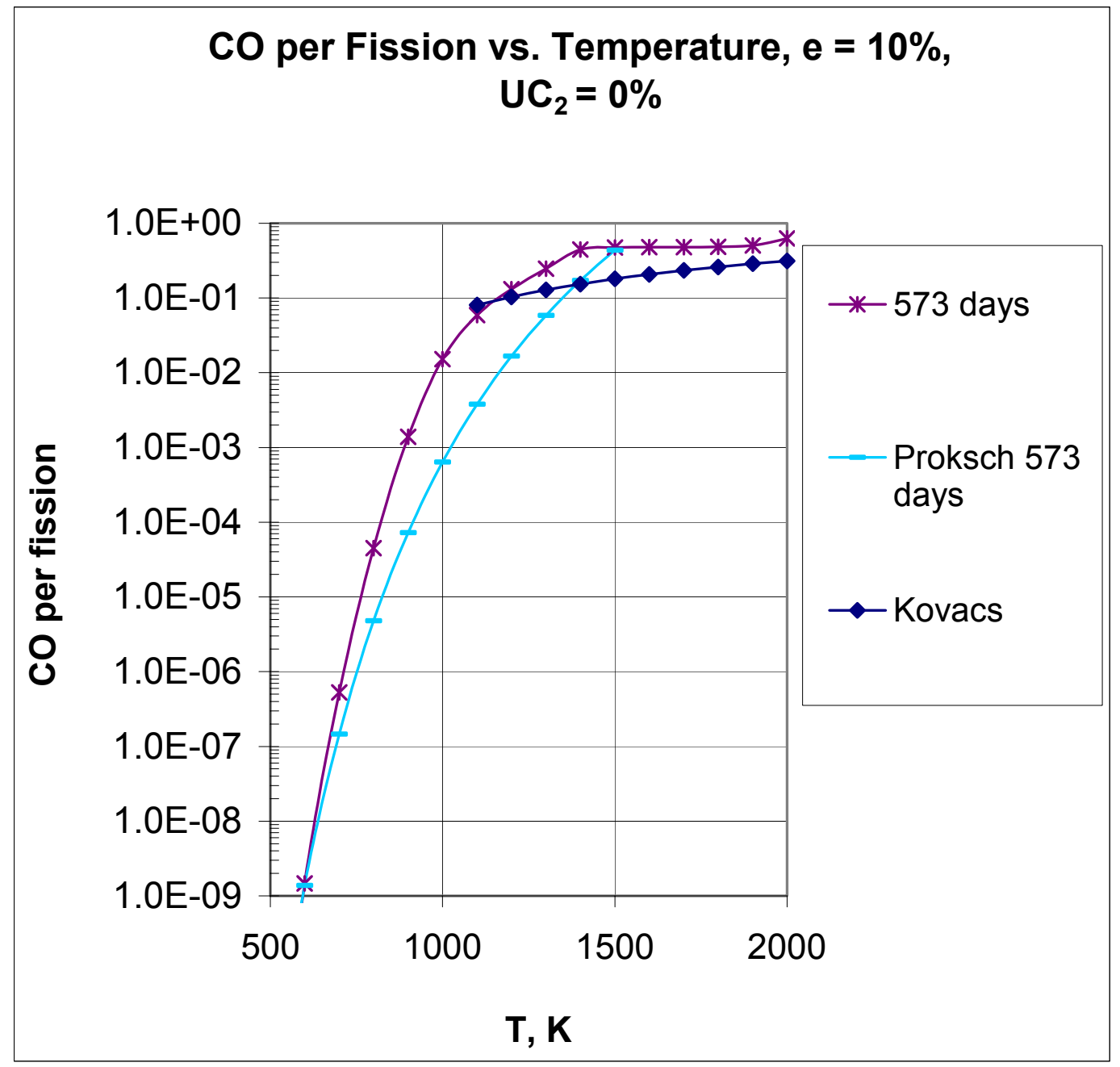

Figure 2-21. HSC predictions of $\mathrm{CO}$ yield per fission vs. temperature for a case with pure $\mathrm{UO}_{2}$ fuel $(c=0)$, compared with empirical formulas (Proksch 1982 and Kovacs 1985) at $t=573$ days (approximately $50 \mathrm{MWd} / \mathrm{kg}$ ).

Figure 2-22 shows the fraction $\mathrm{f}(\mathrm{Pu})$ of fissions occurring in plutonium isotopes vs. burnup calculated by MOCUP. Figure 2-23 compares the HSC predictions at $1200 \mathrm{~K}$ with the Proksch empirical algorithm (10). It is apparent that the Proksch values are about an order of magnitude lower than the HSC predictions at this temperature, as seen previously in Figures 2-20 and 2-21. Figure 2-24 compares HSC code predictions of CO yield per fission vs. time at $1500 \mathrm{~K}$ with the Proksch empirical algorithm (10), with the Proksch theoretical trivalent and tetravalent estimates of Equations (11) and (12), and with the Horsley empirical algorithm (9). The HSC predictions lie between the two valence curves, approaching the trivalent curve at high temperature. The empirical algorithms of Proksch and of Horsley represent release, rather than yield. 


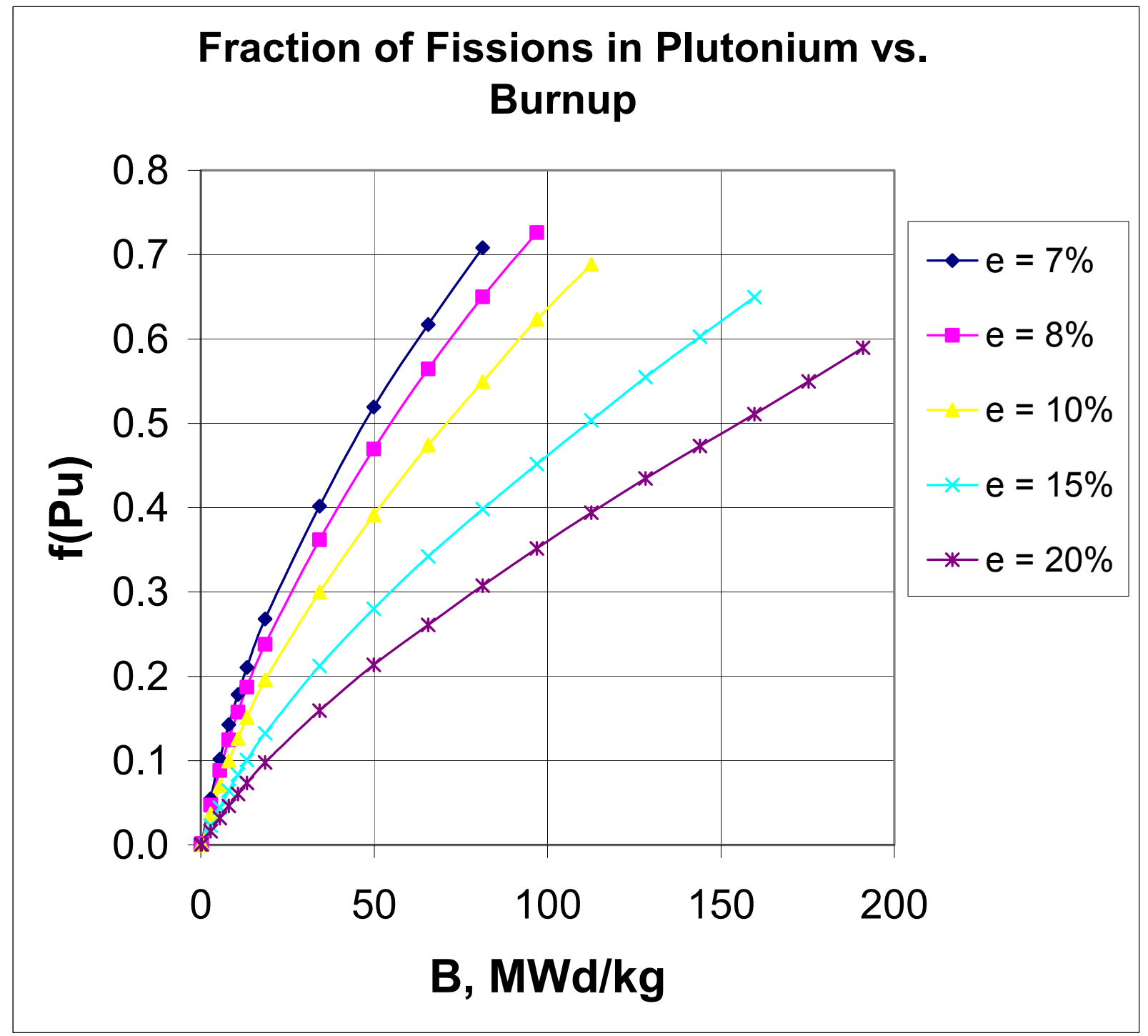

Figure 2-22. Fraction of fissions occurring in plutonium vs. burnup, for various enrichments. 


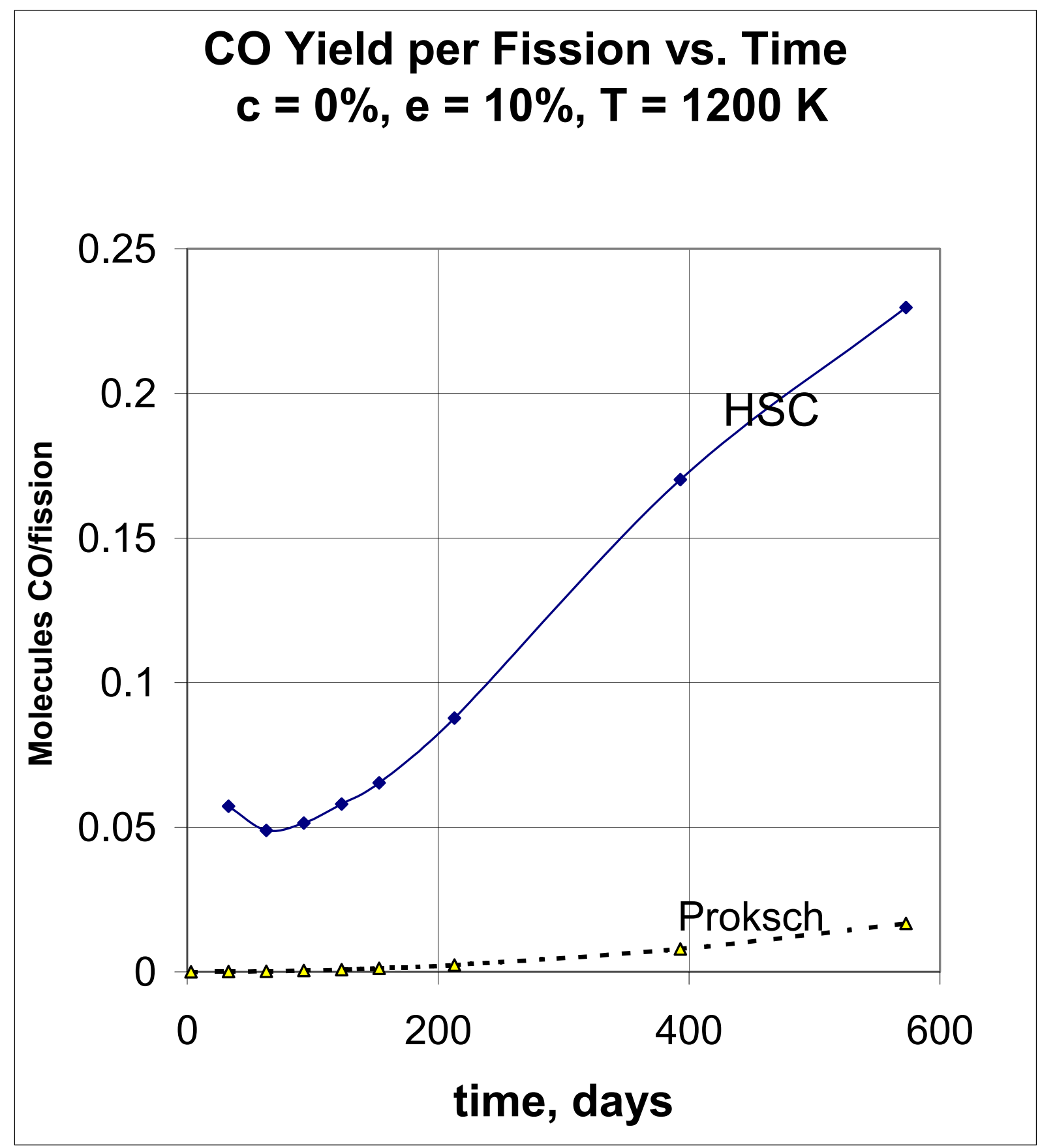

Figure 2-23. CO yield per fission vs. time at $1200 \mathrm{~K}$, HSC predictions compared with the Proksch correlation. 


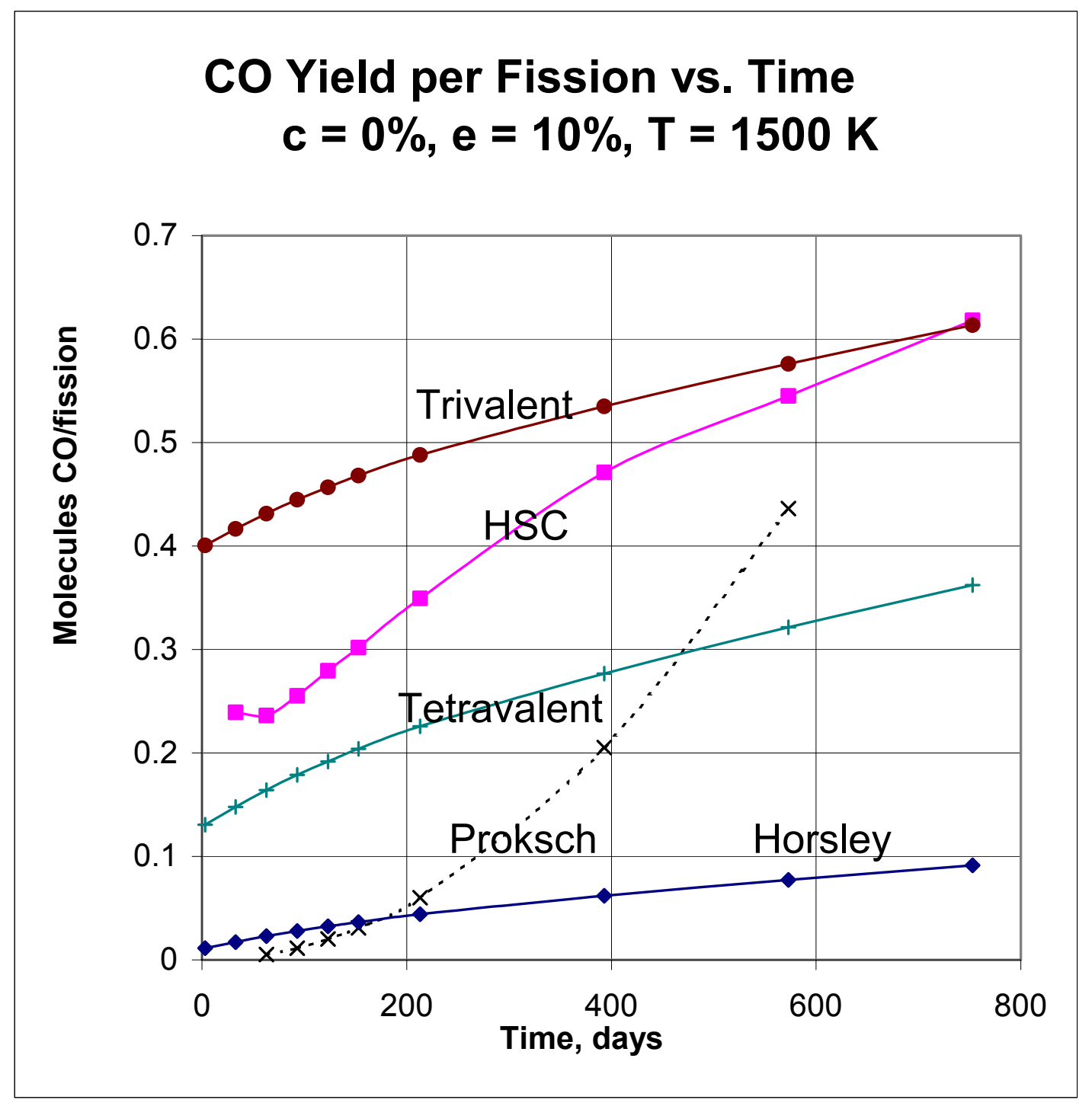

Figure 2-24. Comparison of HSC estimate of CO yield per fission at $1500 \mathrm{~K}$ with the Proksch (1982) correlation, with the Proksch (1982) theoretical estimates (dependent on valence of lanthanides), and with the empirical algorithm of Horsley (1976).

Figure 2-25 compares the HSC code predictions vs. time at $\mathbf{1 8 0 0} \mathbf{K}$ with the Proksch empirical algorithm (10) and with the Proksch theoretical trivalent and tetravalent estimates of Equations (11) and (12). The HSC curve is close to the trivalent theoretical curve. The other curves are significantly lower. It would be prudent to use the more conservative estimates of $\mathrm{HSC}$, since the empirical algorithms represent $\mathrm{CO}$ released, which can be lower than the actual CO yield. Most of the past data has been at atomic burnup values below $10 \%$. There is a need for more empirical data at higher burnup (longer times). 


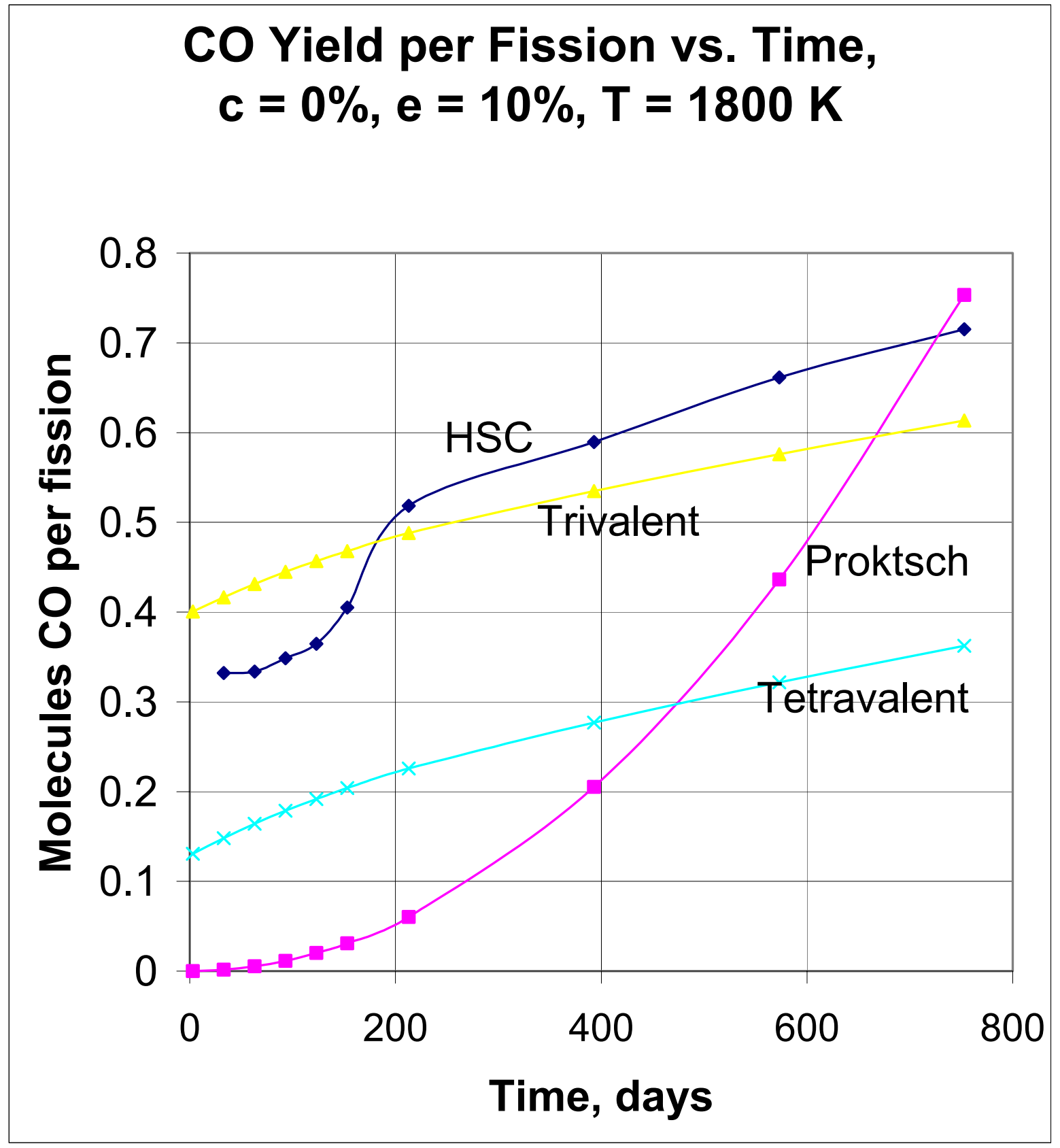

Figure 2-25. CO yield per fission vs. time at $1800 \mathrm{~K}$, HSC predications compared with Proktsch algorithms. 


\subsection{Gas Pressures}

In addition to the main calculations with buffer density $=0.85 \mathrm{~g} / \mathrm{cm}^{3}(61 \%$ porosity $)$, some cases with buffer density $=1.1 \mathrm{~g} / \mathrm{cm}^{3}$ (50\% porosity) were also studied for cases with maximum burnup. The results, shown in Table 2-9, show that the yields of $\mathrm{CO}$ and $\mathrm{CO}_{2}$ differ negligibly with this change of buffer density. The $\mathrm{CO}_{2}$ yield is significant in the pure $\mathrm{UO}_{2}$ fuel ( $\mathrm{c}=0$ cases), but insignificant in the UCO fuel ( $c=30 \%$ cases $)$. 
Table 2-9. Yield (mol/pebble) of $\mathrm{CO}$ and $\mathrm{CO}_{2}$ vs. temperature, comparing two values of buffer density, $\rho$ $=085$ and $1.1 \mathrm{~g} / \mathrm{cm}^{3}$. Here "e20c00b191" means e $=20 \%, \mathrm{c}=0, \mathrm{~b}=191 \mathrm{MWd} / \mathrm{kg}$.

\begin{tabular}{|c|c|c|c|c|c|c|c|c|c|c|c|c|c|c|}
\hline & $\boldsymbol{\rho}$ & & & $\mathbf{T}, \mathbf{K}$ & & & & & & & & & & \\
\hline $\mathrm{CO}$ & $g / \mathrm{cm}^{3}$ & 800 & 900 & 1000 & 1100 & 1200 & 1300 & 1400 & 1500 & 1600 & 1700 & 1800 & 1900 & 2000 \\
\hline e20c00b191 & 0.85 & $2.79 \mathrm{E}-05$ & 3.19E-04 & $1.38 \mathrm{E}-03$ & $2.65 \mathrm{E}-03$ & 3.47E-03 & $4.30 \mathrm{E}-03$ & $5.74 \mathrm{E}-03$ & $6.12 \mathrm{E}-03$ & $6.25 \mathrm{E}-03$ & $6.33 \mathrm{E}-0$ & 6.45E-03 & $6.65 \mathrm{E}-03$ & $7.40 \mathrm{E}-03$ \\
\hline e20c00b191 & 1.1 & $2.83 \mathrm{E}-05$ & $3.23 \mathrm{E}-04$ & $1.39 \mathrm{E}-03$ & $2.65 \mathrm{E}-03$ & $3.47 \mathrm{E}-03$ & $4.32 \mathrm{E}-03$ & $5.75 \mathrm{E}-03$ & $6.12 \mathrm{E}-03$ & $6.25 \mathrm{E}-03$ & $6.33 \mathrm{E}-0$ & $6.45 \mathrm{E}-03$ & $6.65 \mathrm{E}-03$ & $7.40 \mathrm{E}-03$ \\
\hline \multicolumn{15}{|l|}{$\mathrm{CO}_{2}$} \\
\hline $\mathrm{e} 20 \mathrm{c} 00 \mathrm{~b} 191$ & 0.85 & $3.45 \mathrm{E}-05$ & 2.13E-04 & $2.86 \mathrm{E}-04$ & $1.27 \mathrm{E}-04$ & $4.05 \mathrm{E}-05$ & $1.48 \mathrm{E}-05$ & $6.89 \mathrm{E}-06$ & $2.86 \mathrm{E}-06$ & $1.27 \mathrm{E}-06$ & $6.22 \mathrm{E}-0$ & $3.31 \mathrm{E}-07$ & $1.92 \mathrm{E}-07$ & $1.33 \mathrm{E}-07$ \\
\hline e20c00b191 & 1.1 & $3.56 \mathrm{E}-05$ & $2.17 \mathrm{E}-04$ & $2.90 \mathrm{E}-04$ & $1.27 \mathrm{E}-04$ & $4.04 \mathrm{E}-05$ & $1.49 \mathrm{E}-05$ & $6.90 \mathrm{E}-06$ & $2.85 \mathrm{E}-06$ & $1.27 \mathrm{E}-06$ & $6.22 \mathrm{E}-0$ & $3.31 \mathrm{E}-07$ & $1.92 \mathrm{E}-07$ & $1.33 \mathrm{E}-07$ \\
\hline \multicolumn{15}{|l|}{ CO } \\
\hline $320 \mathrm{c} 30 \mathrm{~b} 191$ & 0.85 & $9.12 \mathrm{E}-19$ & $5.41 \mathrm{E}-16$ & $58.84 \mathrm{E}-14$ & $5.71 \mathrm{E}-12$ & $1.87 \mathrm{E}-10$ & $3.55 \mathrm{E}-09$ & $4.41 \mathrm{E}-08$ & $3.92 \mathrm{E}-07$ & $2.67 \mathrm{E}-06$ & $1.46 \mathrm{E}-0$ & $6.74 \mathrm{E}-05$ & $2.81 \mathrm{E}-04$ & $1.23 \mathrm{E}-03$ \\
\hline $320 \mathrm{c} 30 \mathrm{~b} 191$ & 1.1 & $9.13 \mathrm{E}-19$ & $5.41 \mathrm{E}-16$ & $8.84 \mathrm{E}-14$ & $5.71 \mathrm{E}-12$ & $1.87 \mathrm{E}-10$ & $3.54 \mathrm{E}-09$ & $4.39 \mathrm{E}-08$ & $3.91 \mathrm{E}-07$ & $2.66 \mathrm{E}-06$ & $1.45 \mathrm{E}-0$ & $6.71 \mathrm{E}-05$ & $2.79 \mathrm{E}-04$ & $1.23 \mathrm{E}-03$ \\
\hline \multicolumn{15}{|l|}{$\mathrm{CO}_{2}$} \\
\hline $320 \mathrm{c} 30 \mathrm{~b} 191$ & 0.85 & $3.79 \mathrm{E}-32$ & $7.55 \mathrm{E}-28$ & |2.04E-24 & $1.31 \mathrm{E}-21$ & $2.89 \mathrm{E}-19$ & $2.76 \mathrm{E}-17$ & $1.37 \mathrm{E}-15$ & $4.06 \mathrm{E}-14$ & $7.93 \mathrm{E}-13$ & $1.10 \mathrm{E}-1$ & $1.17 \mathrm{E}-10$ & $1.04 \mathrm{E}-09$ & $8.92 \mathrm{E}-09$ \\
\hline $320 \mathrm{c} 30 \mathrm{~b} 191$ & 1.1 & $3.80 \mathrm{E}-32$ & $7.56 \mathrm{E}-28$ & $2.04 \mathrm{E}-24$ & $1.31 \mathrm{E}-21$ & $2.89 \mathrm{E}-19$ & $2.75 \mathrm{E}-17$ & $1.36 \mathrm{E}-15$ & $4.04 \mathrm{E}-14$ & $7.89 \mathrm{E}-13$ & $1.10 \mathrm{E}-1$ & $1.17 \mathrm{E}-10$ & $1.03 \mathrm{E}-09$ & $8.89 \mathrm{E}-09$ \\
\hline
\end{tabular}

For the gas pressure calculations, a buffer porosity of 50\% is used, and the fuel kernel porosity is ignored. The volume of voids in the fuel-buffer regions per pebble $V_{v}=7.99 \times 10^{-7} \mathrm{~m}^{3}$. The average gas pressure in the fuel-buffer region of the pebbles is calculated with the ideal gas equation

$$
\mathrm{p}=\left(\mathrm{N} / \mathrm{V}_{\mathrm{v}}\right) \mathrm{kT},
$$

where $\mathrm{N}=$ total number of molecules per pebble, $\mathrm{k}=$ Boltzmann constant $=1.381 \times 10^{-23} \mathrm{~J} / \mathrm{K}$, and $\mathrm{T}=$ temperature $(\mathrm{K})$.

For pure $\mathrm{UO}_{2}$ fuel $(\mathrm{c}=0)$ the predicted pressures of $\mathrm{CO}$ and $\mathrm{CO}_{2}$ are shown vs. temperature in Figure 2-26. $\mathrm{CO}_{2}$ makes a significant contribution to the total pressure at $\mathrm{T} \leq 1100 \mathrm{~K}$. The maximum total pressure of $\left(\mathrm{CO}+\mathrm{CO}_{2}\right)$ at $191 \mathrm{MWd} / \mathrm{kg}$ and $200 \mathrm{~K}$ and is $154 \mathrm{MPa}$. Figure 2-27 shows the total pressure vs. temperature replotted on a linear scale, with the peak $\mathrm{CO}_{2}$ pressure shown for comparison (bottom curve). 


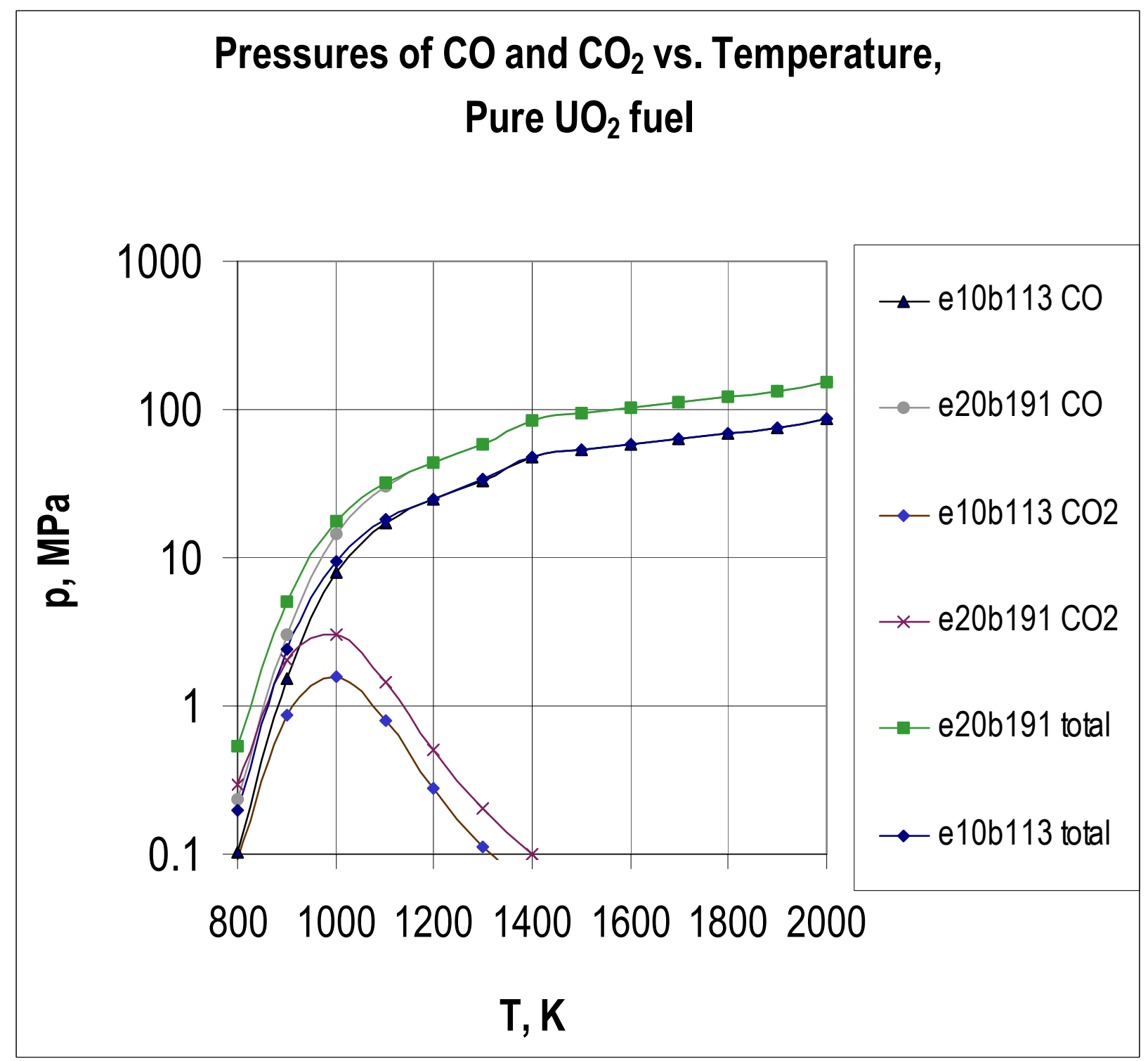

Figure 2-26. Pressures of $\mathrm{CO}$ and $\mathrm{CO}_{2}$ in pure $\mathrm{UO}_{2}$ fuel vs. temperature, at various enrichments and burnups. 


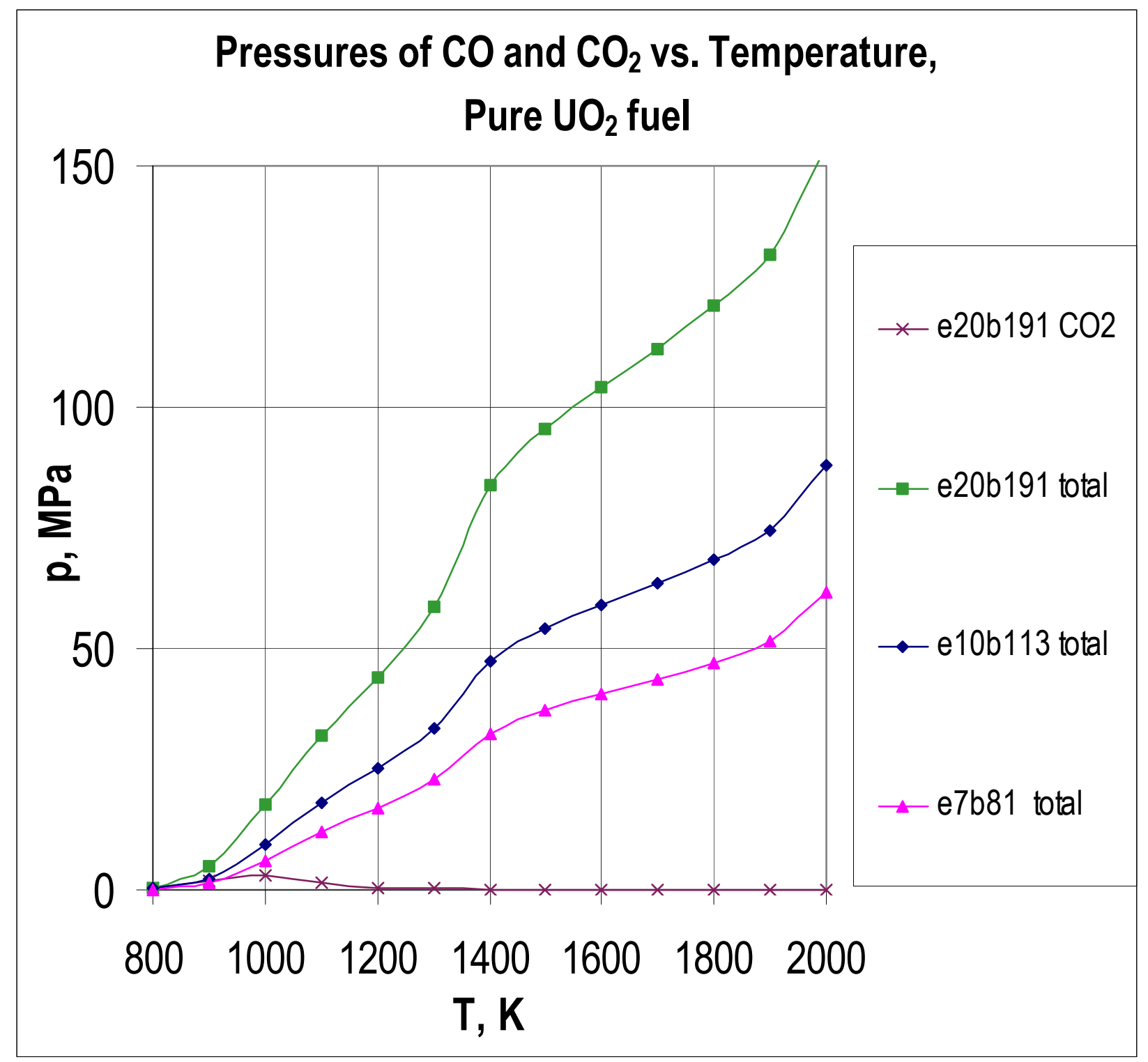

Figure 2-27. Total pressure of $\mathrm{CO}+\mathrm{CO}_{2}$ in pure $\mathrm{UO}_{2}$ fuel vs. temperature, for various enrichments and burnups. The bottom curve shows the peak $\mathrm{CO}_{2}$ pressure.

For UCO fuel with $\mathrm{c}=30 \%$ the predicted $\mathrm{CO}$ pressure is shown vs. temperature in Figure 2-28. The cases with low enrichment have more fissions in plutonium, hence higher resultant CO pressures. The pressure of $\mathrm{CO}_{2}$ is negligible and the total pressures are much lower than for pure $\mathrm{UO}_{2}$ fuel. Figure 2-29 shows the variation of CO pressure with burnup for the same case $(e=20 \%, c=30 \%)$. The peak pressure at $2000 \mathrm{~K}$ and maximum burnup is $26 \mathrm{MPa}$. The $\mathrm{CO}$ pressure is dependent on fuel particle design. For other fuel particle designs the general trends of pressure variation with enrichment, $\mathrm{UC}_{2}$ fraction, burnup, and temperature would be qualitatively similar, but with different magnitudes. 


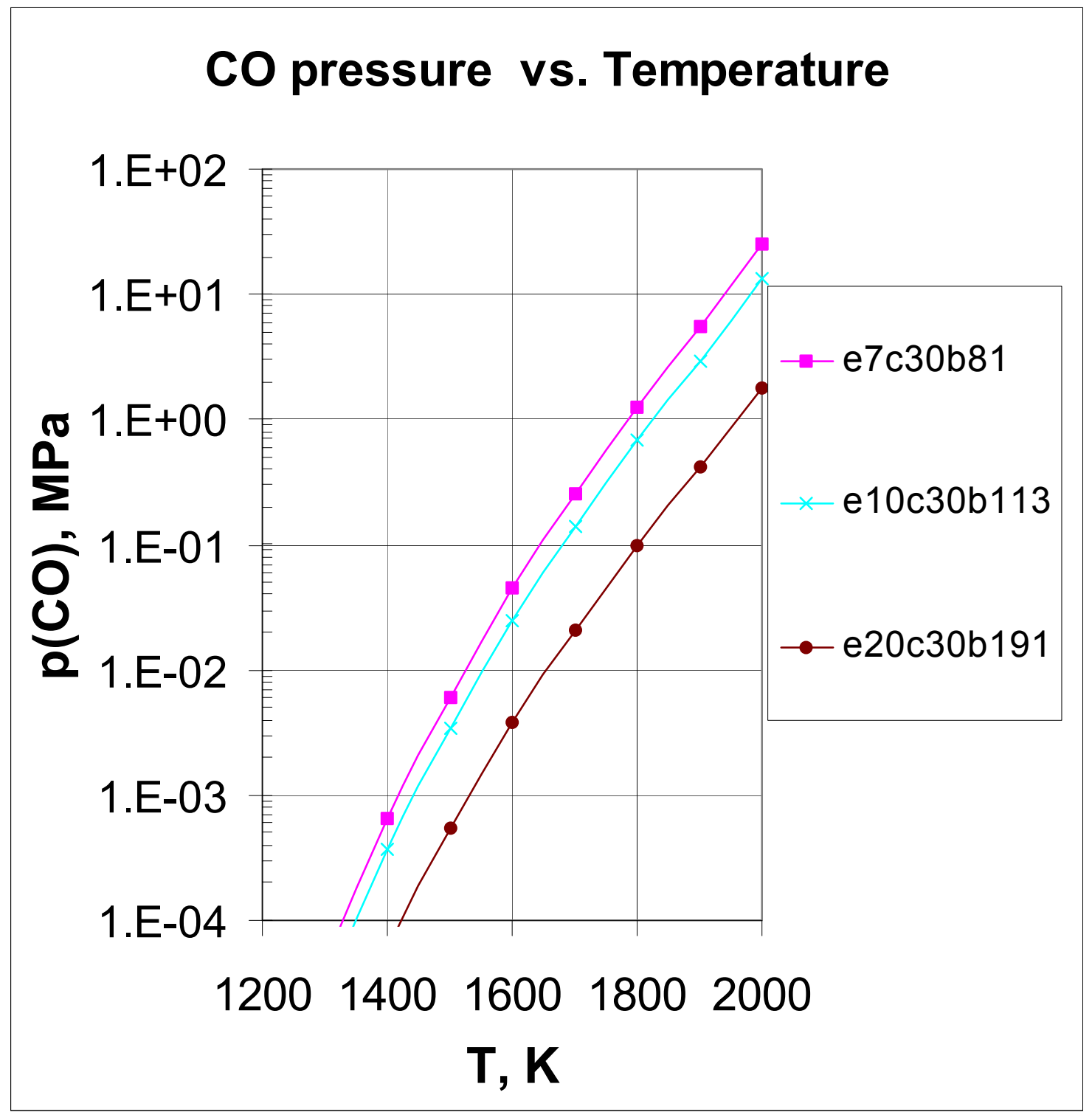

Figure 2-28. CO pressure vs. temperature in UCO fuel with $\mathrm{c}=30 \%$ vs. temperature, at various enrichments and burnup values. 


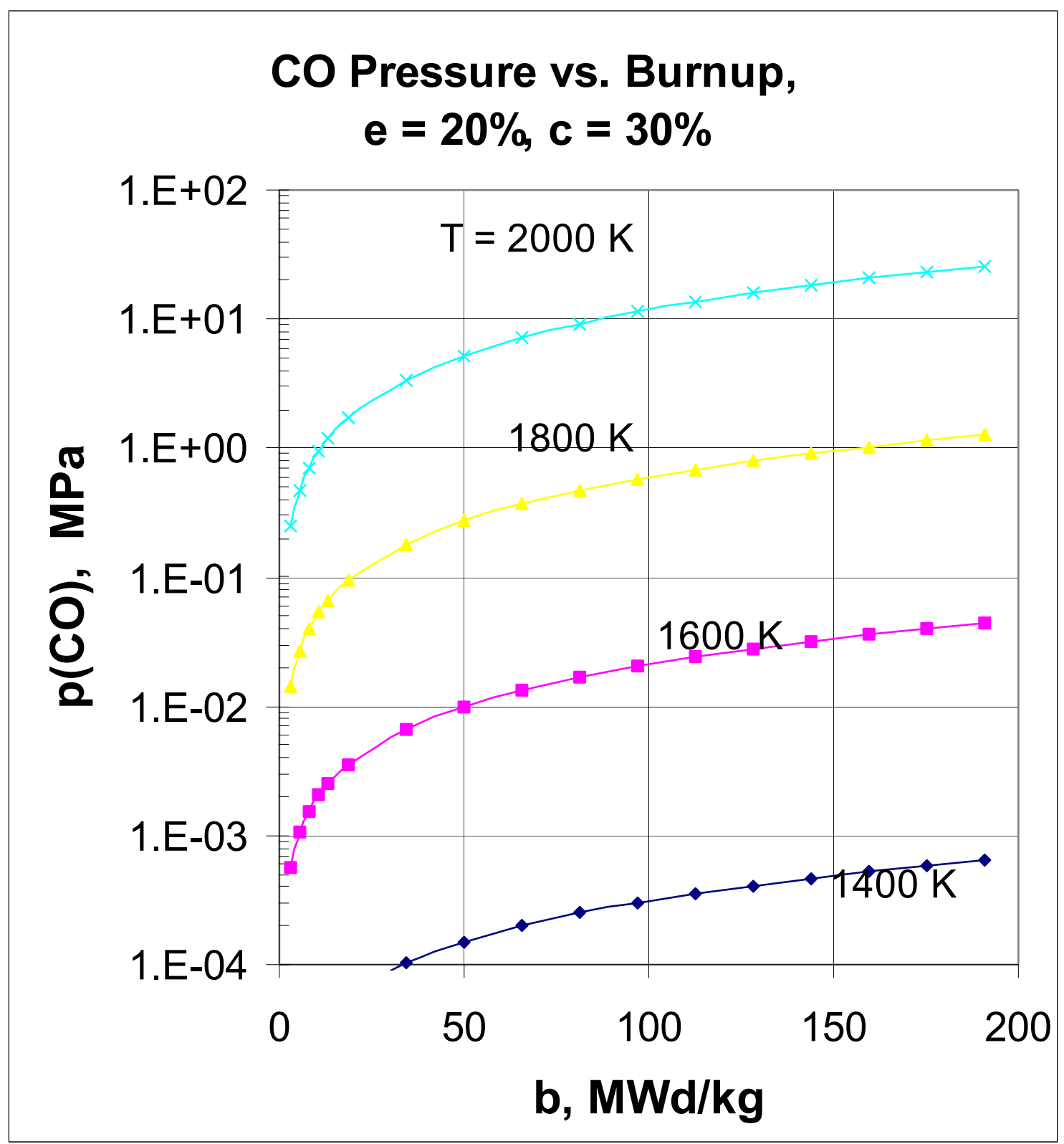

Figure 2-29. CO pressure vs. burnup in UCO fuel with e $=20 \%, \mathrm{c}=30 \%$, at various temperatures.

Using the yield Y (molecules CO per fission), the CO pressure can be estimated with the equation

$$
\mathrm{p}=\mathrm{Y} \mathrm{B}_{\mathrm{a}}\left(\mathrm{m}_{\mathrm{p}} \mathrm{N}_{\mathrm{av}} / \mathrm{M}\right) \mathrm{kT} / \mathrm{V}_{\mathrm{p}}
$$

where $B_{a}=$ atomic burnup fraction (= fissions per heavy metal fuel atom), $m_{p}=$ mass of heavy metal fuel per fuel particle (gram), $\mathrm{N}_{\mathrm{av}}=$ Avogadro number, $\mathrm{M}=$ average mass of heavy metal fuel (=237.7 gram for $10 \%$ enriched uranium), $\mathrm{k}=$ Boltzmann constant, $\mathrm{T}=$ temperature, and $\mathrm{V}_{\mathrm{p}}=$ void volume per fuel 
particle. For the example fuel design described in the Introduction with $50 \%$ buffer porosity the void volume per particle $\mathrm{V}_{\mathrm{p}}=5.3 \times 10^{-11} \mathrm{~m}^{3} /$ particle, there are 9 grams $(\mathrm{U})$ per pebble, and $\mathrm{m}_{\mathrm{p}}=6 \times 10^{-4} \mathrm{~g}$ (U)/particle. For a pure $\mathrm{UO}_{2}$ fuel case with $\mathrm{e}=10 \%, \mathrm{~b}=112.6 \mathrm{MWd} / \mathrm{kg}\left(\mathrm{B}_{\mathrm{a}}=0.1189\right)$, and $\mathrm{T}=2000 \mathrm{~K}$, the yield is 0.992 molecules (CO)/fission. From Equation (18) we calculate $\mathrm{p}=93 \mathrm{MPa}$. The corresponding point "e10b113" at T = $2000 \mathrm{~K}$ of Figure 2-27, based on HSC code values and Equation (17), has a value of $88 \mathrm{MPa}$. The two values differ by $5 \%$, which is within the uncertainty range of algorithm (15).

Assuming $100 \%$ fission gas release, the combined pressure of the noble gas fission products $(\mathrm{Xe}+\mathrm{Kr})$ is shown vs. burnup in Figure 2-30. This pressure varies linearly with temperature and burnup, but varies negligibly with $\mathrm{UC}_{2}$ fraction and enrichment. The peak pressure for these cases at $2000 \mathrm{~K}$ is about 47 $\mathrm{MPa}$. The total pressure in a fuel capsule would be the sum of the partial pressures of $\mathrm{Xe}, \mathrm{Kr}, \mathrm{CO}$, and $\mathrm{CO}_{2}$, which is about $200 \mathrm{MPa}$ for the maximum case considered here. This extreme case is near the pressures at which fuel particle lifetime could be endangered. The relationship between irradiation, stresses, materials properties, and fuel particle lifetimes is discussed by Martin (2001 and 2002). 


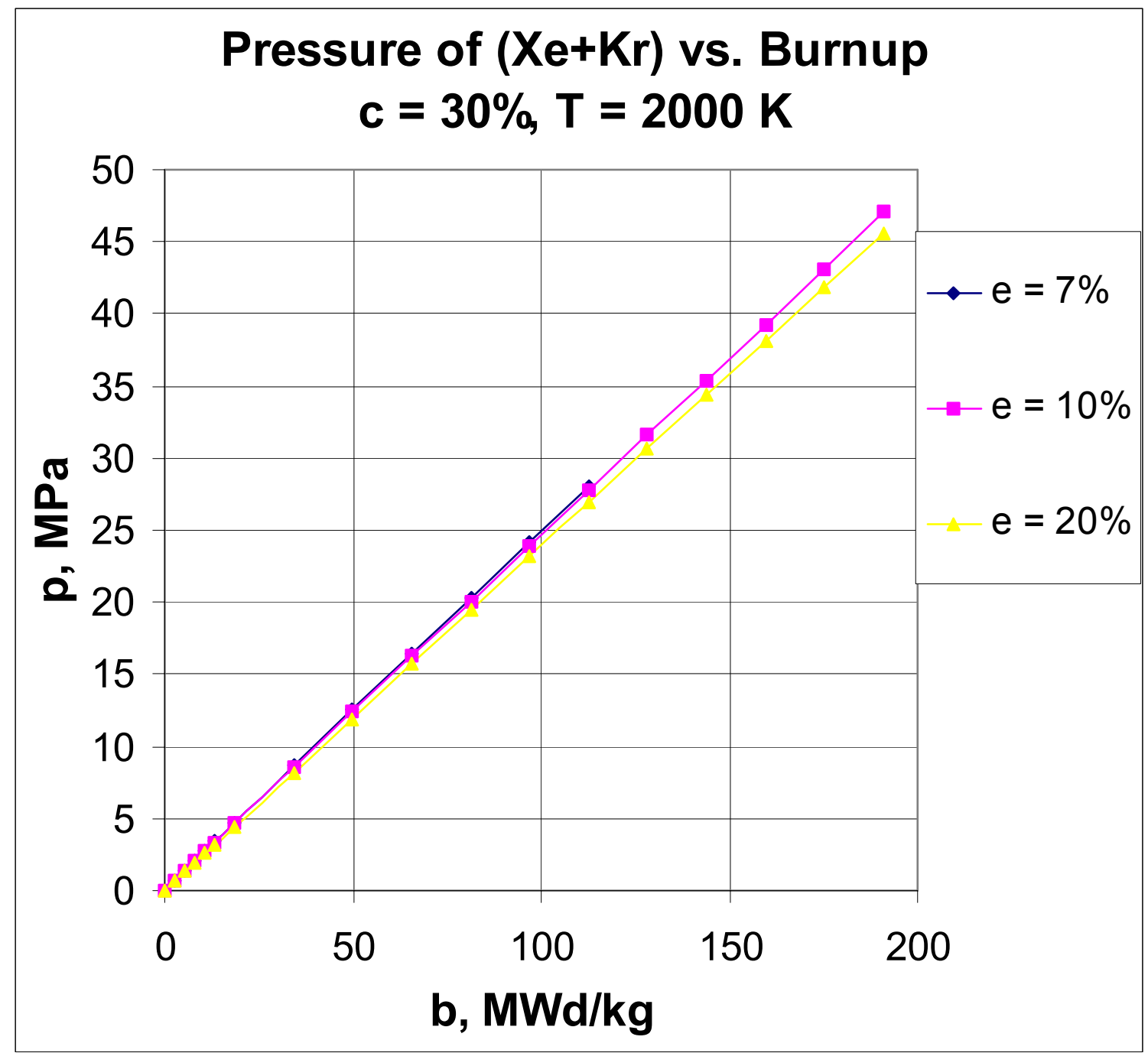

Figure 2-30. Pressure of $(\mathrm{Xe}+\mathrm{Kr})$ vs. burnup at $\mathrm{c}=30 \%, \mathrm{~T}=2000 \mathrm{~K}$, various enrichments.

\subsection{Contribution to the PARFUME Code}

During his visit to the INEEL, Dr. David Martin gave a presentation on gas reactor fuel particle analysis concerning stress modeling issues, material properties, coating layer behavior, kernel-buffer interaction, etc. He also described methodology, input, and output for the STRESS3 and STAPLE codes, which he uses to predict particle failure probabilities for irradiation experiments on fuel particles. He used the STRESS3/STAPLE codes to model performance of the fuel particles of the NPR-1 and HRB-21 irradiations, and documented his calculations that are presented in the appendix. The INEEL is assessing the information obtained and the results of his predictions in developing the PARFUME code. 


\subsection{Summary and Conclusions}

After adjustment of the chemical property databases, the HSC and FACTSAGE codes give comparable predictions of $\mathrm{CO}$ generation in fuel, and HSC was chosen for the main computations.

As free oxygen is released by fission of $\mathrm{UO}_{2}$, it is strongly bound by $\mathrm{Y}$ and lanthanide fission products, but they can only bind about 0.77 oxygen atoms per fission. Uranium from $\mathrm{UC}_{2}$ can bind additional oxygen. As the $\mathrm{UC}_{2}$ is used up, then the fission products $(\mathrm{Zr}, \mathrm{Sr}, \mathrm{Ba}, \mathrm{Eu})$ can bind about 0.71 atoms oxygen per fission. As these elements become oxidized, carbon can oxidize to form $\mathrm{CO}$, especially at high temperatures. Thus, $\mathrm{CO}$ formation becomes appreciable at high burnups and temperatures, especially if little $\mathrm{UC}_{2}$ is present in the fuel. If the fuel were entirely $\mathrm{UC}_{2}$, then the lanthanides would not oxidize, and they could migrate to the $\mathrm{SiC}$ layer and attack it chemically. Therefore either $\mathrm{UO}_{2}$ or some other source of oxygen is needed in the fuel-buffer region to immobilize the lanthanides.

The equilibrium computations used input quantities of $\mathrm{UO}_{2}, \mathrm{UC}_{2}, \mathrm{Pu}, \mathrm{O}_{2}, \mathrm{C}$, and 12 fission product groups, for which there are 241 possible output substances. The equilibria were computed for 5 values of enrichment, 8 values of $\mathrm{UC}_{2}$ fraction, 5 values of burnup, and 18 temperatures. The predicted $\mathrm{CO}$ concentrations varied strongly with temperature, but weakly with burnup, enrichment, and $\mathrm{UC}_{2}$ fraction (except at very high or very low fractions). There is also a substantial yield of $\mathrm{CO}_{2}$ in pure $\mathrm{UO}_{2}$ fuel, but not in UCO fuel. At T $>1500 \mathrm{~K}$ the ability of lanthanides to bind oxygen decreases, so the yield of CO could exceed simplified estimates that assume firm binding by lanthanides at all temperatures.

The HSC predictions of CO yield per fission were compared with theoretical estimates of CO yield by Proksch (1982) and with empirical algorithms for CO release rates measured by Horsley (1976), by Proksch (1982), and by Kovacs (1985). The HSC predictions are consistent with the theoretical estimate for trivalent lanthanides, but higher than the empirical release rates. This difference may be due to two factors: (1) the difference between yield (predicted by HSC) and release from fuel (measured experimentally). (2) limited mobility of oxygen could reduce the actual $\mathrm{CO}$ production below the value predicted by the HSC computations, which assume infinite mobility of oxygen in the fuel-buffer region.

The pressure of $(\mathrm{Xe}+\mathrm{Kr})$ varies linearly with burnup and temperature, reaching $47 \mathrm{MPa}$ at $\mathrm{T}=200 \mathrm{~K}$ and $\mathrm{b}=191 \mathrm{MWd} / \mathrm{kg}$ for the current fuel particle design. In pure $\mathrm{UO}_{2}$ fuel the $\left(\mathrm{CO}+\mathrm{CO}_{2}\right)$ pressure at $\mathrm{e}=$ $20 \%, \mathrm{~b}=191 \mathrm{MWd} / \mathrm{kg}$, and $\mathrm{T}=2000 \mathrm{~K}$ is about $150 \mathrm{MPa}$. When $30 \% \mathrm{UC}_{2}$ is added to the fuel, $\mathrm{CO}_{2}$ pressure is negligible, and the $\mathrm{CO}$ pressure for this extreme case is reduced to about $26 \mathrm{MPa}$. 


\section{REACTOR SAFETY AND THERMAL HYDRAULICS MODELING}

\subsection{Introduction}

This year we focused on adding more detail to our MELCOR model of a pebble-bed reactor, namely in the areas of the lower graphite reflector, the outer graphite reflector region between the helium inlet channel and the reactor pressure vessel including the helium bypass flow annulus. A model of the reactor cavity cooling system (RCCS) was also added to better model the reactor decay heat removal capability. In addition a new graphite oxidation correlation for a highly engineered carbon fiber composition, based on measurements at the INEEL was added to MELCOR code in order to obtain some idea how sensitive the calculated results are to the rate of graphite oxidation. We have just located the actual oxidation rate for the German reflector graphite. We will study this further next fiscal year. The new additions to the model and the model results will be discussed in the following subsections

Some of the results to be discussed below were given in a paper presented at the HTR-2002 $1^{\text {st }}$ International Topical Meeting held in Petten, Netherlands on April 22-24, 2002. The title of the paper is Studies on Air Ingress for Pebble-Bed Reactors and is attached in its entirety in the Appendix.

\subsection{MELCOR Model}

A basic description of the MELCOR pebble-bed reactor model was presented in section 4.1.3 of the FY 2001 Modular Pebble-Bed Reactor Project annual report (Terry et al. 2001). Comparing Figure 3.1 to Figure 3.10 of last year's report, we see that three additional layers of control volumes representing the helium bypass flow annulus (300 series volumes) and the reactor cavity air (400 and 600 series volumes) between the reactor pressure vessel (RPV) and the vault wall have been added to the model. Heat removal panels that are a part of the reactor cavity cooling system (RCCS) are assumed attached to the vault wall facing the RPV. The RCCS is a passive heat removal system that relies upon both radiation and natural convection heat transfer to remove the decay heat from the reactor in the event of a loss of coolant accident. The natural convection flow in the region between the RPV and cooling panels is induced by buoyancy forces in the air as a result of the temperature difference between the RPV and the 
cooling panels. For the series of calculations reported in this section it was assumed that the cooling panels have enough heat removal capability to maintain the panel surface temperature at $27{ }^{\circ} \mathrm{C}$.

The heat structures used in the MELCOR model to model the heat conduction and radiation heat transport in the reactor fuel, the heat transport from the fuel through the graphite reflectors walls and finally through the reactor primary vessel walls out to the RCCS cooling panels are illustrated in Figure 3.2. The new heat structures that were added to the model are (1) the lower reflector region below the core (hs226, hs225, hs224, hs223, hs124, hs213, hs212, hs211, hs210 and hs111), (2) the 700 series heat structures representing the core barrel region, (3) the 300 series heat structures representing the primary pressure vessel, (4) and the 400 series heat structures representing the RCCS cooling panels. The lower reflector heat structures were added because it was recognized that the relatively hot lower reflector graphite would consume most of the oxygen in the air inflow from the vault before reaching the core. The numbers presented in parentheses correspond to the control volumes (see Figure 3.1) that the heat 


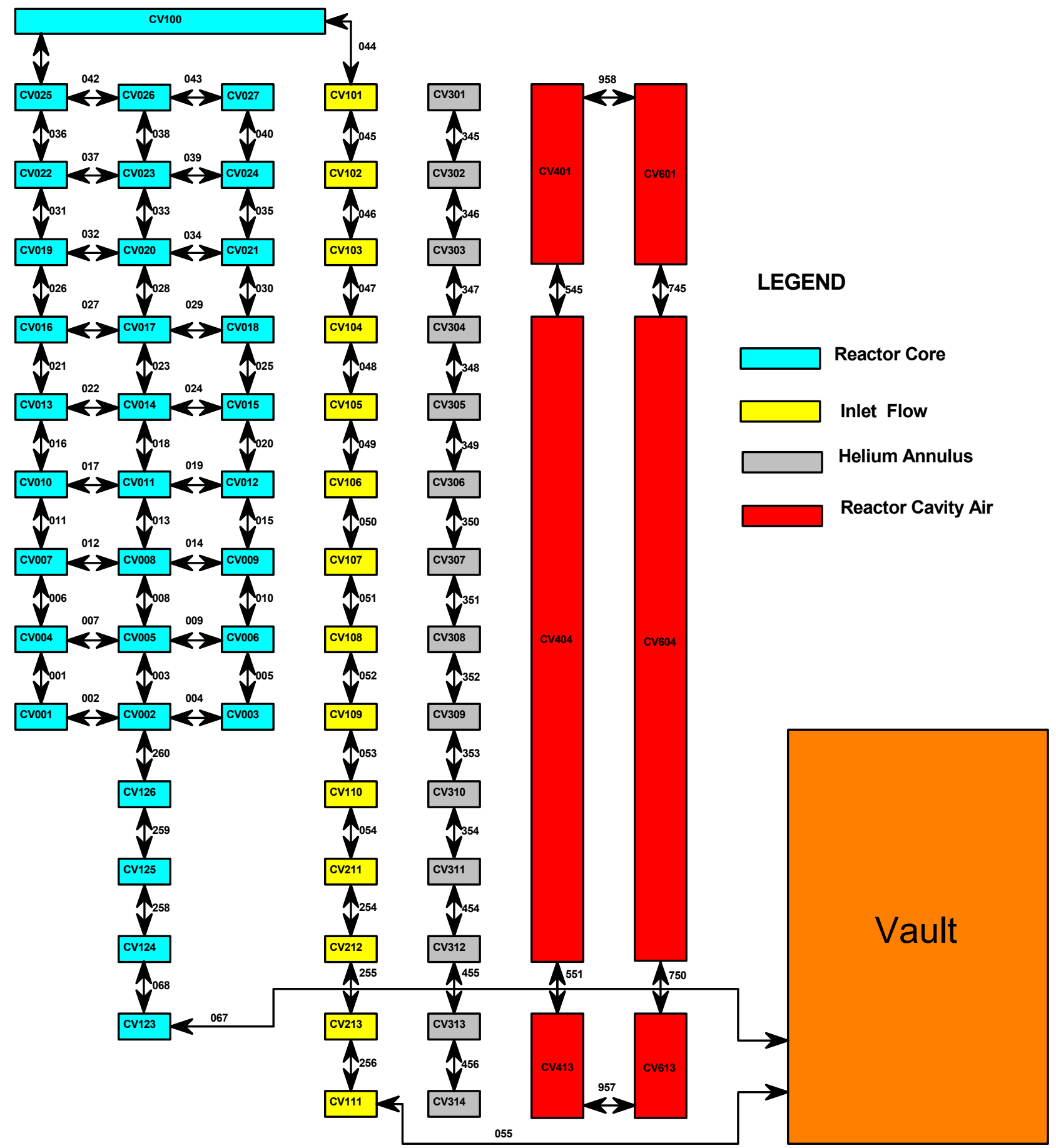

Figure 3.1 Pebble-Bed Control Volume diagram. 


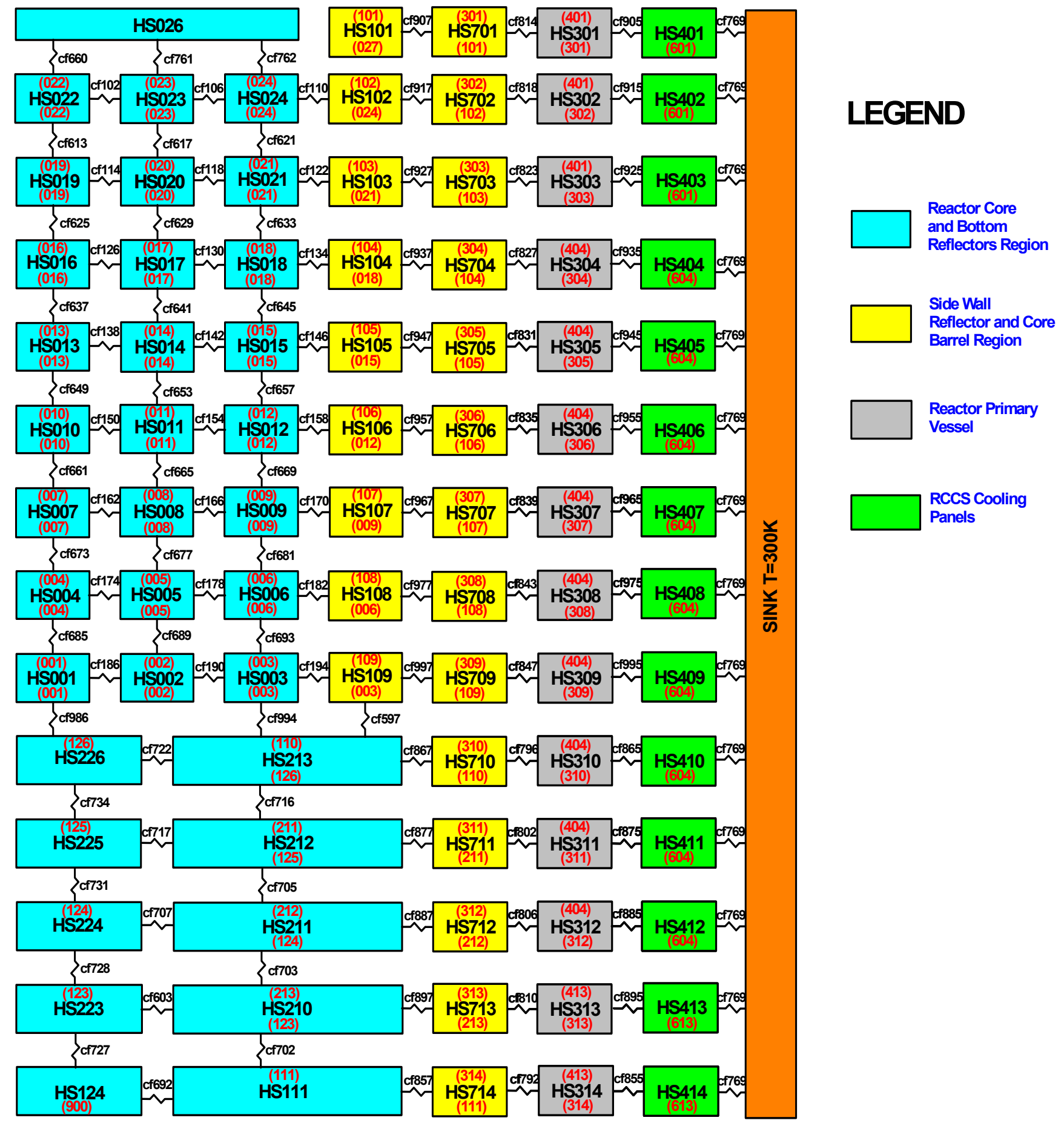

Figure 3.2 Pebble-Bed Heat Structure Diagram. 
structures are connected too. The bottom number corresponds to the control volume on the left and the top number to the control volume on the right. The numbers connecting the heat structures are control function numbers that identifies the control function responsible for the heat conduction and radiation between the various heat structures.

\subsection{New Oxidation Model}

As indicated above, the effect of a different oxidation model was studied with MELCOR. The new reaction rate correlation, generated at the INEEL in support of the Fusion Safety Program, is reported in the reference by Marshall (2002). The reaction rate data were obtained for a test specimen of NB31, a state-of-the-art three-dimensional carbon fiber composite impregnated with pyrocarbon particles. Although the data does not correspond to the fuel and reflector graphite currently being proposed for the pebble-bed reactor concept, it does allow one to get some idea as to how the graphite oxidation rate affects the progression of the oxidation front in the lower reflector and fuel regions of the reactor. The old and new reaction rate data used in the model is shown Figure 3.3. As can be seen in the figure, this graphite is much less reactive at low temperatures $\left(<800^{\circ} \mathrm{C}\right)$.

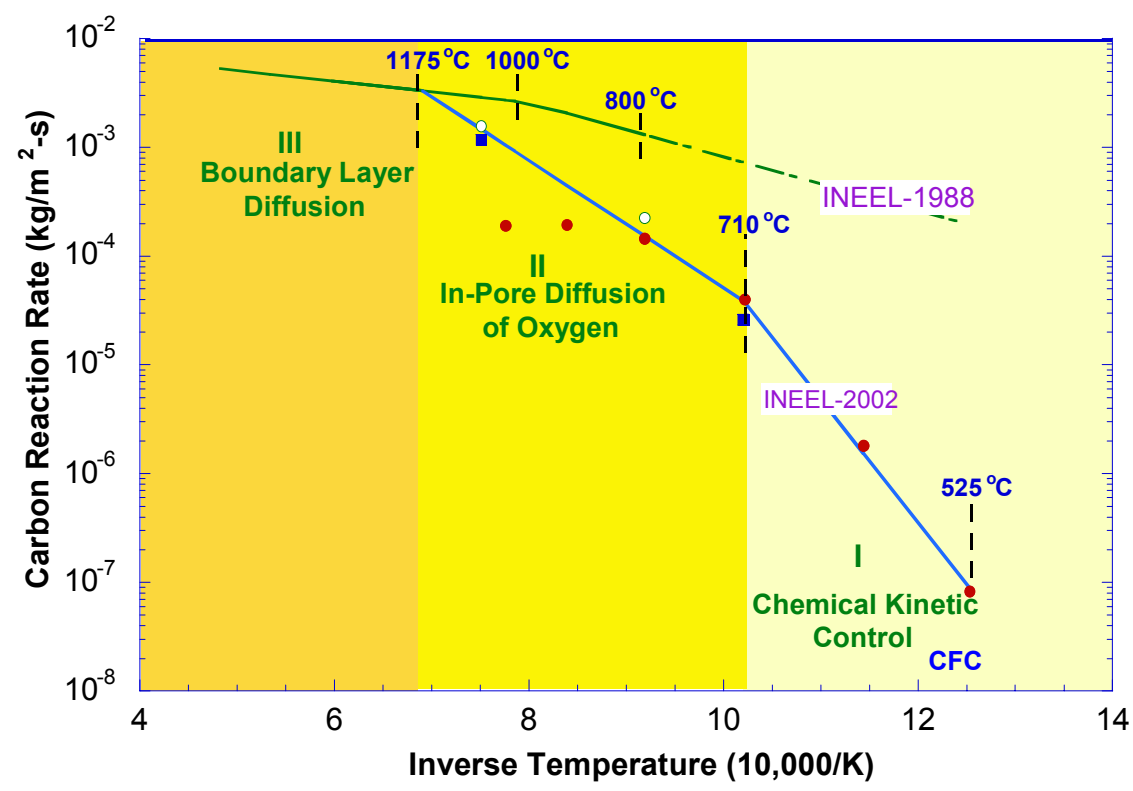

Figure 3.3 Comparison of INEL-1988 and INEEL-2002 carbon-air reaction rates. 
The experimental carbon-air reaction rate data in the above plot clearly show the three different reaction zones as discussed in references (Wichner and Ball 1999, Bews et al. 2001). In zone I the reaction rate is controlled entirely by the chemical kinetics of the reaction. In this zone the graphite is oxidized homogeneously within the pores as well as on the surface of graphite. As indicated in the figure this zone covers the temperature range up to $\approx 700{ }^{\circ} \mathrm{C}$ however, in the literature (Moorman 1999), it has been reported that the transition between zones is not only dependent on temperature but also on the flow rate, material dimension, and the partial pressure of the oxygen in the air. The second zone (intermediate temperature zone) denoted as zone II on the above figure covers the temperature range from approximately 700 to $1200^{\circ} \mathrm{C}$. In this zone the reaction rates are a function of both the chemical kinetics and the in-pore diffusion of the oxygen. The reaction rates in the high temperature zone (zone III) are control by the diffusion of oxygen through the boundary layer adjacent to the outer carbon surface. Because the reaction rates at high temperatures are much larger than those in zones I and II, the reaction between carbon and air occurs entirely on the carbon surface.

The new experimental data generated from the NB31 specimen were confined to the zones I and II whereas the older 1988 data primarily focused on temperatures in zones II and III. The 2002 correlation is an integration of the old and new date such that the three zones are addressed in the correlation. The following equations describe the reaction rates $\left(\mathrm{kg} / \mathrm{m}^{2} \mathrm{sec}\right)$ in the three zones.

\section{- $\quad$ Zone I}

$$
\mathrm{R}_{\mathrm{ox}}=3.2269 \times 10^{7} \cdot \exp \left[-2.6769 \cdot \frac{10000}{\mathrm{~T}}\right]
$$

- Zone II

$$
\mathrm{R}_{\mathrm{ox}}=14.521 \cdot \exp \left[-1.2522 \cdot \frac{10000}{\mathrm{~T}}\right]
$$

\section{- Zone III}

$$
\mathrm{R}_{\mathrm{ox}}=4.07 \times 10^{-9} \cdot \mathrm{T}^{1.5}
$$




\subsection{Results}

The results presented in this section are for the same accident scenario as reported in Terry, 2001. Our focus this year is on understanding the effect of additional modeling detail on the behavior (e.g. lower and upper reflector regions, side wall reflector region, and the modeling of the RCCS) of the system in an air ingress event. The newly configured model was first run with the old INEEL oxidation correlation and with no decay heat removal by natural convection in the space between the RPV and the RCCS cooling panels. The results from this case are presented in Figure 3.4. The first obvious difference is the increase of the delay time for the onset of natural convecting flows in the core. The delay time increases from $\approx$ 90 hours to 210 hours for the new configuration. This is mainly due to the different thermal gradients established in the flow paths from the pipe break to the core i.e., the buoyancy forces are different in the flow loop. In last year's results there was no heating of the fluid in the bottom reflector region, thus the gas temperatures from the pipe break to the beginning of the heated fuel region were isothermal. We also see that adding more detail to the model lowered the peak temperature in the core from $1880{ }^{\circ} \mathrm{C}$ to 1695 ${ }^{\circ} \mathrm{C}$, which is slightly above the current limit of $1650{ }^{\circ} \mathrm{C}$ for the non-release of fission products from the fuel pebbles.

In Figure 3.4, the graphite temperature at the bottom of the lower reflector is $850{ }^{\circ} \mathrm{C}$ when the LOCA is initiated. The temperature of the graphite in this region has decreased to $450{ }^{\circ} \mathrm{C}$ by 210 hours due to the conduction of heat out to the reactor cavity. At this time the onset of natural convection occurs resulting in air inflow from the vault region to the hot core by way of the lower reflector region. Although the lower portion of the lower reflector region is relatively cool at this time, the reaction rate of graphite with oxygen at these temperatures using the INEL-1988 correlation is high, approximately four orders of magnitude higher than the new INEEL-2002 correlation. Thus, MELCOR calculates an immediate increase in the temperature of the lower region of the lower reflector due to the oxidation of the graphite in this region. Over the next 40 hours the graphite temperatures in this region peak at $900{ }^{\circ} \mathrm{C}$ and then steadily decrease for the remainder of the transient. The turn over in temperature is due to the drop off in the partial pressure of oxygen supplied from the vault since the oxidation rate is assumed to also be a linear function of the oxygen partial pressure. The vault is assumed to be a sealed room, thus as oxygen is consumed by the graphite, the oxygen partial pressure in the vault decreases causing less graphite oxidation to take place. 


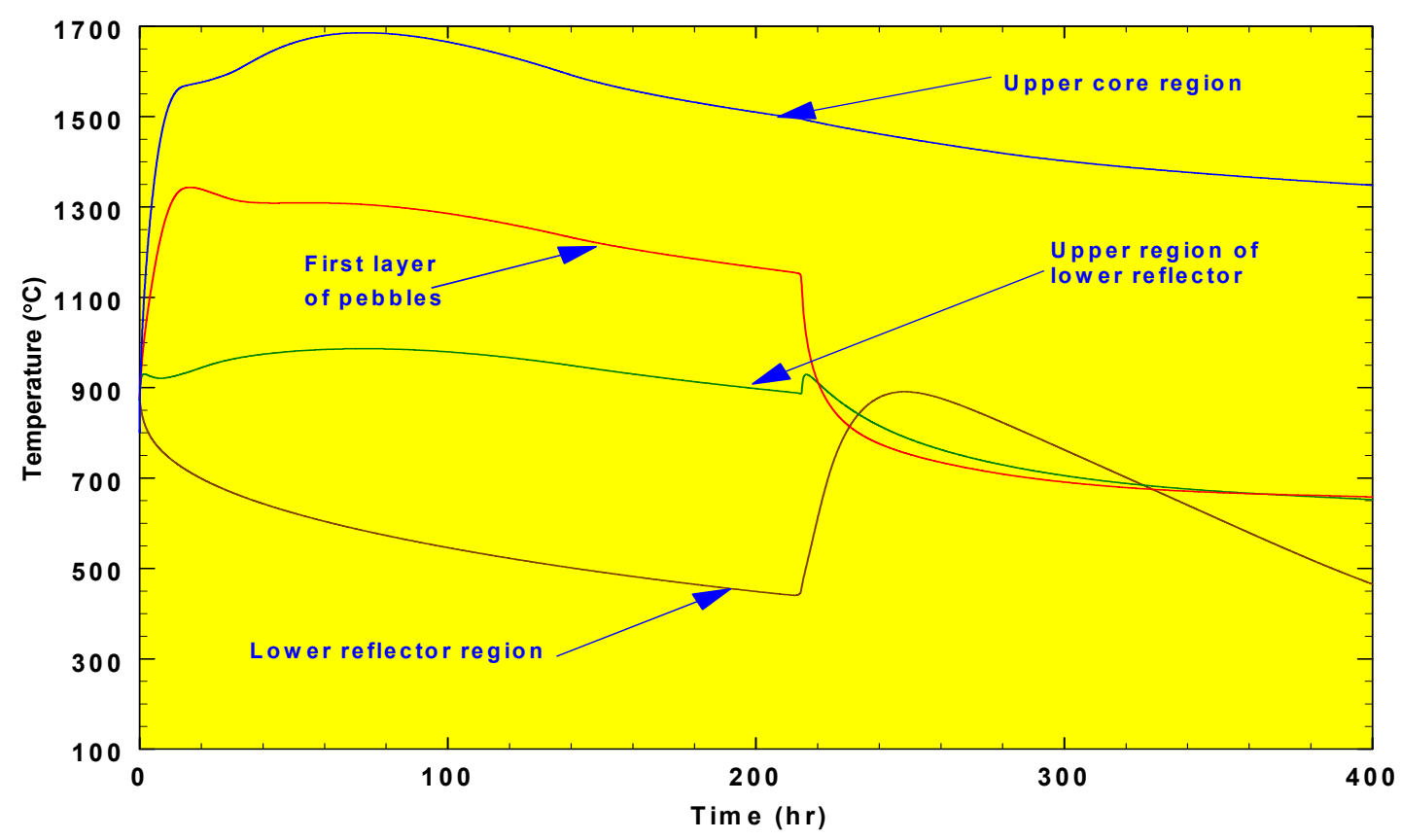

Figure 3.4 Core and lower reflector temperatures using INEEL-1988 correlation.

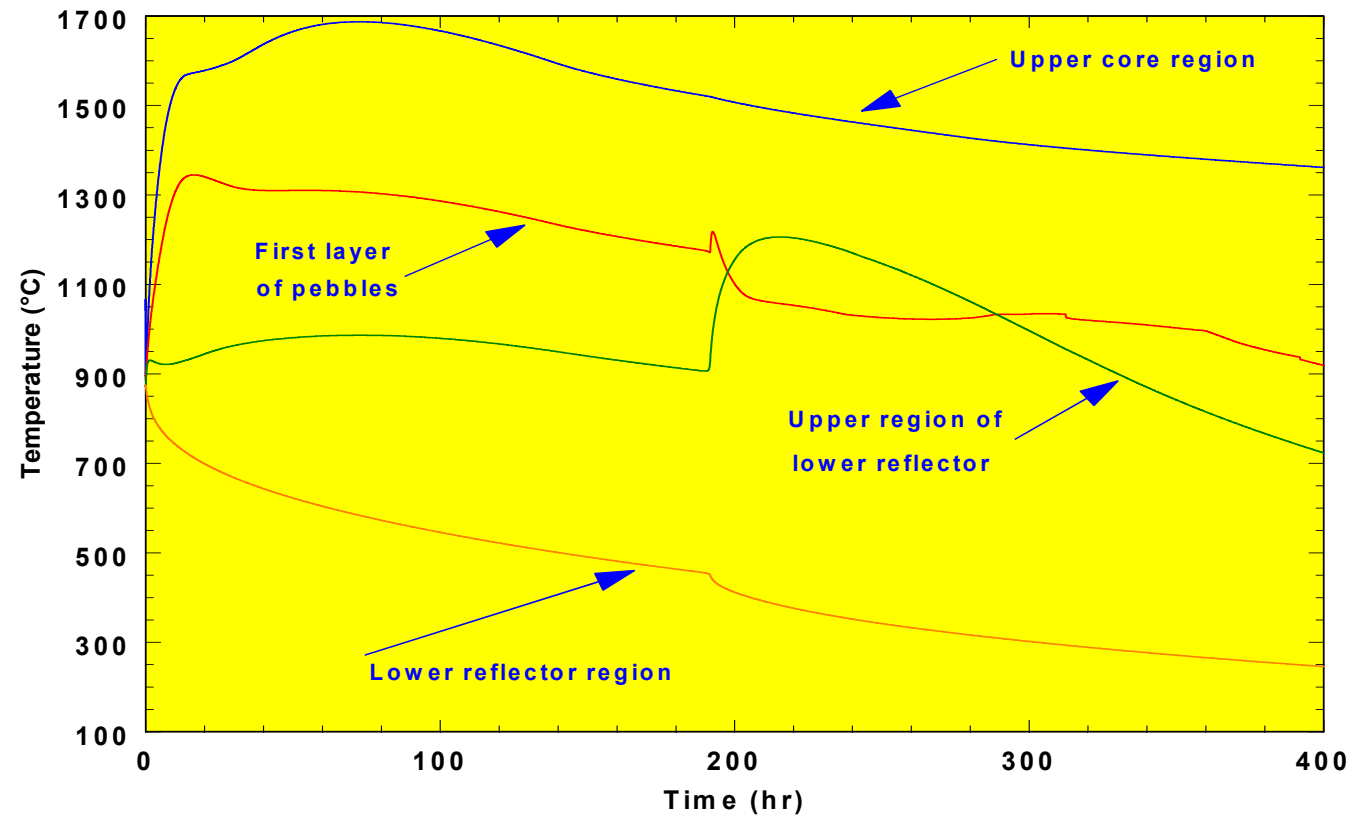

Figure 3.4 Core and lower reflector temperatures using INEEL-2002 correlation. 
The temperature of the graphite in the upper region of the lower reflector, i.e., just below the entrance to the core, remains relatively constant out to 210 hours. At 210 hours the temperature of surface temperature of the graphite in this region increases slightly from $900{ }^{\circ} \mathrm{C}$ to $935^{\circ} \mathrm{C}$ over a five-hour period. Then the temperature starts to decrease. This small spike in temperature indicates that there is very little oxygen in the gas when it reaches this level of the lower reflector and after a few hours the graphite at the bottom of the lower reflector region consumes all the oxygen in the incoming air. Examination of the temperature history of the first layer of pebbles in the core suggests no oxidation is occurring in this layer. In fact when natural convection is initiated the temperature of the pebbles in this region immediately experience a cooling effect from the relatively cool $900{ }^{\circ} \mathrm{C}$ gas. At this time and location the pebble temperatures are $1150^{\circ} \mathrm{C}$. The pebble temperatures experience a $200{ }^{\circ} \mathrm{C}$ decrease in temperature in the next 5 hours then the pebble temperatures gradually decrease to $680{ }^{\circ} \mathrm{C}$ by 400 hours.

Figure 3.5 is a plot of graphite temperatures calculated by MELCOR using the new INEEL-2002 graphite reaction rate correlation for the same location as depicted in Figure 3.6. As discussed above the new correlation results in much lower reaction rates at low temperatures. Thus, as expected, the graphite oxidation front has moved up from the bottom of the lower reflector region to the top of the lower reflector region as seen in the figure. The temperature of the bottom reflector region is the same as in Figure 3.4 out to 210 hours. At this time we see a discontinuity in the curve indicating that this region is being cooled by the incoming air i.e., no oxidation is occurring. The temperature curve for the upper region of the lower reflector is the same as in Figure 3.4 out to 210 hours. At 210 hours the temperature curve shows a very rapid increase in the surface temperature indicating that oxidation of the graphite in this region is occurring. The temperature increases up to $1200^{\circ} \mathrm{C}$ then as in the case of bottom reflector region in Figure 3.4 the temperature turns over and begins to decrease. This is again due to the decrease in oxygen partial pressure in the vault as a result of the consumption of the oxygen by the graphite. The temperature of the first layer of pebbles experiences a small spike in temperature indicating that some oxidation of the fuel pebbles is occurring. The oxidation in the core region appears to last only a short time (two to three hours at the most), then the pebbles begin to cool off slowly. The temperature at the top of the core is unaffected by what occurs in the lower reflector region; the temperature curves of the upper core region are identical in the two figures.

Several additional sensitivity studies were conducted to determine what effect variations of different parameters would have on the oxidation of the fuel pebbles and the delay time associated with the onset of natural convection in the core. The effect on the timing of the onset of natural convection is shown in Figure 3.6. All sensitivity results were conducted using the INEEL-2002 oxidation correlation. The case 
labeled no convection in reactor cavity corresponds to the base case as discussed above. The next case considered was the base case with the RCCS operational. As seen in the figure the delay time for the onset of natural convection is decreased by approximately 40 hours.

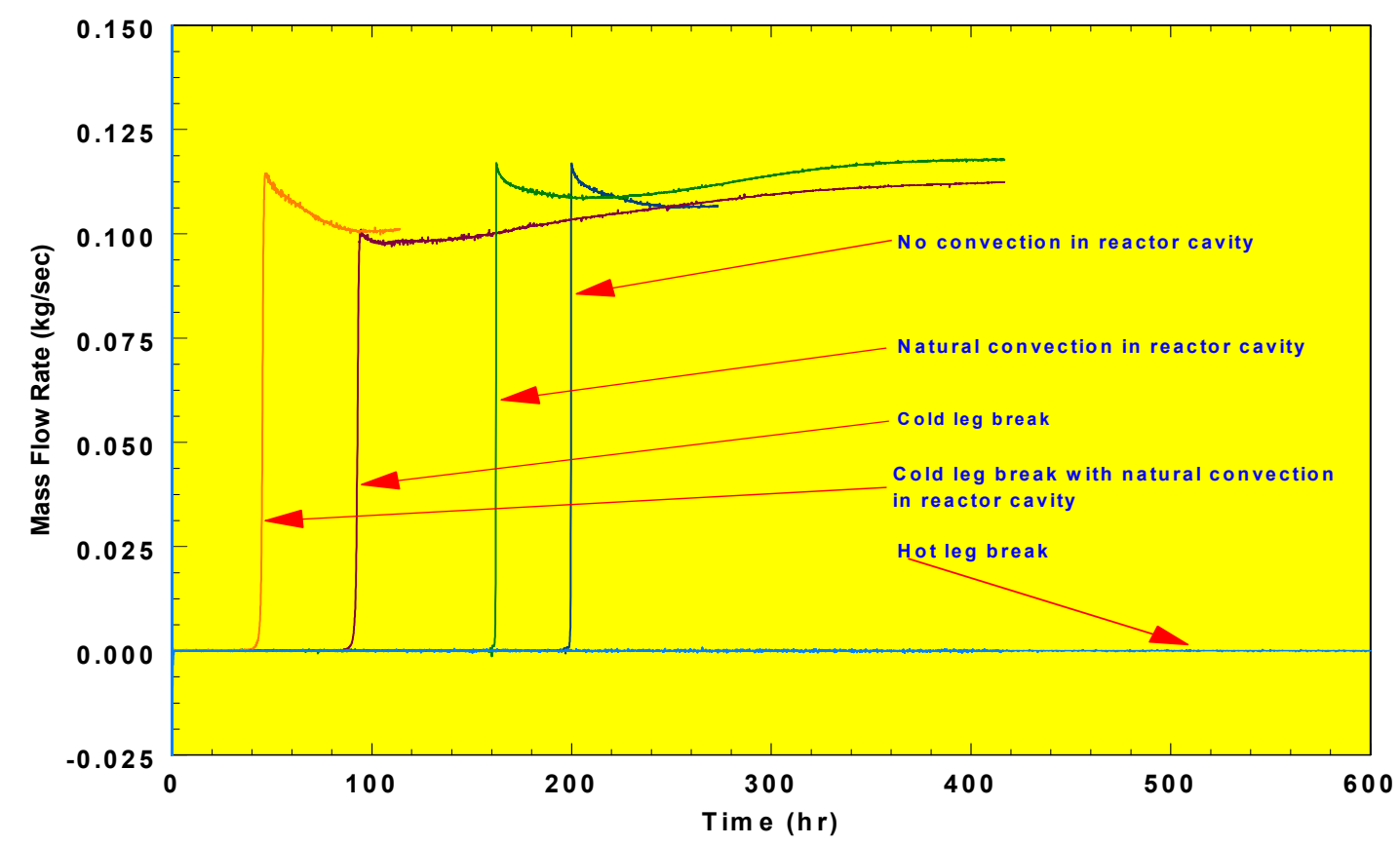

Figure 3.6 The sensitivity of the onset of air ingress.

In the case where only the cold leg of the primary flow loop was assumed to be ruptured, the delay in the onset of natural convection decreases substantially from that of the base case (approximately 200 hours for the base case as opposed to less that 100 hours for the cold leg break). With a cold leg break and the RCCS operational, as with the other cases where the RCCS was operational, the additional cooling of the gas in the inlet flow channel located between the core and RPV via RCCS heat removal causes the onset of natural convection in the primary loop to occur sooner than it would if there were no heat removal by the outside natural convection in the reactor cavity space. Finally, with a hot leg break occurring at the same location as the case where we assumed simultaneous rupture of both the cold leg and hot leg, no indication of natural convective flow of the air from the vault to the core was calculated by MELCOR out to 600 hours.

In all the cases examined to date the mass flow of air into the core increases rapidly from zero to between 0.1 and $0.120 \mathrm{~kg} / \mathrm{sec}$ at the onset of natural convection and remains bracketed between these two values 
for the duration of the transient. The magnitude of the temperature difference between the gas in the core and the gas in the cold leg has a profound effect on the timing of the onset of natural convection in the primary loop.

Figures 3.7 and 3.8 plot the temperatures of the lower reflector region, the first layer of pebbles and the upper core region for the cases of natural convection in the reactor cavity and the cold leg break. The locations of these temperatures correspond to the same locations as discussed in Figures 3.4 and 3.5. Comparing the temperature curves of the upper core region for all cases plotted, little or no change is observed in the upper core temperature history. The peak core temperature for all the cases considered is

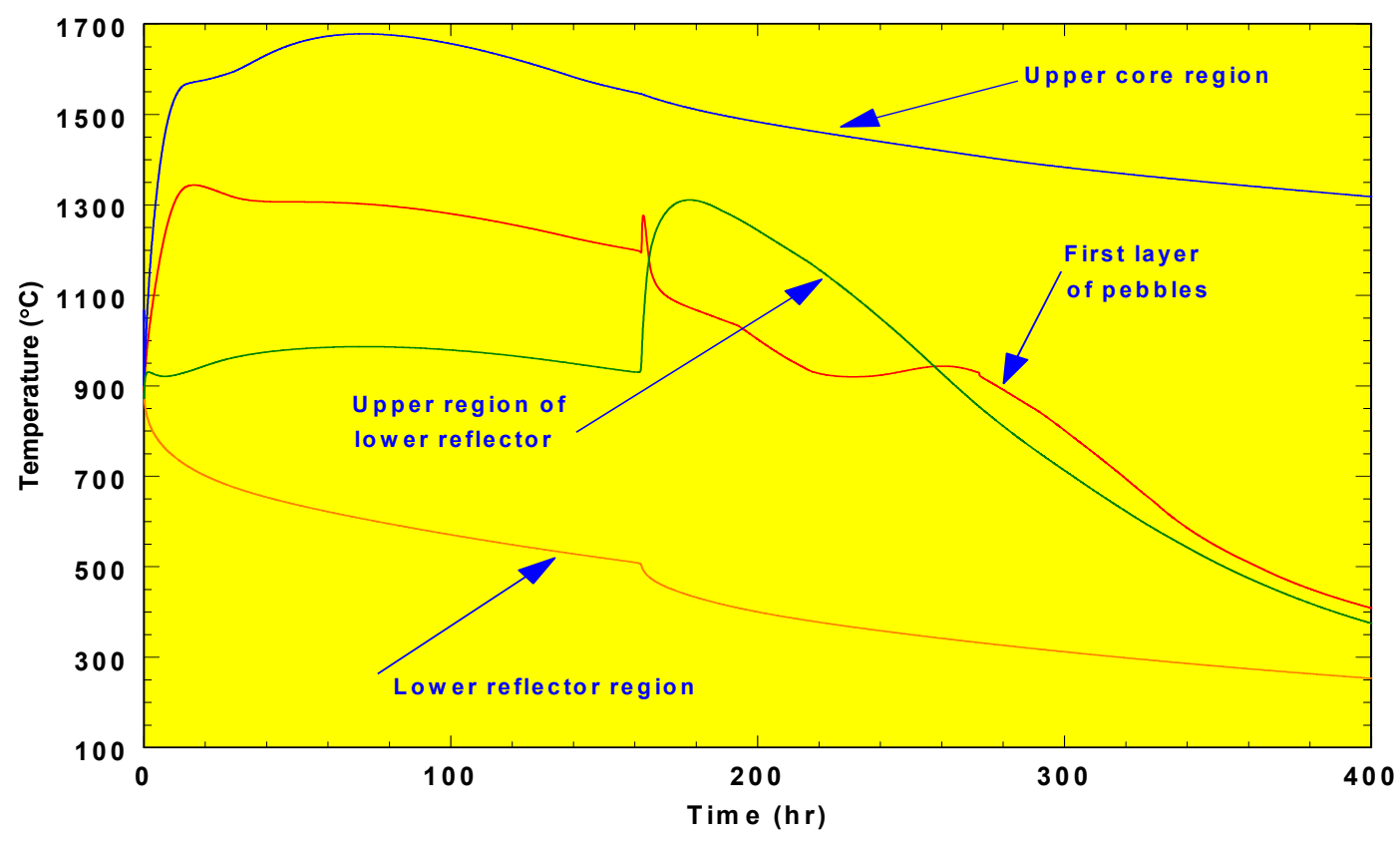

Figure 3.7 Core and lower reflector temperatures corresponding to natural convection in reactor cavity. 


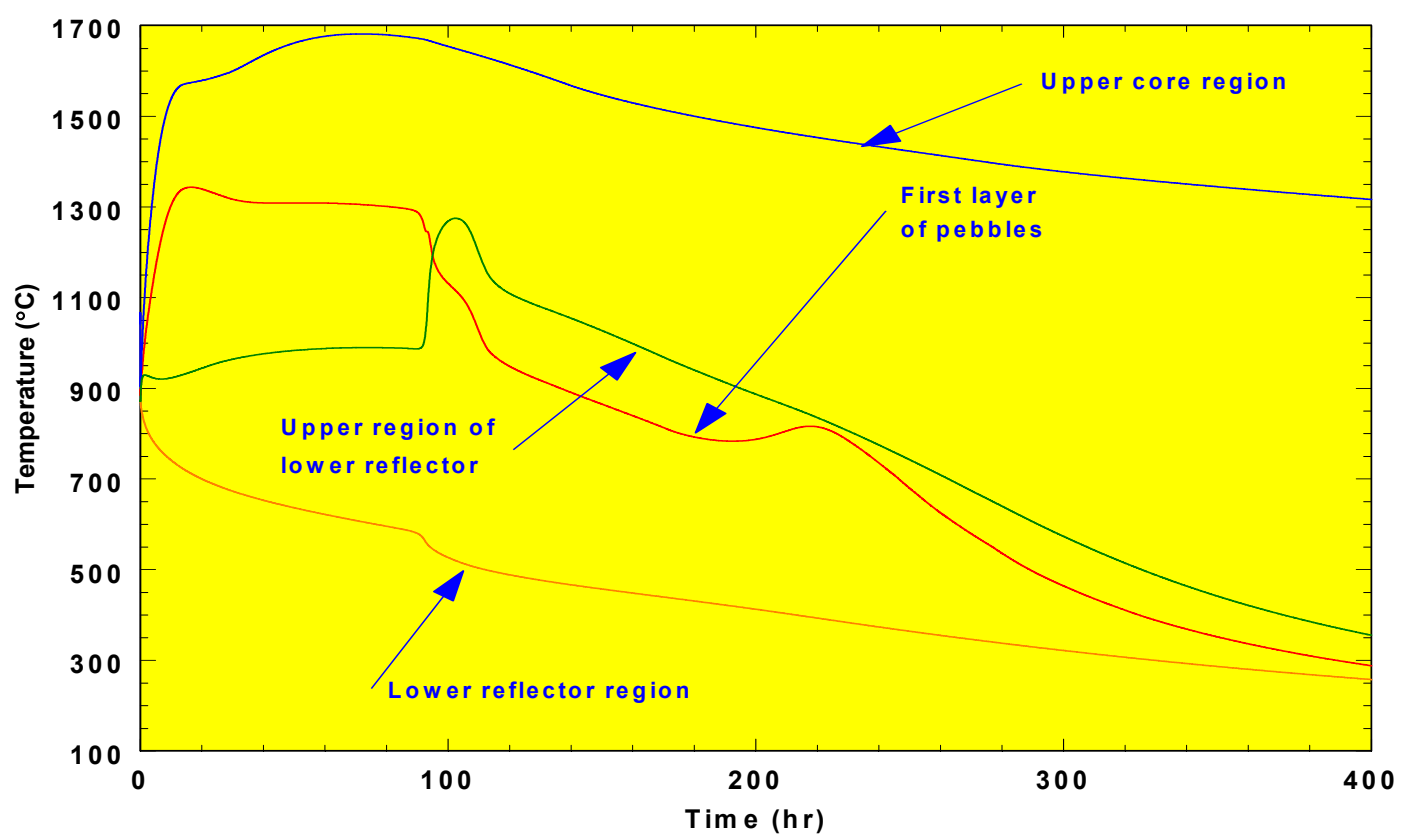

Figure 3.8 Core and lower reflector temperatures corresponding to a cold leg break.

approximately $1690^{\circ} \mathrm{C}$. Due to the large heat capacity of the graphite in the core, very little of the perturbations seen in the lower reflector regions are transported to the upper regions of the core. In the lower reflector region we see the timing of the peak temperatures follow the timing of the onset of natural convection, which is expected. The peak temperature in the lower reflector region is approximately 1300 ${ }^{\circ} \mathrm{C}$ for all the sensitivity cases presented.

Figure 3.9 presents the lower reflector temperature history as a function of the size of the vault. This study was conducted before the new oxidation correlation became available; thus these results were generated using the 1988 INEL oxidation correlation. The vault size was varied from an infinite vault (unlimited supply of fresh air) down to a vault having a volume of $13500 \mathrm{~m}^{3}$. The vaults size for the base case was assumed to be $27000 \mathrm{~m}^{3}$. As shown in the figure, the maximum lower reflector temperature for the $13500 \mathrm{~m}^{3}$ vault case is $750{ }^{\circ} \mathrm{C}$ and it occurs at approximately 265 hours. The onset of natural convection occurs at 240 hours. For the base case the peak temperature is $900{ }^{\circ} \mathrm{C}$ and the onset of natural convection occurs at 210 hours. For the infinite vault volume the peak temperature is $1000{ }^{\circ} \mathrm{C}$ and the onset of natural convection occurs at 130 hours. The difference in peak temperatures and the timing of the onset of natural convection are a function of the concentration of oxygen and nitrogen in the vault 
respectively. As discussed above, the oxidation rate is a function of the partial pressure of oxygen in the feed stream. Thus, with a smaller vault, following He depressurization, the concentration of oxygen in the vault is lower and as the oxygen is consumed the partial pressure decreases at a faster rate. The same can be said for the rate at which the nitrogen diffuses into the core region since the diffusion of nitrogen into the core is dependent on the concentration of nitrogen in the vault. For the case of an infinite vault the concentration of nitrogen and oxygen remain high and are not significantly diluted by the He depressurization. Thus, more oxidation of the graphite occurs in the lower reflector region and nitrogen diffuses into the core region at a faster rate leading to an earlier onset of natural convection. The graphite temperature for the infinite vault case levels off at $950{ }^{\circ} \mathrm{C}$ and stays at this temperature for the duration of the transient. This is due to balance between the heat generated by the oxidation of the graphite and the heat conducted and radiated to the reactor cavity region.

\subsection{Conclusions}

The results have shown that the timing of the onset of natural convection is influenced by the nitrogen concentration in the vault (as seen in Figure 3.9) as well as the temperature difference between the core and the reactor inlet channel. The MELCOR code still need to be validated against experimental data, which is planned in the coming fiscal year.

The results from this year's study indicate that the graphite oxidation rate strongly influences to the location of the oxidation front in the lower reflector and core regions. The correlations used to date do not correspond to the type of graphite being considered for use in the pebble-bed reactor. We have recently obtained from the Germans some oxidation rates that are valid for the type of graphite being identified for use in the fuel pebbles of the pebble-bed reactors. There is some indication that the new oxidation rates may be lower in zone I and II, which may shift the oxidation front up into the core region which from a safety standpoint is undesirable. This new correlation will be added to MELCOR and some of the cases will be rerun to determine the impact on the results. 


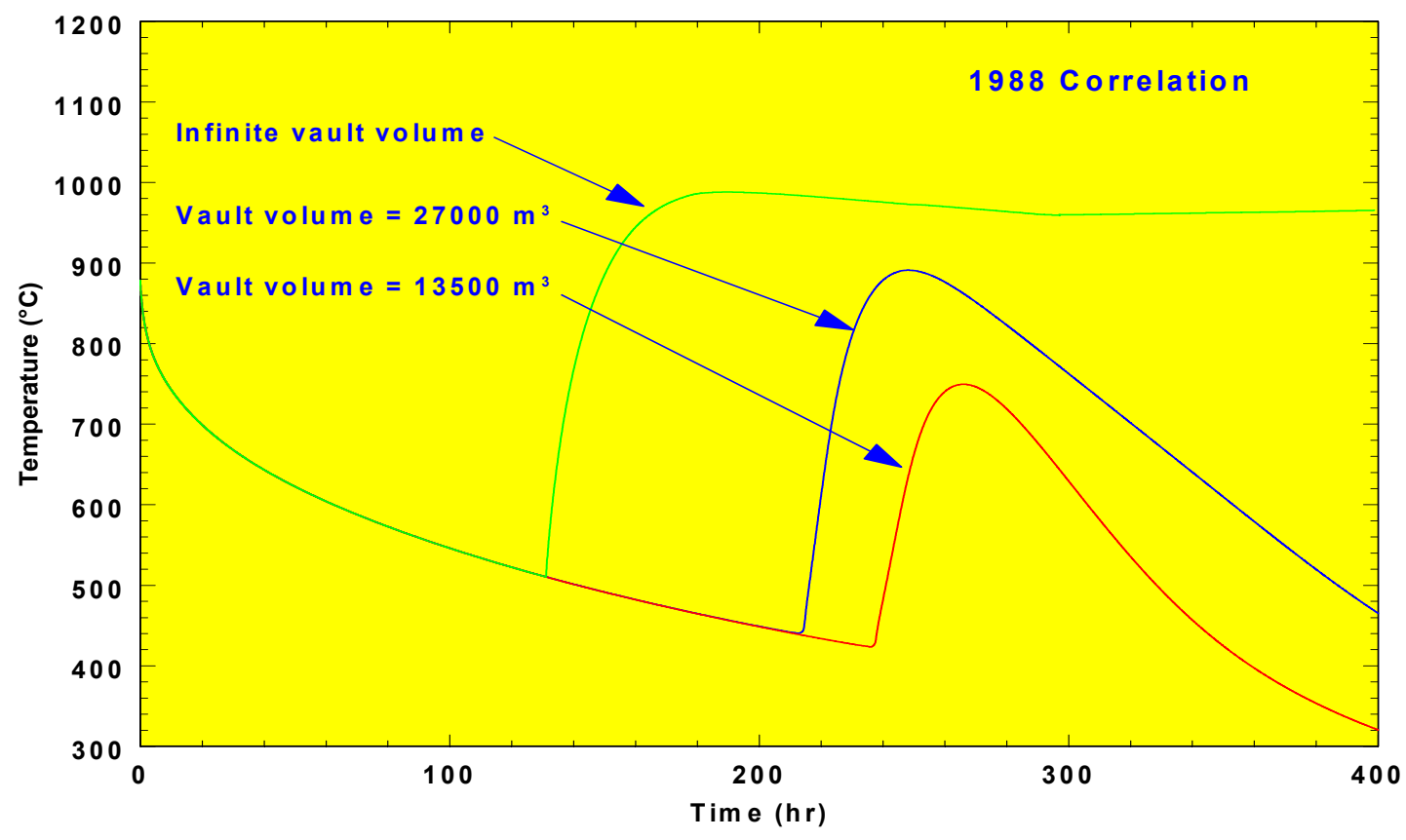

Figure 3.9 Influence of vault volume on lower reflector temperature and onset of natural convection using INEEL 1988 reaction rate correlation 


\section{ACCOMPLISHMENTS IN REACTOR PHYSICS}

The accomplishments of the Pebble-Bed Reactor Physics Team in FY-02 consisted of advancements in the PEBBED code and the application of PEBBED and the Monte Carlo code MCNP to address problems of practical interest in PBR technology. The advancements in PEBBED include development of a threedimensional version, improvements in the matrix formulation of pebble recirculation, enhancements of the depletion solver, and development of heat-transfer models.

A journal article on PEBBED and its underlying mathematical formulation appeared in FY-02:

Terry, W.K., H. D. Gougar, and A. M. Ougouag, 2002, "Direct Deterministic Method for Neutronics Analysis and Computation of Asymptotic Burnup Distribution in a Recirculating Pebble-Bed Reactor," Annals of Nuclear Energy, Vol. 29, pp. 1345-1364.

\subsection{The three-dimensional version of PEBBED}

In FY-01, the two-dimensional PEBBED2 was completed; in FY-02, the three-dimensional PEBBED3 was begun. In PEBBED3, there are two options for the solution of the neutron diffusion equation in general three-dimensional cylindrical geometry. The first option is a standard finite-difference solution; this option is now fully operational. The second option is a nodal solution; this option is still being implemented.

In the nodal option, a technique known as the Coarse-Mesh Finite-Difference method (CMFD(Sutton 1989)) is being applied. In the CMFD technique, the structure of the finite-difference solution is retained, but each term in the seven-point difference equation, which approximates the three-dimensional diffusion equation, is modified by a correction coefficient obtained from the nodal solution. Computation of the correction coefficients does not disrupt the finite-difference algorithm already in place in PEBBED3, since the correction coefficients and all other information from the nodal solution are calculated in subroutines external to the finite-difference algorithm. These subroutines are now being written.

The development of the equations to be coded in these subroutines was accomplished under a separate LDRD project, "Development of a Nodal Method for the Solution of the Neutron Diffusion Equation in General Cylindrical Geometry," LDRD project number NE116, which is a companion project to the 
present one. In that project, a stand-alone nodal solution had been found in FY-01, but it had to be extensively reformulated during FY-02 for implementation in the CMFD scheme.

The advantage of the CMFD approach over the standard finite-difference option is that a much coarser spatial discretization structure can be employed while achieving equal or better accuracy, because the solution within each node, or spatial mesh cell, is analytical. The standard seven-point difference equation is derived by approximating the differential equation as a difference equation; thus, the solution of the difference equation only approaches the exact analytical solution as the spatial mesh cells become infinitesimal in size. The role of the correction coefficients is to correct the difference equation to yield the analytical solution in large mesh cells.

\subsection{Improvements in the matrix formulation of pebble recirculation}

Many pebble-bed core designs feature a two-zone core that may yield improved fuel economy and heat transfer over randomly loaded single-zone cores like the HTR Modul (Frewer and Keller 1985) For example, the South African PBMR (Nicholls 2001) consists of a graphite central zone and a fueled outer zone. The relative sizes of the zones are determined by the relative flow rates of pebbles through the inner and outer loading tubes; there is no physical barrier between the zones. In burnup-dependent twozone cores, pebbles are loaded fresh into one zone and, at some point in their burnup history, transferred to the other zone. Previously, such cores were modeled in PEBBED by manually generating the recirculation matrix "off-line" and reading it into the code. The matrix algorithm was upgraded in PEBBED3 to generate the recirculation matrices internally and automatically for multiple pebble types tracing independent paths through two-zone cores. Complex cores of this type can be modeled and optimized through the manipulation of a few key parameters in the input deck.

The matrix representation of pebble recirculation in PEBBED was reported in the following papers in FY02 :

Gougar, H.D, W. K. Terry, A. M. Ougouag, and C. B. Neill, November 2001, "Matrix Formulation for Automated Modeling of Pebble Circulation in the PEBBED Code," Transactions of the Winter 2001 Annual Meeting of ANS, Reno, NV, Trans. ANS Vol. 85, pp. 108-109. 
Gougar, H.D., W. K. Terry and A. M. Ougouag, 2002, "Matrix Formulation of Pebble Circulation in the PEBBED Code," Proceedings of HTR 2002, 1st International Topical Meeting on High Temperature Reactor Technology (HTR), Petten, Netherlands, April 2224.

\subsubsection{Enhancements of the depletion solver}

In PEBBED2, only one fissile nuclide could be specified in the fuel. The accuracy obtainable in modeling pebble-bed cores with high burnup or multiple fuel types was improved by enabling the code to compute fission yields for up to three fissile isotopes. Most core designs contain uranium-235 as the dominant fuel type, but in high-burnup cores a significant buildup of $\mathrm{Pu}-239$ can occur. Cores containing fertile thorium will build in a large amount of fissile U-233. The fission-product yields of these fuel isotopes differ; thus, different fuel mixes will produce different nuclide distributions and discharge isotopics. PEBBED3 is able to compute and track depletion and buildup in multi-fuel cores.

Computing the equilibrium concentrations of minor actinides and certain fission products of interest became easier in PEBBED3 with the restructuring of depletion chain data. Long chains with multiple branches are handled in a computationally efficient depletion algorithm. Along with the improvement described above, this feature will allow the study of high-burnup and actinide-burning fuel cycles.

\subsubsection{Development of heat transfer models}

A one-dimensional heat transfer model had been implemented in PEBBED2. This model was improved for PEBBED3. The fuel temperature module was improved by adding a graphite thermal conductivity correlation dependent on temperature and neutron fluence. The correlation, developed at Oak Ridge National Laboratory (Vondy 1981), accurately accounts for the thermal conductivity in a pebble given its irradiation history. Coupled with the zone-dependent axial coolant temperature calculation, the correlation gives good approximations of pebble fuel temperature throughout the core and over the history of a given pebble type.

Passive cooling is the predominant safety feature of modular graphite cores. If coolant flow is interrupted, the decay heat must be removed from the core at a rate sufficient to prevent the fuel from exceeding failure temperatures. For reactors with large height-to-diameter ratios, this post-accident fuel temperature was estimated using a one-dimensional (radial) transient heat conduction/radiation model and was shown to be a strong function of the steady-state core power density (Savage 1984). A heat transfer module capable of such simulations has been added to PEBBED3. The module uses the power densities 
computed by the code. This feature allows a core optimization study to include the post-accident peak temperature as one of the parameters in an overall objective function.

\subsubsection{Application of PEBBED and MCNP to address issues of practical importance}

Since PEBBED is being developed as a practical tool with which to answer questions about the performance of real PBRs, it is appropriate to test its capabilities at each stage in its development by applying it to address practical issues. During FY-02, PEBBED was used to investigate questions on the deployment of PBRs in remote locations and on the susceptibility of PBRs to be used for nuclear weapons proliferation.

Three papers and a panel presentation were given in FY-02 on the results of these investigations, and another paper will be submitted to a journal. The paper on deployment of PBRs in remote locations demonstrated the effectiveness of PEBBED by computing the equilibrium critical core of smallest volume as a function of fuel enrichment. This functional relationship was sought because in remote locations the smallest core is likely to be the most economical. The following reference identifies this paper:

Gougar, H.D. and A. M. Ougouag, 2002, "The Modular Pebble-Bed Reactor as Power/Heat Supply for Remote Industrial Operations," CIM-Vancouver 2002, Canadian Institute of Mining, Metallurgy, and Petroleum Annual Conference, Vancouver, British Columbia, CANADA, April 28-May 01.

Our work on nonproliferation of nuclear weapons has shown that the PBR is a poor choice for overt or covert production of nuclear weapons material. The following publications, which appeared or will be submitted in FY-02, address the issue of nuclear weapons proliferation:

Ougouag, A.M. and H. D. Gougar, November 2001,"Preliminary Assessment of the Ease of Detection of Attempts at Dual Use of a Pebble-Bed Reactor," Transactions of the Winter 2001 Annual Meeting of ANS, Reno, NV, Trans. ANS, Vol.85, pp. 115-117, (Invited).

Ougouag, A.M., W. K. Terry and H. D. Gougar, 2002, "Examination of the Potential for Diversion or Clandestine Dual Use of a Pebble-Bed Reactor to Produce Plutonium," Proceedings of HTR 2002, 1st International Topical Meeting on High Temperature Reactor Technology (HTR), Petten, Netherlands, April 22-24.

Ougouag, A.M., June 2002,"Contribution to the Quantitative Assessment of the Proliferation Resistance of the PBR Concept: Bases for Rational Development of Safeguards," Invited presentation as panelist in Panel on Non-Proliferation Assessment Methodologies at the ANS Spring Annual Meeting, Hollywood, FL, (Invited-no printed paper appeared, but a letter of commendation was received). 
Ougouag, A.M, W. K. Terry, and H. D. Gougar, September 2002,"Proliferation Resistance of the Pebble-Bed Reactor Concept: Examination of the Potential for Diversion or Clandestine Dual Use to Produce Plutonium," to be submitted to Nuclear Engineering and Design in September 2002 (Invited).

Copies of all the published papers cited above are attached to this report (available in the Appendix section of the report). 


\section{CONCLUSION}

This report documents the results of our research in FY-02 on pebble-bed reactor technology under our Laboratory Directed Research and Development (LDRD) project entitled the Modular Pebble-Bed Reactor. The MPBR is an advanced reactor concept that can meet the energy and environmental needs of future generations under DOE's Generation IV initiative. Our work is focused in three areas: neutronics, core design and fuel cycle; reactor safety and thermal hydraulics; and fuel performance.

\section{Fuel Performance}

In the area of fuel performance, our work focused on the development of a chemistry module for the PARticle FUel ModEl (PARFUME) computer code. The purpose of the module was to estimate the chemical forms of fission products formed by fission of U-235 in a fuel kernel containing a mixture of $\mathrm{UO}_{2}$ and $\mathrm{UC}_{2}$ at various $\mathrm{UC}_{2}$ fractions, enrichments, burnup values, and temperatures, and to estimate the partial pressures of $\mathrm{CO}, \mathrm{CO}_{2}$, and noble gases in the kernel-buffer zone of the fuel particles. These results are needed to calculate stresses and fission product transport in the TRISO-coated particle fuel.

Two chemical equilibrium codes, HSC and FACTSAGE, were compared. For a test case the concentrations of substances predicted by the two codes agree in general, but HSC shows a spread of valence distributions while FACTSAGE does not. HSC was chosen for subsequent computations. The 30 dominant fission products were combined into 12 families to facilitate computations.

Equilibria have been calculated for a system with $\mathrm{UO}_{2}, \mathrm{UC}_{2}, \mathrm{Pu}, \mathrm{C}, \mathrm{O}_{2}$, and 12 fission product groups, for which 241 output substances are possible. The equilibria have been computed at 5 values of fuel enrichment, $8 \mathrm{UC}_{2}$ fractions, 7 values of fuel burnup, and 18 temperatures, yielding a database of about 4600 equilibria. The CO concentration predicted by HSC varies slowly with burnup and fuel enrichment, but strongly with temperature. The $\mathrm{CO}$ yield is high with no $\mathrm{UC}_{2}$ present, but drops rapidly to a plateau at $\mathrm{UC}_{2}$ fractions above $10 \%$, then drops to zero as the $\mathrm{UC}_{2}$ fraction approaches $100 \%$. There is also a substantial yield of $\mathrm{CO}_{2}$ in pure $\mathrm{UO}_{2}$ fuel, but not in $\mathrm{UCO}$ fuel. At $\mathrm{T}>1500 \mathrm{~K}$ the ability of lanthanides to bind oxygen decreases, so the yield of $\mathrm{CO}$ could exceed simplified estimates that assume firm binding by lanthanides at all temperatures.

The results were then fitted to polynomials so that fast calculations can be performed inside PARFUME. The results from the model were compared against previous thermodynamic estimates and empirical data on the release of $\mathrm{CO}$ from $\mathrm{UO}_{2}$ coated particle fuel. Pressures of $\mathrm{CO}, \mathrm{CO}_{2}$, and noble gases were 
calculated for a specific fuel design. The $\mathrm{CO}$ and $\mathrm{CO}_{2}$ pressure in $\mathrm{UCO}$ fuel is negligible as expected. However for pure $\mathrm{UO}_{2}$ fuel significant $\mathrm{CO}$ pressures are predicted. The thermodynamic estimates of $\mathrm{CO}$ yield exceed the predictions of $\mathrm{CO}$ release from crushed fuel particles; the difference may be due to incomplete conversion of the excess oxygen to $\mathrm{CO}$ in the particle. However, the thermodynamic model agrees with a thermodynamic estimate of yield assuming the lanthanide fission products form trivalent oxides.

\section{Reactor Safety and Thermal Hydraulics}

Work continued from the previous year in the area of air ingress into pebble-bed reactors. A loss-ofcoolant accident (LOCA) has traditionally been considered a design-basis accident for helium-cooled pebble-bed reactors. Following helium depressurization, it is anticipated that unless countermeasures are taken air will enter the core through the break and then by molecular diffusion and ultimately by natural convection cause oxidation of the in-core graphite structure and graphite pebbles to occur. Thus, without any mitigating features a LOCA will lead to an air ingress event. We have studied such an event with two well-respected light water reactor transient response codes: RELAP5/ATHENA and MELCOR.

To study the degree of core oxidation occurring in a beyond-design-basis air ingress accident, a complete system model using the MELCOR code was developed to describe the behavior of the reactor and surrounding systems. (A modified version of MELCOR developed at INEEL, which includes graphite oxidation capabilities and molecular diffusion of air into helium, was used for these calculations.) Sensitivity studies were performed to determine the response of the system to changes in the air oxidation rate of the pebbles, the functioning of the reactor cavity cooling system (convection vs. natural convection), the availability of air in the surrounding vault, and the location of the break in the cooling system (hot leg vs. cold leg). The accident progression is similar in all cases: following depressurization of the helium, there is a period of stagnation in the reactor during which the air must diffuse into the helium before there is enough driving force in the reactor to begin natural circulation. Once natural circulation begins, a small amount of air enters the reactor and causes oxidation. Changes in the air oxidation rate and the mode of cooling on the outside of the vessel affect the time at which the natural circulation begins and the location of the oxidation in the lower reflector region. However, in all cases examined thus far the oxidation is limited to that in the lower reflector region and fuel is not threatened; fuel temperatures are similar to those expected during a traditional conduction cooldown. Future work is directed at using the oxidation rates of the actual graphite pebbles used in the AVR in Germany; these rates are lower than that used by us previously and thus may shift the oxidation front into the core region, which may be undesirable from a safety standpoint. 


\section{Neutronics, core design and fuel cycle}

In the area of neutronics, core design and fuel cycle, advancements were made in the PEBBED code and PEBBED was applied to address problems of practical interest in pebble-bed reactor technology. The advancements in PEBBED include development of a three-dimensional version, improvements in the matrix formulation of pebble recirculation, enhancements of the depletion solver, and development of heat-transfer models.

The three-dimensional version of PEBBED, PEBBED3, was initiated. In PEBBED3, there are two options for the solution of the neutron diffusion equation in general three-dimensional cylindrical geometry. The first option is a standard finite-difference solution; this option is now fully operational. The second option is a nodal solution; this option is still being implemented.

Many pebble-bed core designs feature a two-zone core that may yield improved fuel economy and heat transfer over randomly loaded single-zone cores like the HTR Modul. For example, the South African PBMR consists of a graphite central zone and a fueled outer zone. The relative sizes of the zones are determined by the relative flow rates of pebbles through the inner and outer loading tubes; there is no physical barrier between the zones. In burnup-dependent two-zone cores, pebbles are loaded fresh into one zone and, at some point in their burnup history, transferred to the other zone. Previously, such cores were modeled in PEBBED by manually generating the recirculation matrix "off-line" and reading it into the code. The matrix algorithm was upgraded in PEBBED3 to generate the recirculation matrices internally and automatically for multiple pebble types tracing independent paths through two-zone cores. Complex cores of this type can be modeled and optimized through the manipulation of a few key parameters in the input deck.

In PEBBED2, only one fissile nuclide could be specified in the fuel. The accuracy obtainable in modeling pebble-bed cores with high burnup or multiple fuel types was improved by enabling the code to compute fission yields for up to three fissile isotopes. Most core designs contain uranium-235 as the dominant fuel type, but in high-burnup cores a significant buildup of $\mathrm{Pu}-239$ can occur. Cores containing fertile thorium will build in a large amount of fissile U-233. The fission-product yields of these fuel isotopes differ; thus, different fuel mixes will produce different nuclide distributions and discharge isotopics. PEBBED3 is able to compute and track depletion and buildup in multi-fuel cores.

A one-dimensional heat transfer model implemented in PEBBED2 has been improved for PEBBED3. The fuel temperature module was improved by adding a graphite thermal conductivity correlation 
dependent on temperature and neutron fluence. The correlation developed at Oak Ridge National Laboratory, accurately accounts for the thermal conductivity in a pebble given its irradiation history. Coupled with the zone-dependent axial coolant temperature calculation, the correlation gives good approximations of pebble fuel temperature throughout the core and over the history of a given pebble type.

In addition, post-accident fuel temperatures following a result of a loss of coolant flow were estimated using a one-dimensional (radial) transient heat conduction/radiation module implemented in PEBBED3. The temperatures were shown to depend strongly on the steady-state core power density. This feature allows a core optimization study to include the post-accident peak temperature as one of the parameters in an overall objective function.

The subcontract work with the Georgia Institute of Technology continued. The codes originally planned for use in cross-section processing, COMBINE and TORT, had been shown in FY-01 to be unsuitable; in FY-02 the codes WIMS and EVENT were selected, tested, and shown to be appropriate.

Since PEBBED is being developed as a practical tool with which to answer questions about the performance of real PBRs, it is appropriate to test its capabilities at each stage in its development by applying it to address practical issues. During FY-02, PEBBED was used to investigate questions on the deployment of PBRs in remote locations and on the susceptibility of PBRs to be used for nuclear weapons proliferation. Our work on nonproliferation of nuclear weapons has shown that the PBR is a poor choice for overt or covert production of nuclear weapons material. 


\section{REFERENCES}

Alexander, C.A., et al., 1990, "Rare earth and actinide release characteristics from solid and molten fuels," Fission Product Transport Processes in Reactor Accidents, Hemisphere Publishing, New York, pp. 127-135.

Barin, I., O. Knacke, and O. Kubaschewski, 1977, Thermochemical Properties of Inorganic Substances, Springer-Verlag, Berlin.

Barin, I., 1989, Thermochemical Data of Pure Substances, VCH Verlags Gesellschaft, Weinheim.

Barin, I., 1993, Thermochemical Data of Pure Substances, Parts I and II, VCH Verlags Gesellschaft, Weinheim.

Bennett, R.C. et al., "A system of ${ }^{99 \mathrm{~m}} \mathrm{Tc}$ production based on distributed electron accelerators and thermal separation," Nuclear Technology, Vol. 126, pp.102-121.

Bews, I. M., et al., 2001, " The Order, Arrhenius Parameters, and Mechanism of the Reaction Between Gaseous Oxygen and Solid Carbon," Combustion and Flame, Vol. 124, pp. 231-245.

Brisdon, A.K., et al., 1990, "Matrix isolation-infrared spectroscopic and mass spectrometric studies of high temperature simulant fission products," Fission Product Transport Processes in Reactor Accidents, Hemisphere Publishing, New York, pp. 137-151.

Cordfunke, E.H.P, and R.J.M. Konings, 1990, Thermochemical Data for Reactor Materials and Fission Products, North-Holland, Amsterdam.

Czechowicz, D.G., February 17, 1992, Influence of UCO composition on CO generation for NP-MHTGR fuel-consequence of high CO pressure on fuel performance, CEGA-M-92-0580.

"FactSage 5.0 Thermochemical Software and Databases," April 2001, www.factsage.com.

Frewer, H., and W. Keller, 1985, "The Modular High-Temperature Reactor," Nuclear Science and Engineering, Vol. 90, pp.411- 426.

Fukuda, K., K. Hayashi, and K. Shiba, 1990, "Fuel behavior and fission product release under HTGR accident conditions," Fission Product Transport Processes in Reactor Accidents, Hemisphere Publishing, New York, pp. 197-204.

Garisto, F., F. C. Iglesias, and C. E. L. Hunt, 1990, "A thermodynamic/mass-transport model for the release of ruthenium from irradiated fuel," Fission Product Transport Processes in Reactor Accidents, Hemisphere Publishing, New York, pp. 257-265.

Heames, T.J., et al., 1992, "VICTORIA: a mechanistic model of radionuclide behavior in the reactor coolant system under severe accident conditions," NUREG/CR-5545, SAND90-0756” Rev. 1, R3, R4. 
Hobbins, R.R., et al., 1990, "Fission product release as a function of chemistry and fuel morphology," Fission Product Transport Processes in Reactor Accidents, J. T. Rogers, Editor, Hemisphere Publishing, New York, pp. 215-224.

Homan, F.J., et al., 1977, "Stoichiometric effects on performance of high-temperature gas-cooled reactor fuels from the U-C-O system," Nuclear Technology, Vol. 35, pp. 428-441.

Horsley, G. W. et al., 1976, "Influence of irradiation temperature, burnup, and fuel composition on gas pressure (Xe, $\mathrm{Kr}, \mathrm{CO}, \mathrm{CO} 2)$ in coated particle fuels," Journal of the American Ceramic Society, Vol. 59, No. 1-2, 1-4. (See algorithms at the bottom of their Table III.)

Hunt, C.E.L., F. C. Iglesias, and D. S. Cox, 1990, "Measured released kinetics of iodine and cesium from $\mathrm{UO}_{2}$ at high temperatures under reactor accident conditions," Fission Product Transport Processes in Reactor Accidents, Hemisphere Publishing, New York, pp. 163-173.

Iglesias, F.C. et al., 1990, "Ruthenium release kinetics from uranium oxides," Fission Product Transport Processes in Reactor Accidents, Hemisphere Publishing, New York, pp. 187-196.

Kleykamp, H., 1993, "The solubility of selected fission products in $\mathrm{UO}_{2}$ and $(\mathrm{U}, \mathrm{Pu}) \mathrm{O}_{2}$," Journal of Nuclear Materials, Vol. 206, pp.82-86.

Knacke, O., O. Kubaschewski, and K. Hesselman, 1991, Thermochemical Properties of Inorganic Substances, $2^{\text {nd }}$ Edition, Springer-Verlag, Berlin.

Kovacs, W.J., K. Bongartz, and D.T.Goodin, 1985, "High-temperature gas-cooled reactor fuel pressure vessel performance models," Nuclear Technology, Vol. 68, pp.344.

Kosolapovoi, T.C., 1986, Svoistva, polysenie i primenie tugoplavkih soedinenij, Moskva, pp.928.

Lake, J.A., R.G. Bennett, and J.F. Kotek, January 2002, "Next Generation Nuclear Power," Scientific American, pp.73-81.

Marshall, T. D. et al., 2002, Air Chemical Reactivity Measurements of the Carbon Fiber Composite NB31, INEEL/EXT-02-00745, Idaho National Engineering and Environmental Laboratory.

Martin, D.G., 2001, "Physical and mechanical properties of the constituents of coated fuel particles and the effect of irradiation," HTR-F WP3 Meeting, Lyon, France, October 18, 2001.

Martin, D.G., 2002, "Considerations pertaining to the achievement of high burn-ups in HTR fuel," Nuclear Engineering and Design 213, pp. 241-258.

McCardell, R.K. et al., September 1992, "NP-MHTGR Fuel Development Program Plan," EGG-NPR- 8971, Rev. C, pp. A-1 to A-14.

Moormann, R. et al., September 1999, "Oxidation of Carbon Based Materials for Innovative Energy System (HTR, Fusion Reactor): Status and Further Needs," OECD Proceeding-Survey on Basic Studies in the Field of High Temperature Engineering, Paris, France, 27-29 September 1999.

Nicholls, D., September 2001, “The Modular Pebble-Bed Reactor,” Nuclear News, pp. 35-40.

Proksch, E., A. Strigl, and H. Nabielek, 1982, "Production of carbon monoxide during burn-up of $\mathrm{UO}_{2}$ kerneled HT fuel particles," Journal of Nuclear Materials, Vol. 107, pp.280-285. 
Rard, J.A., et al., 1999, Chemical Thermodynamics of Technetium, Nuclear Energy Agency, Elsevier Publishing Company, Amsterdam.

Roine, A., 1997, “Outokumpu HSC Chemistry for Windows, Chemical Reaction and Equilibrium Software with Extensive Thermochemical Database," User's Guide Version 3.0, Outokumpu Research, Oy, Pori, Finland.

Savage, M.G., 1984, A One-Dimensional Modeling of Radiant Heat Removal During Pressurized Heatup Transients in Modular Pebble-Bed and Prismatic High Temperature Gas-Cooled Reactors, ORNL- TM9215, Engineering \& Mathematics Division, Oak Ridge National Laboratory.

Sayers, J.B., et al., 1973, "Coated particle fuels for the low enriched fuel cycle in HTR," Proceedings of British Nuclear Energy Society Conference on Nuclear Fuel Performance, London, England, 1973, Paper No. 32.

Strigl, A., and E. Proksch, 1977, "Restoration Of Carbon Monoxide Equilibrium In Porous Oxide HighTemperature Reactor Fuel Particles," Nuclear Technology, Vol. 35, pp.386-391.

Sutton, T. M., 1989, "NODEX: A High Order NEM-Based Multigroup Nodal Code," Proceedings of the ANS Topical Meeting on Advances in Nuclear Engineering Computation and Radiation Shielding, Santa Fe, New Mexico, April 9-13, Vol. 1, pp. 38:1- 38:11.

Teague, H.J., and D. F. Torgerson, 1990, “A generic overview of severe accident phenomena,” Fission Product Transport Processes in Reactor Accidents, Hemisphere Publishing, New York, pp. 3-26.

Terry, W. K, (editor), 2001, Modular Pebble-Bed Reactor Project, Laboratory-Directed Research and Development Program FY 2001 Annual Report, INEEL/EXT-2001-1623, Idaho National Engineering and Environmental Laboratory, MIT, December 2001.

Vondy, D.R., 1981, PEBBLE: A Two-Dimensional Steady-State Pebble-Bed Reactor Thermal Hydraulics Code, ORNL-5696, Union Carbide Corporation, Nuclear Division, Oak Ridge, TN.

Wagman, D.D., et al., 1982, "The NBS tables of chemical thermodyamic properties, Selected values for inorganic and $\mathrm{C}_{1}$ and $\mathrm{C}_{2}$ organic substances in SI units," Journal of Physical and Chemical Reference Data, Vol. 11, Supplement No. 2.

Wagner-Löffler, M., 1977, “Amoeba behavior of $\mathrm{UO}_{2}$ coated particle fuel,” Nuclear Technology, Vol. 35, pp.392-402.

Wagner-Löffler, M., 1973, “The significance of gas-pressure build-up in coated particles,” Proceedings of British Nuclear Energy Society Conference on Nuclear Fuel Performance, London, England, 1973, Paper No. 36.

Weaver, K., 2001 (unpublished), "Calculations of fission product yield and plutonium yield per pebble in $\mathrm{UO}_{2}$ pebble-bed fuel using MOCUP”.

Wichner, R. P. and S.J., Ball, 1999, Potential Damage to Gas-Cooled Graphite Reactors Due to Severe Accidents, ORNL/TM-13661, Oak Ridge National Laboratory, Appendix A. 


\section{APPENDIX A. ANTICIPATED BEHAVIORS OF VARIOUS FUELS AND FISSION PRODUCTS}

Although the situation in UCO TRISO fuel would be different from LWR fuels, the $\mathrm{UO}_{2}$ fuel results can provide guidance on the general trends, such as which compounds would be dominant at a given temperature. The forms of fission products depend strongly on the atmosphere surrounding the fuel. In a steam atmosphere, elements like Cs, $\mathrm{Mo}, \mathrm{Sb}, \mathrm{Sn}$, and $\mathrm{Cd}$ could be oxidized at high temperatures, but in an $\mathrm{H}_{2}$ atmosphere, they would tend to remain in metallic form. (Hobbins 1990) For intact TRISO particles, the fuel would probably not be exposed to air or steam, and oxidation would be limited to the oxygen liberated from $\mathrm{UO}_{2}$.

Table A-1 shows the Gibbs energies of formation of various oxides ( $\mathrm{kJ}$ per g-atom of oxygen) computed with the HSC code. These values were illustrated in Figure 2. HSC uses mainly data from Barin (1989 and 1993), which is generally consistent with the National Bureau of Standards data (Wagman et al. 1982). The properties of various fission products will be discussed below.

\section{Ag}

$\mathrm{Ag}$ is a noble metal that cannot bind significant amounts of oxygen. Ag diffuses readily and its release is a significant concern for accident scenarios.

\section{Ba}

Barium tends to form carbides before oxides. (Homan 1977) Its strong affinity for oxygen (Figures 2 and 3) will inhibit $\mathrm{CO}$ formation. The solubility of $\mathrm{BaO}$ in $\mathrm{UO}_{2}$ at $2000 \mathrm{~K}$ is only $0.58 \mathrm{~mol} \%$. (Kleykamp 1993)

$\mathrm{Br}$

Bromine is a volatile halide that does not trap appreciable oxygen. Its high mobility is of concern, and it could be released after cracking of the TRISO coatings.

\section{Cd}

Cadmium tends to form a metallic phase, and it cannot bind significant oxygen.

Cs

Cesium oxide has a weak Gibbs energy of formation. Cesium is a highly volatile metal, which can form many compounds with other fission products, such as $\mathrm{Cs}_{2} \mathrm{Te}_{2} \mathrm{O}_{5}, \mathrm{Cs}_{2} \mathrm{TeO}_{3}, \mathrm{CsTeO}_{2}$, chalcogenides $\left(\mathrm{Cs}_{1-\mathrm{x}} \mathrm{Rb}_{\mathrm{x}}\right)_{2} \mathrm{Si}_{1-\mathrm{y}} \mathrm{Te}_{\mathrm{y}}, \mathrm{CsI}$, 
$\mathrm{Cs}_{2} \mathrm{ZrO}_{3}, \mathrm{Cs}_{4} \mathrm{U}_{2} \mathrm{O}_{7}, \mathrm{Cs}_{2} \mathrm{MoO}_{4}$, chromates, silicates, and borates. Cesium release from $\mathrm{UO}_{2}$ fuel in air began about $973 \mathrm{~K}$ and reached nearly $100 \%$ at $1373 \mathrm{~K}$. (Hunt 1990) In the presence of steam, CsOH would probably be the dominant cesium species in an LWR containment. (Teague 1990) Cs is highly mobile. Japanese tests of release from a single TRISO coated fuel particle showed large fractional releases of Cs and Eu at temperatures over 2173 K. (Fukuda 1990) Cesium has very low solubility in $\mathrm{UO}_{2}$. (Kleykamp 1993)

\section{I}

Iodine is a volatile halide that does not trap appreciable oxygen. Its high mobility is of concern, and it could be released after cracking of the TRISO coatings. Iodine is highly reactive and reacts with $\mathrm{Cs}, \mathrm{Ag}, \mathrm{H}_{2} \mathrm{O}$, and organic substances (paints, lubricants, insulation, gaskets, etc.) (Teague 1990) Iodine release from $\mathrm{UO}_{2}$ fuel in air begins at $773 \mathrm{~K}$, increasing to $100 \%$ at $1373 \mathrm{~K}$. (Hunt 1990)

\section{Lanthanides (La, Ce, Pr, Nd, Pm, Sm, Eu, Gd...) and Y}

Free oxygen atoms bind strongly to $\mathrm{Y}$ and the Lanthanide fission products, which have large negative Gibbs energies of oxide formation. For Europium the oxygen potential is more like that of $\mathrm{Ba}$ and $\mathrm{Zr}$ than those of the other lanthanides (Figures 2 and 3). Data on Pm are lacking, and it is assumed that Pm behaves similarly to the other lanthanides. At $2500 \mathrm{~K}$ the volatilities of the monoxides are much greater than those of the metals.

(Alexander 1990) Yttrium and the lanthanides have high solubilities in $\mathrm{UO}_{2}$. (Kleykamp 1993)

\section{Mo}

Molybdenum has a higher affinity for oxygen than ruthenium and is more volatile than ruthenium under oxidizing conditions. For example, in a pure steam atmosphere Mo would oxidize to solid $\mathrm{MoO}_{2}$, leaving Ru behind.

(Garisto 1990) Irradiated $\mathrm{UO}_{2}$ fuel specimens showed a mixture of alloy phase Mo and molybdenum oxides dissolved in the fuel. (Potter 1990) At T $>1000 \mathrm{~K}$ the Gibbs energies of molybdenum oxides become weaker than that of $\mathrm{CO}$, so in the presence of carbides the molybdenum oxides would tend to form only at lower temperatures. Molybdenum and its oxides have very low solubility in $\mathrm{UO}_{2}$. (Kleykamp 1993)

\section{$\mathrm{Nb}$}

With a strong Gibbs energy of oxide formation $\mathrm{Nb}$ can bind appreciable quantities of oxygen as $\mathrm{Nb}_{2} \mathrm{O}_{5}$ and inhibit $\mathrm{CO}$ formation, except at $\mathrm{T}>1700 \mathrm{~K}$ (Figure 2).

\section{Pd}

Pd is a noble metal that cannot bind significant amounts of oxygen. 


\section{$\mathbf{R b}$}

Rubidium is a volatile alkali metal, with a weak Gibbs energy of oxide formation. According to Homan (1977), "Cesium and rubidium are not present as oxides. The oxygen potential values of the $\mathrm{UO}_{2}-\mathrm{UC}_{2}$ system are much lower than those necessary for the stability of the uranates and molybdates of cesium and rubidium."

\section{$\mathbf{R h}$}

Rhodium has a very weak Gibbs energy of oxide formation, so it will not bind significant amounts of oxygen.

\section{Ru}

Ruthenium metal has a high boiling point and is nonvolatile under reducing conditions. Under oxidizing conditions ruthenium can form volatile oxides, but the corresponding Gibbs energies are too weak for significant oxygen to be bound by $\mathrm{Ru}$ fission products in competition with other elements considered here. Studies of Ru release from $\mathrm{UO}_{2}$ in air showed a delay time during which oxidation occurred, followed by gradual release of the ruthenium. The release rate grew rapidly with temperature from $0.06 \% / \mathrm{min}$ at $1113 \mathrm{~K}$ to $6.5 \% / \mathrm{min}$ at $1373 \mathrm{~K}$. (Iglesias 1990) Under most accident circumstances Ru would remain in metallic form, with little release from the fuel, because of its low volatility. (Hobbins 1990) Ruthenium has very low solubility in $\mathrm{UO}_{2}$. (Kleykamp 1993)

\section{Sb}

Antimony has a low Gibbs energy of oxide formation, so it cannot bind significant amounts of oxygen in the presence of carbon, except at very low temperatures $(\mathrm{T}<700 \mathrm{~K})$.

Se

Selenium is a volatile fission product, which cannot bind significant amounts of oxygen in the presence of carbon.

\section{Sn}

Tin could bind some oxygen at the lower temperatures, but its Gibbs energy of oxide formation at $\mathrm{T}>900 \mathrm{~K}$ is less than that of carbon, so it would not inhibit $\mathrm{CO}$ formation significantly at high temperatures.

Sr

Strontium tends to form carbides before oxides. (Homan 1977) The affinity of Sr for oxygen is stronger than the affinity of carbon for oxygen, except at very high temperatures (Figure 3). Thus, Sr will bind with free oxygen atoms and inhibit $\mathrm{CO}$ formation. SrO has a solubility of about $12 \mathrm{~mol} \%$ in $\mathrm{UO}_{2}$ at $1773 \mathrm{~K}$. (Kleykamp 1993) 


\section{Tc}

The main oxide of technetium is $\mathrm{Tc}_{2} \mathrm{O}_{7}$. This oxide melts at $393 \mathrm{~K}$ and boils near $600 \mathrm{~K}$, so it is quite volatile. (Rard 1999) The vapor pressure difference between $\mathrm{MoO}_{3}$ and $\mathrm{Tc}_{2} \mathrm{O}_{7}$ is used in a scheme for production of Tc-99m in electron accelerators by photonuclear reactions in Mo-100. After irradiation, a mixture of $\mathrm{MoO}_{3}$ and $\mathrm{Tc}_{2} \mathrm{O}_{7}$ is vaporized in a boat at $1123 \mathrm{~K}$. Then the small fraction of vaporized $\mathrm{MoO}_{3}$ is condensed in a region where the temperature is $863-1063 \mathrm{~K}$, and the completely vaporized $\mathrm{TC}_{2} \mathrm{O}_{7}$ flows on to condense in a lower temperature region (298-653 K). (Bennett 1999)

\section{Te}

Tellurium is a volatile fission product. It can form various oxides, but its affinity for oxygen is less than that of carbon, so $\mathrm{CO}$ formation is more likely than $\mathrm{TeO}_{2}$ formation at temperatures above $300 \mathrm{~K}$. Te can also form compounds with various other elements, including $\mathrm{Cs}\left(\mathrm{Cs}_{2} \mathrm{Te}_{2} \mathrm{O}_{5}, \mathrm{Cs}_{2} \mathrm{TeO}_{3}, \mathrm{CsTeO}_{2}\right), \mathrm{Sn}\left(\mathrm{Sn}_{2} \mathrm{Te}_{2}, \mathrm{SnTe}\right)$, Indium $\left(\mathrm{In}_{2} \mathrm{Te}_{3}, \mathrm{InTe}, \mathrm{In}_{2} \mathrm{Te}\right)$, and chalcogenides $\left(\mathrm{Cs}_{1-\mathrm{x}} \mathrm{Rb}_{\mathrm{x}}\right)_{2} \mathrm{Si}_{1-\mathrm{y}} \mathrm{Te}_{\mathrm{y}}$ (Potter 1990; Brisdon 1990) Because of its weak Gibbs energy of oxide formation, Te will not bind significant amounts of oxygen in the fuel matrix. Te might contribute to oxygen trapping by Cs. The isotope Te-132 decays ( $3.25 \mathrm{~d})$ into I-132, so its chemical behavior changes after decay.

\section{Xe and Kr}

These noble gases have negligible affinity for oxygen. Their accumulation and pressure must be calculated to determine stresses in fuel particles.

\section{$\mathrm{U}$ and $\mathrm{Pu}$}

The free oxygen released by fission exceeds the oxygen needs of the lanthanides, so the lanthanides would not reduce the $\mathrm{UO}_{2}$ appreciably. $\mathrm{UC}_{2}$ will gradually be oxidized by the excess oxygen via the reaction:

$\mathrm{UC}_{2}+\mathrm{O}_{2} \rightarrow \mathrm{UO}_{2}+2 \mathrm{C}$

Thus, $\mathrm{UC}_{2}$ can bind with free oxygen to help inhibit $\mathrm{CO}$ formation. Plutonium bred by neutron absorption in U-238 can also interact with oxygen and carbon to form $\mathrm{PuC}, \mathrm{PuO}, \mathrm{PuO}_{2}, \mathrm{Pu}_{2} \mathrm{O}_{3}$, and other compounds. The Gibbs energies of formation of plutonium oxides are similar to those of uranium oxides. Pu is a sink for free oxygen, but fission of plutonium oxides releases more free oxygen. 
$\mathbf{Z r}$

The dominant oxide of zirconium is $\mathrm{ZrO}_{2}$. The oxygen potential of zirconium is stronger than that of carbon, except at very high temperatures (Figure 3), so it will inhibit $\mathrm{CO}$ formation. The solubility of $\mathrm{ZrO}_{2}$ in $\mathrm{UO}_{2}$ increases from $0.4 \mathrm{~mol} \%(1473 \mathrm{~K})$ to $15 \mathrm{~mol} \%$ (1773 K) and $51 \mathrm{~mol} \%$ (1973 K). (Kleykamp 1993) 


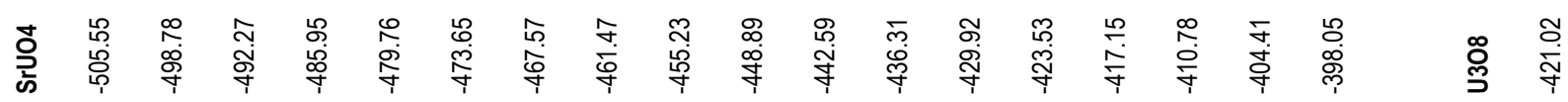

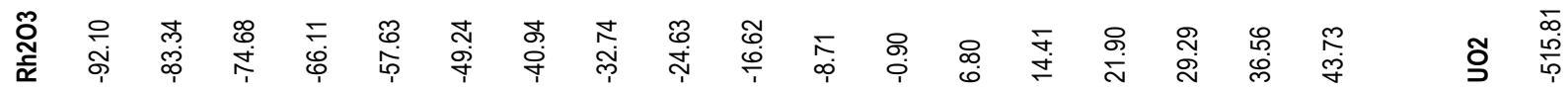

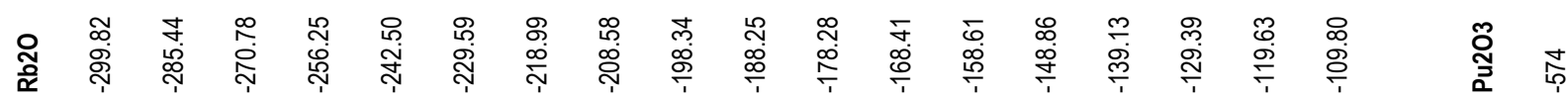

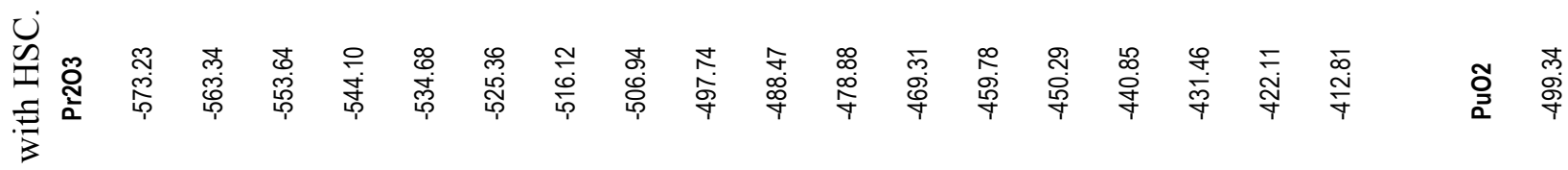

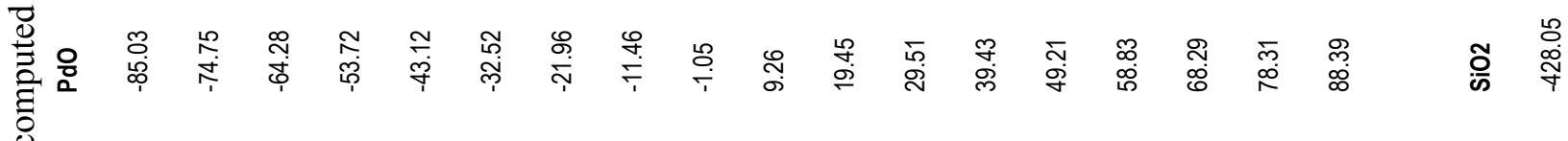

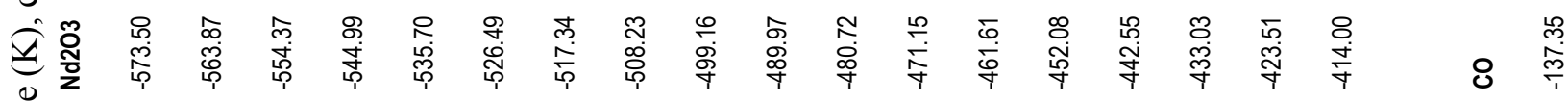

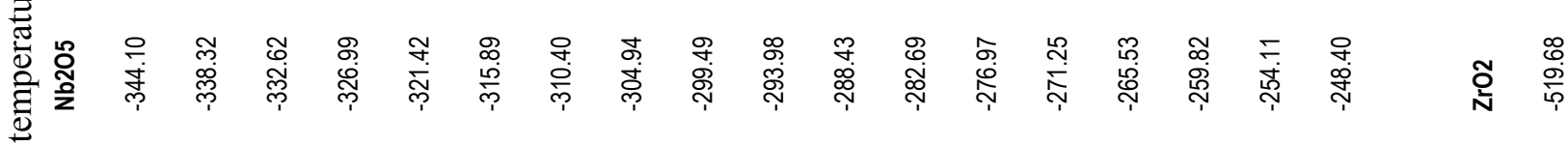

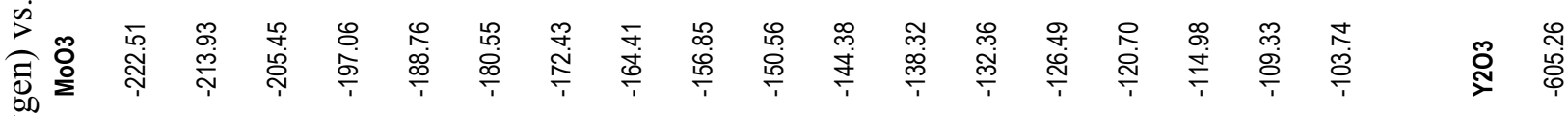

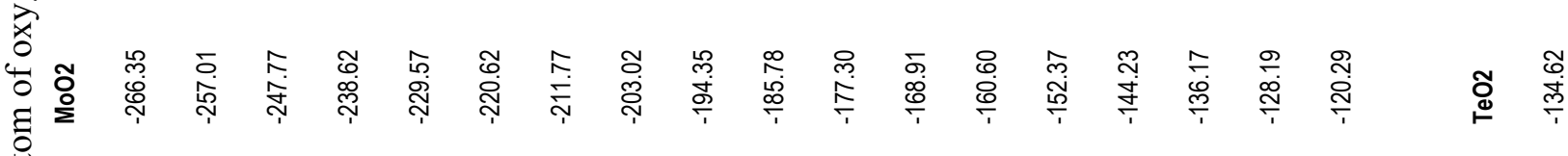

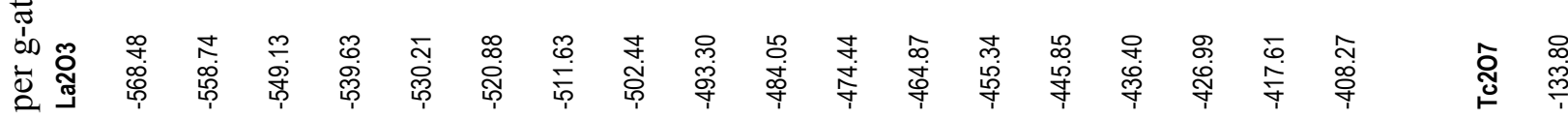

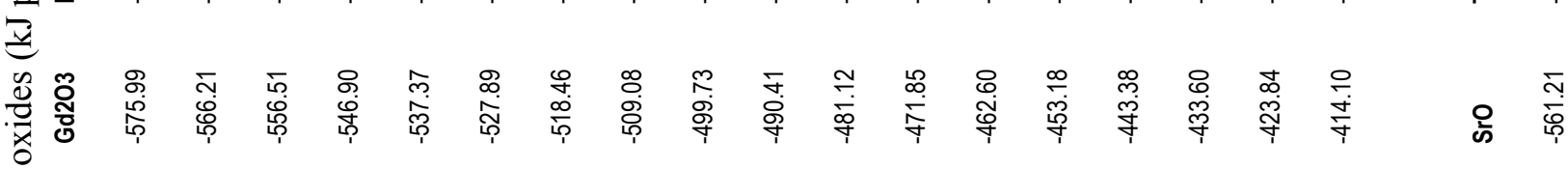

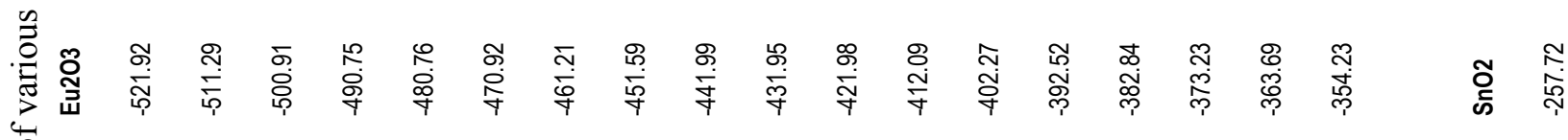

节

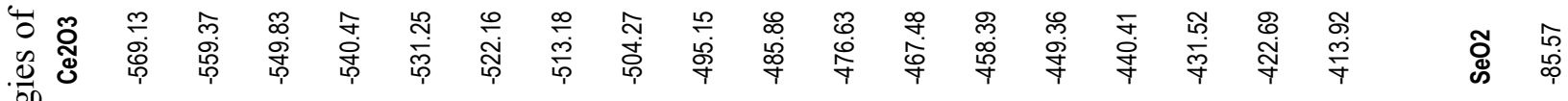

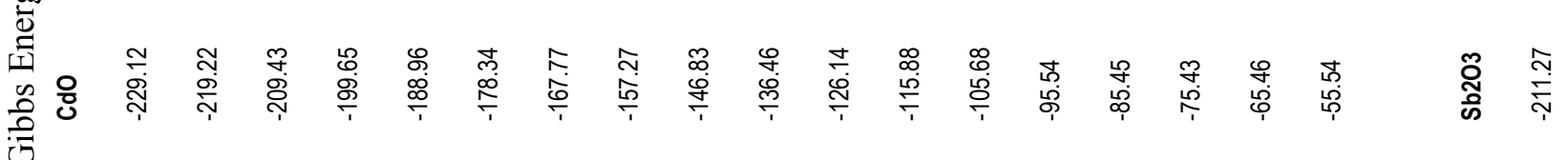

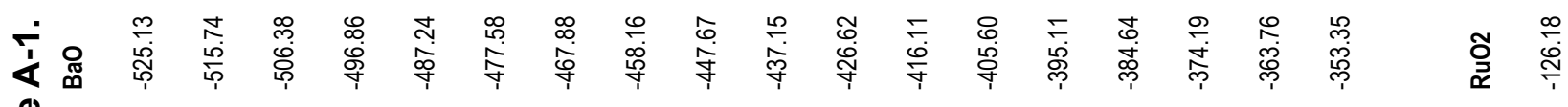

䯩 


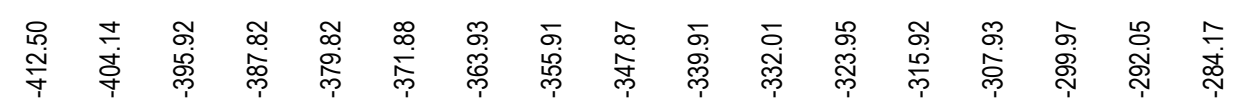

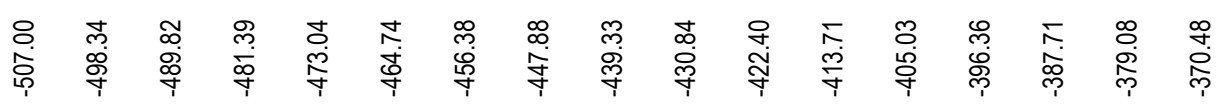

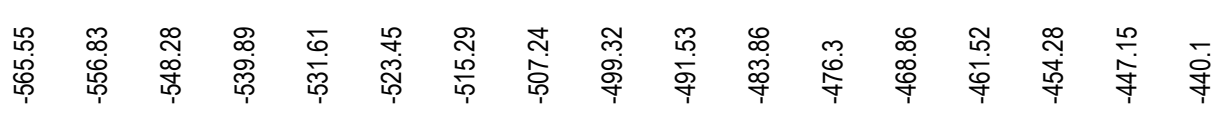

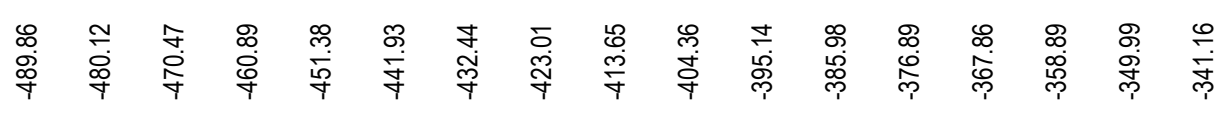

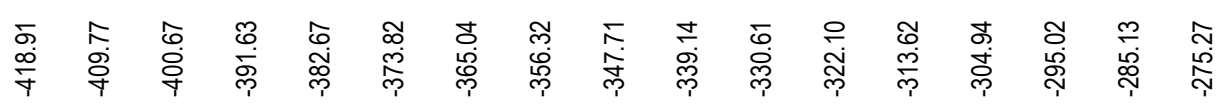

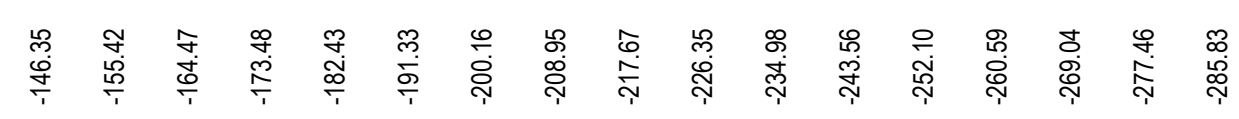

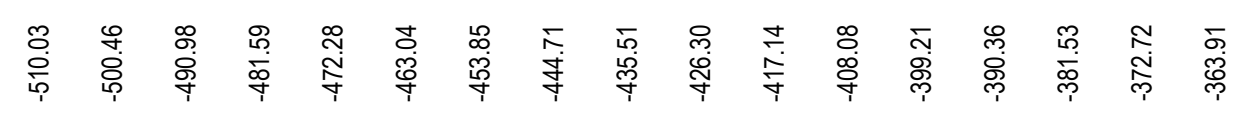

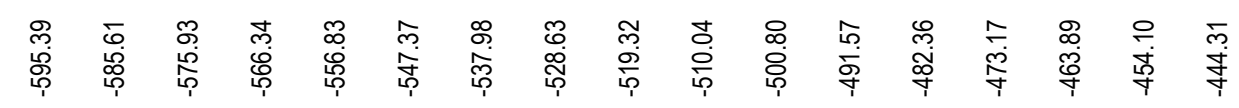

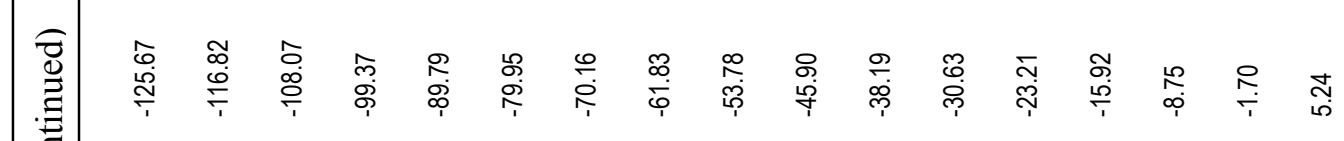

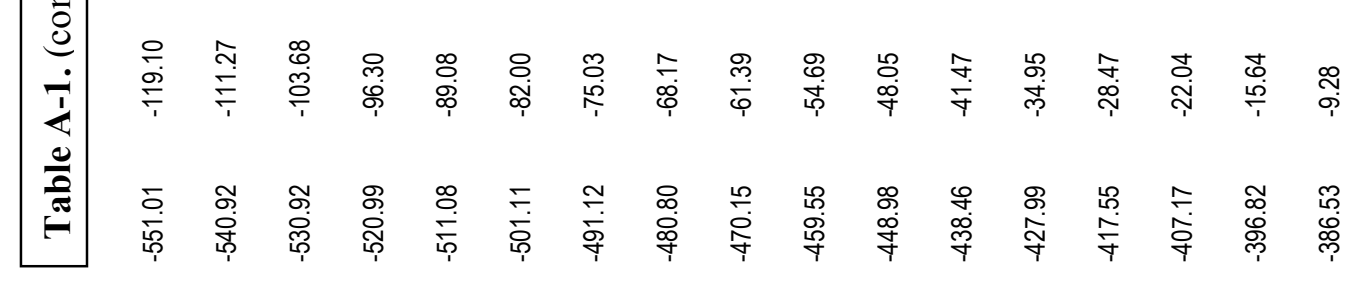

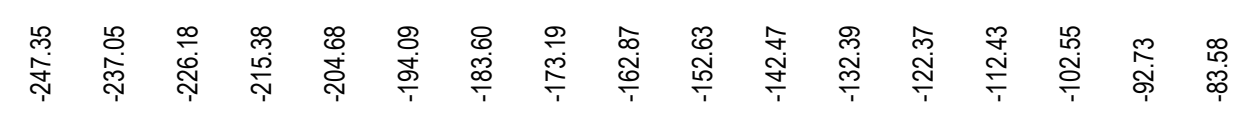

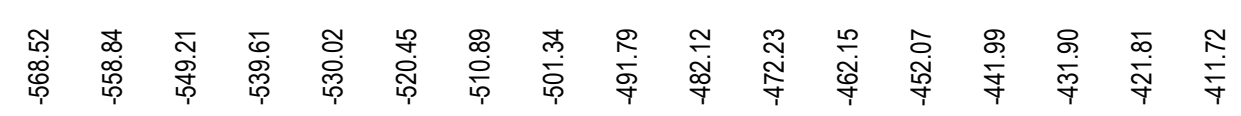

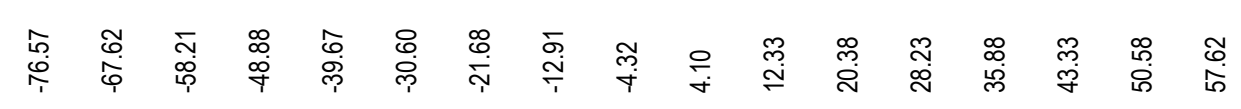

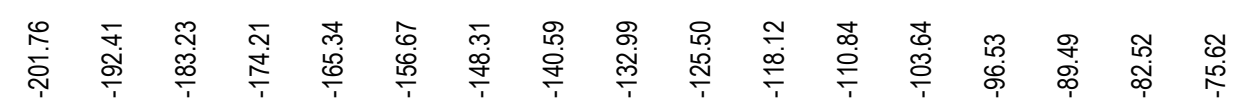

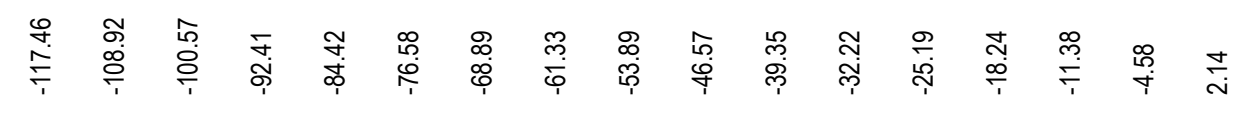

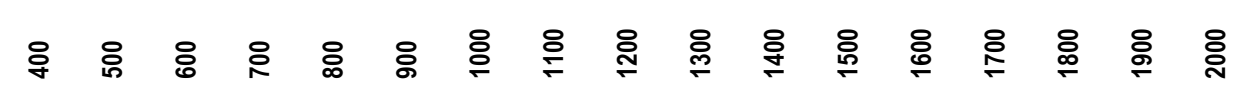




\section{APPENDIX B. USE OF HSC AND FACTSAGE CODES}

For a comparison of the HSC and FACTSAGE codes the 30 main fission products (Table 2) were grouped into 10 groups (Table B1). Only the dominant first 6 groups were used, in order to reduce the number of chemical reaction products that must be considered. The other four groups (the Pd, Te, I, and Cd groups), which comprise only $4-7 \%$ of the fission products and which do not have strong oxygen affinities, were ignored. Later the accuracy of the 6-group approximation was assessed by comparing the $\mathrm{CO}$ yield predicted by 6-group model with that predicted by a 12-group model. Over the temperature range $500-2000 \mathrm{~K}$ the two models agreed within $2 \%$.)

The fission product yield calculations list mol of fission products per fuel pebble. (Weaver 2001) Each fuel pebble initially contains $9 \mathrm{~g}$ (uranium), so there are $9 / 237.7=0.0379 \mathrm{~mol}$ of uranium per pebble. Since there are two fission products per fission, the atomic burnup is equal to half the number of mols of fission products generated per pebble divided by $0.0379 \mathrm{~mol}(\mathrm{U})$. Table B2 shows the molar quantities of the 11 input constituents $\left(\mathrm{UO}_{2}, \mathrm{UC}_{2}, \mathrm{Pu}, \mathrm{O}_{2}, \mathrm{C}, \mathrm{Zr}, \mathrm{Xe}, \mathrm{Mo}, \mathrm{La}, \mathrm{Cs}, \mathrm{Sr}\right)$ per pebble vs. burnup for a case with $\mathrm{c}=30 \%$, e $=10 \%$.

For these 11 input constituents the HSC-4.1 Code (Roine 1997) lists 138 possible reaction products to be considered, and FACTSAGE-5.1 Code (FactSage 2001) lists 148. These lists of product substances are compared in Table B3. Since the FACTSAGE code did not have data for $\mathrm{UC}_{2}$, the data for $\mathrm{U}_{10} \mathrm{C}_{19}$ were used in early code runs. HSC groups solids and liquids together (such as for $\mathrm{MoO}_{3}$ ), but FACTSAGE lists them separately. The equilibrium results show that most of the species in Table B3 have negligibly small concentrations, and only about $20-30$ of them have concentrations exceeding $10^{-6}$ mol per fuel pebble.

According to early code results, the amount of CO predicted by FACTSAGE was three orders of magnitude lower that that predicted by HSC. In order to understand the reason for such inconsistencies, the internal code database predictions of the Gibbs energies $\mathrm{G}$ at $1300 \mathrm{~K}$ were compared for the dominant substances. (The Gibbs energies of formation of the substances $\Delta \mathrm{G}_{\mathrm{f}}{ }^{\mathrm{j}}$ were not available directly from the FACTSAGE code.) For some substances the values differed by significant amounts, as shown in Table B4. The original references of the two codes' data sets were compared, and the better data set for each compound was used in both codes. Data for $\mathrm{SrUO}_{4}$ were added to HSC; and the data from HSC were added to FACTSAGE for $\mathrm{LaC}_{2}, \mathrm{Mo}_{2} \mathrm{C}, \mathrm{MoC}, \mathrm{Pu}_{2} \mathrm{O}_{3}, \mathrm{SrC}_{2}$, and $\mathrm{UC}_{2}$. 
After these improvements were made, the two codes were compared again, with the result shown in Table $\mathrm{B} 5$ for a case with $\mathrm{b}=113 \mathrm{MWd} / \mathrm{kg}, \mathrm{c}=30 \%, \mathrm{e}=10 \%$, and $\mathrm{T}=1300 \mathrm{~K}$, omitting substances with low concentrations (except for $\mathrm{CO}$ ). The $\mathrm{CO}$ concentrations differed by only $1.5 \%$. The two codes agree on most concentrations, but FACTSAGE predicts no elemental $\mathrm{Cs}$, no $\mathrm{LaC}_{2}$, only one form of $\mathrm{Mo}$, and only one carbide of $\mathrm{U}$. HSC shows a spread of valence distributions (such as $\mathrm{MoC}, \mathrm{Mo}_{2} \mathrm{C}, \mathrm{Mo}_{2} \mathrm{C}_{3}$; and $\mathrm{UC}$, $\mathrm{UC}_{2}, \mathrm{U}_{2} \mathrm{C}_{3}$ ) while FACTSAGE tends to show a concentration on only one compound (only $\mathrm{Mo}_{2} \mathrm{C}$ and $\mathrm{U}_{2} \mathrm{C}_{3}$ ). FACTSAGE predicts all $\mathrm{MoC}$ at low temperatures, switching abruptly to all $\mathrm{Mo}_{2} \mathrm{C}$ at about 900 $\mathrm{K}$, while HSC predicts a gradually varying mix of carbides. It appears that FACTSAGE may converge on an equilibrium dominated by one species in some cases. HSC has a manual, but FACTSAGE does not. In view of the database accuracy, valence distributions, and availability of a manual, HSC was chosen for subsequent calculations.

The oxides of strontium, zirconium, yttrium and the lanthanides have high solubilities in $\mathrm{UO}_{2}$, but oxides of barium, molybdenum, and most other fission products have poor solubility, and tend to remain segregated. (Kleykamp 1993) These phase differences need to be taken into account in running the chemical equilibrium codes. HSC treats species as dissolved, unless they are deliberately placed in separate phases. Most of the code runs were done in the default condition (dissolved). The code was also run with all the oxides and pure elements input both as dissolved species and in separate phases (a total of 104 phases) to let the code determine which phases (segregated or dissolved) were preferred in the equilibrium. The results were identical with those of the default case.

According to J. Christian (personal communication 2002) the following precautions should be taken when using HSC:

1. When doing solid-state reaction/equilibrium calculations, HSC puts all condensed species into a single phase and, therefore, treats the system as an ideal (Raoult's law) solution, calculating 'concentrations' (activities) in the solution. If separate (pure) phases are expected, one must put the individual species into separate phases in the input table. This will give a different, and correct, result.

2. When working with condensed-gas phase combinations, the equilibrium gas species compositions add to $1 \mathrm{~atm}$. Therefore, sum the number of kilomoles of them all, divide the result into 1, and multiply all the gas species amounts by this number to get each partial pressure in atm. If an excess of gas phase is present, the results will be approximately independent of how much you start with. If it is deficient 
relative to the amount consumed by the condensed species that you start with, there will be a dependency.

3. When not certain about the accuracy of the database values for the species of interest, they should be checked by going to original literature, traced through the references given in the database. Don't rely on the source being a standard thermodynamic data compilation, e.g., Kubaschewski et al. Some errors get propagated from compilation to compilation. For example, in one instance, the enthalpy of formation had the sign reversed in an original compilation and it was incorporated into all subsequent databases.

4. For the uranium oxides, known errors are the following:

$\mathrm{UO}_{2}(\mathrm{G})$ (G representing gummite) is really $\mathrm{UO}_{3}(\mathrm{G})$. HSC references Phillips 88 for the $\mathrm{UO}_{2}(\mathrm{G})$ data. But Phillips 88 lists data for $\mathrm{UO}_{3}(\mathrm{G})$ that are identical to those given by $\mathrm{HSC}$ for $\mathrm{UO}_{2}(\mathrm{G})$ and does not list $\mathrm{UO}_{2}(\mathrm{G})$. If you are interested in using this data, enter it into Own Database as $\mathrm{UO}_{3}(\mathrm{G})$. Each time that you do calculations, delete $\mathrm{UO}_{2}(\mathrm{G})$ from the list of compounds.

$\mathrm{U}_{3} \mathrm{O}_{5}$ listed is actually $\mathrm{U}_{3} \mathrm{O}_{8}$, better data for which are in the database. The data attributed to Samsonov 78 for $\mathrm{U}_{3} \mathrm{O}_{5}$ is very close to the values for $\mathrm{U}_{3} \mathrm{O}_{8}$ attributed to Barin 89. Therefore, when doing calculations each time, delete $\mathrm{U}_{3} \mathrm{O}_{5}$ from the list of compounds.

Also, duplicate data are tabulated for many compounds by normalizing the stoichiometry to 1 atom of the metal. Thus, for uranium oxides there are listings for equivalents as follows:

$\begin{array}{lc}\text { Primary } & \text { Equivalent } \\ \mathrm{U}_{4} \mathrm{O}_{9} & \mathrm{UO}_{2.25} \\ \mathrm{U}_{3} \mathrm{O} 7 & \mathrm{UO}_{2.33} \\ \mathrm{U}_{3} \mathrm{O}_{8} & \mathrm{UO}_{2.67} \\ \mathrm{UO}_{3} & \mathrm{UO}_{3}(\mathrm{~A}) ; \mathrm{UO}_{3}(\mathrm{~B})\end{array}$

The calculated results will split, for example, $\mathrm{U}_{3} \mathrm{O}_{8}$ half to each $\mathrm{U}_{3} \mathrm{O}_{8}$ and $\mathrm{UO}_{2.67}$. Therefore, to avoid this confusion, delete the repetitive species. Also, as discussed earlier, delete the bogus $\mathrm{UO}_{2}(\mathrm{G})$ and $\mathrm{U}_{3} \mathrm{O}_{5}$ species. In addition to the primary species listed above, include $\mathrm{UO}_{2}$.

Furthermore, $\mathrm{SrUO}_{4}$ is absent from the standard HSC database, and it is a significant compound, so HSC users should add data on $\mathrm{SrUO}_{4}$ to $\mathrm{HSC}$ when doing fission product calculations. 
Table B-1. Fission product groups used for code comparisons and fractional yields for case with $\mathrm{b}=66 \mathrm{MWd} / \mathrm{kg}, \mathrm{e}=10 \%$.

\begin{tabular}{|c|c|c|}
\hline $\begin{array}{c}\text { Group } \\
\text { Name }\end{array}$ & Elements & \\
& Main 6 groups (94.5\% of FP) & Fraction \\
\hline $\mathrm{Zr}$ & $\mathrm{Zr}$ & $1.386 \mathrm{E}-01$ \\
\hline $\mathrm{Xe}$ & $(\mathrm{Xe}+\mathrm{Kr})$ & $1.497 \mathrm{E}-01$ \\
\hline $\mathrm{Mo}$ & $(\mathrm{Mo}+\mathrm{Tc}+\mathrm{Ru})$ & $2.175 \mathrm{E}-01$ \\
\hline $\mathrm{La}$ & $(\mathrm{Y}+\mathrm{La}+\mathrm{Ce}+\mathrm{Pr}+\mathrm{Nd}+\mathrm{Pm}+\mathrm{Sm}+\mathrm{Eu}+\mathrm{Gd}+\mathrm{Nb})$ & $2.609 \mathrm{E}-01$ \\
\hline $\mathrm{Cs}$ & $(\mathrm{Cs}+\mathrm{Rb}+\mathrm{Rh})$ & $1.039 \mathrm{E}-01$ \\
\hline $\mathrm{Sr}$ & $(\mathrm{Sr}+\mathrm{Ba})$ & $7.433 \mathrm{E}-02$ \\
\hline & $(\mathrm{Pd}+\mathrm{Ag})$ & $3.024 \mathrm{E}-02$ \\
\hline $\mathrm{Pd}$ & $(\mathrm{Te}+\mathrm{Se})$ & $1.407 \mathrm{E}-02$ \\
\hline $\mathrm{Te}$ & $(\mathrm{I}+\mathrm{Br})$ & $6.879 \mathrm{E}-03$ \\
\hline $\mathrm{I}$ & $(\mathrm{Cd}+\mathrm{Sn}+\mathrm{Sb})$ & $3.563 \mathrm{E}-03$ \\
\hline $\mathrm{Cd}$ & & $9.998 \mathrm{E}-01$ \\
\hline & & \\
\hline & & \\
\hline
\end{tabular}


Table B-2. Input data for equilibrium codes. Quantities (mol/fuel pebble) of fission products generated, fuels remaining, and $\mathrm{O}_{2}$ and $\mathrm{C}$ released vs. burnup for a case with $\mathrm{c}=30 \%$ and $\mathrm{e}=10 \%$.

\begin{tabular}{|c|c|c|c|c|c|c|c|}
\hline $\mathrm{MWd} / \mathrm{kg}$ & 18.6 & 34.2 & 49.9 & 65.6 & 81.3 & 96.9 & 112.6 \\
\hline U atomic burnup & $1.992 \mathrm{E}-02$ & $3.638 \mathrm{E}-02$ & $\overline{5.266 \mathrm{E}-02}$ & $6.881 \mathrm{E}-02$ & $8.483 \mathrm{E}-02$ & $1.008 \mathrm{E}-01$ & $1.167 \mathrm{E}-01$ \\
\hline \multirow[t]{2}{*}{ Days } & 213 & 393 & 573 & 753 & 933 & 1113 & 1293 \\
\hline & $\mathrm{mol} / \mathrm{pebble}$ & & & & & & \\
\hline $\mathrm{Zr}$ & $2.265 \mathrm{E}-04$ & $4.011 \mathrm{E}-04$ & $5.659 \mathrm{E}-04$ & $7.223 \mathrm{E}-04$ & $8.712 \mathrm{E}-04$ & $1.014 \mathrm{E}-03$ & $1.150 \mathrm{E}-03$ \\
\hline $\mathrm{Xe}+\mathrm{Kr}$ & $2.247 \mathrm{E}-04$ & $4.107 \mathrm{E}-04$ & $5.956 \mathrm{E}-04$ & $7.798 \mathrm{E}-04$ & $9.636 \mathrm{E}-04$ & $1.149 \mathrm{E}-03$ & $1.332 \mathrm{E}-03$ \\
\hline $\mathrm{Mo}+\mathrm{Tc}+\mathrm{Ru}$ & $3.058 \mathrm{E}-04$ & $5.792 \mathrm{E}-04$ & $8.560 \mathrm{E}-04$ & $1.133 \mathrm{E}-03$ & $1.411 \mathrm{E}-03$ & $1.690 \mathrm{E}-03$ & $1.969 \mathrm{E}-03$ \\
\hline $\begin{array}{l}\mathrm{La}+\mathrm{Y}+\mathrm{Ce}+\mathrm{Pr}+\mathrm{Nd}+\mathrm{Pm}+\mathrm{Sm} \\
+\mathrm{Eu}+\mathrm{Gd}+\mathrm{Nb}\end{array}$ & 4.104E-04 & $7.359 \mathrm{E}-04$ & $1.051 \mathrm{E}-03$ & $1.360 \mathrm{E}-03$ & $1.662 \mathrm{E}-03$ & $1.960 \mathrm{E}-03$ & $2.253 \mathrm{E}-03$ \\
\hline $\mathrm{Cs}+\mathrm{Rb}+\mathrm{Rh}$ & $1.534 \mathrm{E}-04$ & $2.871 \mathrm{E}-04$ & $4.167 \mathrm{E}-04$ & $5.415 \mathrm{E}-04$ & $6.612 \mathrm{E}-04$ & $7.757 \mathrm{E}-04$ & $8.840 \mathrm{E}-04$ \\
\hline $\mathrm{Sr}+\mathrm{Ba}$ & $1.312 \mathrm{E}-04$ & $2.208 \mathrm{E}-04$ & $3.059 \mathrm{E}-04$ & $3.873 \mathrm{E}-04$ & $4.659 \mathrm{E}-04$ & $5.424 \mathrm{E}-04$ & $6.165 \mathrm{E}-04$ \\
\hline $\mathrm{UO}_{2}$ left & $2.598 \mathrm{E}-02$ & $2.554 \mathrm{E}-02$ & $2.511 \mathrm{E}-02$ & $2.468 \mathrm{E}-02$ & $2.426 \mathrm{E}-02$ & $2.383 \mathrm{E}-02$ & $2.341 \mathrm{E}-02$ \\
\hline $\mathrm{UC}_{2}$ left & $1.113 \mathrm{E}-02$ & $1.095 \mathrm{E}-02$ & $1.076 \mathrm{E}-02$ & $1.058 \mathrm{E}-02$ & $1.040 \mathrm{E}-02$ & $1.021 \mathrm{E}-02$ & $1.003 \mathrm{E}-02$ \\
\hline $\mathrm{C}$ & $1.353 \mathrm{E}-01$ & $1.349 \mathrm{E}-01$ & $1.345 \mathrm{E}-01$ & $1.342 \mathrm{E}-01$ & $1.338 \mathrm{E}-01$ & $1.334 \mathrm{E}-01$ & $1.331 \mathrm{E}-01$ \\
\hline $\mathrm{O}_{2}$ & $5.281 \mathrm{E}-04$ & $9.641 \mathrm{E}-04$ & $1.396 \mathrm{E}-03$ & $1.824 \mathrm{E}-03$ & $2.248 \mathrm{E}-03$ & $2.673 \mathrm{E}-03$ & $3.093 \mathrm{E}-03$ \\
\hline $\mathrm{Pu}$ & $2.731 \mathrm{E}-04$ & $4.343 \mathrm{E}-04$ & $5.627 \mathrm{E}-04$ & $6.636 \mathrm{E}-04$ & $7.403 \mathrm{E}-04$ & 7.992E-04 & $8.065 \mathrm{E}-04$ \\
\hline
\end{tabular}


Table B3. Possible substances resulting from 11 input materials $\left(\mathrm{UO}_{2}, \mathrm{UC}_{2}, \mathrm{Pu}, \mathrm{O}_{2}, \mathrm{C}, \mathrm{Zr}, \mathrm{Xe}, \mathrm{Mo}, \mathrm{La}\right.$, $\mathrm{Cs}, \mathrm{Sr}$ ). (Shaded boxes were not used in computations.)

\begin{tabular}{|c|c|}
\hline HSC & FACTSAGE \\
\hline C & $\mathrm{C}$ \\
\hline C(A) & C(s) \\
\hline C(D) & C(s2) \\
\hline $\mathrm{C}(\mathrm{g})$ & $\mathrm{C}(\mathrm{g})$ \\
\hline $\mathrm{C}_{2}(\mathrm{~g})$ & $\mathrm{C}_{2}(\mathrm{~g})$ \\
\hline $\mathrm{C}_{2} \mathrm{O}(\mathrm{g})$ & $\mathrm{C}_{2} \mathrm{O}(\mathrm{g})$ \\
\hline $\mathrm{C}_{3}(\mathrm{~g})$ & $\mathrm{C}_{3}(\mathrm{~g})$ \\
\hline $\mathrm{C}_{3} \mathrm{O}_{2}(\mathrm{~g})$ & $\mathrm{C}_{3} \mathrm{O}_{2}(\mathrm{~g})$ \\
\hline $\mathrm{C}_{4}(\mathrm{~g})$ & $\mathrm{C}_{4}(\mathrm{~g})$ \\
\hline $\mathrm{C}_{5}(\mathrm{~g})$ & $\mathrm{C}_{5}(\mathrm{~g})$ \\
\hline $\mathrm{CO}(\mathrm{g})$ & $\mathrm{CO}(\mathrm{g})$ \\
\hline $\mathrm{CO}_{2}(\mathrm{~g})$ & $\mathrm{CO}_{2}(\mathrm{~g})$ \\
\hline \multirow[t]{2}{*}{ Cs } & $\operatorname{Cs}(\mathrm{s})$ \\
\hline & $\mathrm{Cs}(\mathrm{liq})$ \\
\hline $\mathrm{Cs}(\mathrm{g})$ & $\mathrm{Cs}(\mathrm{g})$ \\
\hline $\mathrm{Cs}_{2}(\mathrm{~g})$ & $\mathrm{Cs}_{2}(\mathrm{~g})$ \\
\hline $\mathrm{Cs}_{2} \mathrm{CO}_{3}$ & $\mathrm{Cs}_{2} \mathrm{CO}_{3}(\mathrm{~s})$ \\
\hline $\mathrm{Cs}_{2} \mathrm{CO}_{3}(\mathrm{~g})$ & \\
\hline $\mathrm{Cs}_{2} \mathrm{MO}_{2} \mathrm{O}_{7}$ & $\mathrm{Cs}_{2} \mathrm{MO}_{2} \mathrm{O}_{7}(\mathrm{~s})$ \\
\hline \multirow[t]{8}{*}{$\mathrm{Cs}_{2} \mathrm{O} * \mathrm{MoO}_{3}$} & \\
\hline & $\mathrm{Cs}_{2} \mathrm{Mo}_{3} \mathrm{O}_{10}(\mathrm{~s})$ \\
\hline & $\mathrm{Cs}_{2} \mathrm{Mo}_{4} \mathrm{O}_{13}(\mathrm{~s})$ \\
\hline & $\mathrm{Cs}_{2} \mathrm{Mo}_{5} \mathrm{O}_{16}(\mathrm{~s})$ \\
\hline & $\mathrm{Cs}_{2} \mathrm{Mo}_{7} \mathrm{O}_{22}(\mathrm{~s})$ \\
\hline & $\mathrm{Cs}_{2} \mathrm{MoO}_{4}(\mathrm{~g})$ \\
\hline & $\mathrm{Cs}_{2} \mathrm{MoO}_{4}$ (liq) \\
\hline & $\mathrm{Cs}_{2} \mathrm{MoO}_{4}(\mathrm{~s})$ \\
\hline $\mathrm{Cs}_{2} \mathrm{O}$ & $\mathrm{Cs}_{2} \mathrm{MoO}_{4}(\mathrm{~s} 2)$ \\
\hline $\mathrm{Cs}_{2} \mathrm{O}(\mathrm{g})$ & $\mathrm{Cs}_{2} \mathrm{O}(\mathrm{s})$ \\
\hline
\end{tabular}

\begin{tabular}{|c|c|}
\hline HSC & FACTSAGE \\
\hline $\mathrm{Cs}_{2} \mathrm{O}_{2}$ & $\mathrm{Cs}_{2} \mathrm{O}(\mathrm{g})$ \\
\hline $\mathrm{Cs}_{2} \mathrm{O}_{2}(\mathrm{~g})$ & $\mathrm{Cs}_{2} \mathrm{O}_{2}(\mathrm{~s})$ \\
\hline \multicolumn{2}{|l|}{$\mathrm{Cs}_{2} \mathrm{O}_{3}$} \\
\hline & $\mathrm{Cs}_{2} \mathrm{O}_{3}(\mathrm{~g})$ \\
\hline & $\mathrm{Cs}_{2} \mathrm{U}_{15} \mathrm{O}_{46}(\mathrm{~s})$ \\
\hline $\mathrm{Cs}_{2} \mathrm{U}_{2} \mathrm{O} 7$ & $\mathrm{Cs}_{2} \mathrm{U}_{2} \mathrm{O}_{7}(\mathrm{~s})$ \\
\hline \multirow[t]{7}{*}{$\mathrm{Cs}_{2} \mathrm{U}_{4} \mathrm{Ol}_{2}$} & $\mathrm{Cs}_{2} \mathrm{U}_{4} \mathrm{O}_{12}(\mathrm{~s})$ \\
\hline & $\mathrm{Cs}_{2} \mathrm{U}_{4} \mathrm{O}_{12}(\mathrm{~s} 2)$ \\
\hline & $\mathrm{Cs}_{2} \mathrm{U}_{4} \mathrm{O}_{13}(\mathrm{~s})$ \\
\hline & $\mathrm{Cs}_{2} \mathrm{U}_{5} \mathrm{O}_{16}(\mathrm{~s})$ \\
\hline & $\mathrm{Cs}_{2} \mathrm{U}_{6} \mathrm{O}_{18}(\mathrm{~s})$ \\
\hline & $\mathrm{Cs}_{2} \mathrm{U}_{7} \mathrm{O}_{22}(\mathrm{~s})$ \\
\hline & $\mathrm{Cs}_{2} \mathrm{U}_{9} \mathrm{O}_{27}(\mathrm{~s})$ \\
\hline \multirow[t]{6}{*}{$\mathrm{Cs}_{2} \mathrm{UO}_{4}$} & $\mathrm{Cs}_{2} \mathrm{UO}_{4}(\mathrm{~s})$ \\
\hline & $\mathrm{Cs}_{2} \mathrm{Zr}_{2} \mathrm{O}_{5}(\mathrm{~s})$ \\
\hline & $\mathrm{Cs}_{2} \mathrm{Zr}_{3} \mathrm{O}_{7}(\mathrm{~s})$ \\
\hline & $\mathrm{Cs}_{2} \mathrm{ZrO}_{3}(\mathrm{~s})$ \\
\hline & $\mathrm{Cs}_{4} \mathrm{U}_{2} \mathrm{O}_{7}(\mathrm{~s})$ \\
\hline & $\mathrm{Cs}_{4} \mathrm{U}_{5} \mathrm{O}_{17}(\mathrm{~s})$ \\
\hline $\mathrm{CsO}(\mathrm{g})$ & $\mathrm{CsO}(\mathrm{g})$ \\
\hline $\mathrm{CsO}_{2}$ & $\mathrm{CsO}_{2}(\mathrm{~s})$ \\
\hline \multirow[t]{2}{*}{$\mathrm{La}$} & $\mathrm{La}(\mathrm{s})$ \\
\hline & La(liq) \\
\hline \multirow[t]{4}{*}{$\mathrm{La}(\mathrm{g})$} & $\mathrm{La}(\mathrm{g})$ \\
\hline & $\mathrm{La}(\mathrm{s} 2)$ \\
\hline & $\mathrm{La}(\mathrm{s} 3)$ \\
\hline & $\mathrm{La}_{2}\left(\mathrm{CO}_{3}\right)_{3}(\mathrm{~s})$ \\
\hline $\mathrm{La}_{2}(\mathrm{~g})$ & $\mathrm{La}_{2}(\mathrm{~g})$ \\
\hline $\mathrm{La}_{2} \mathrm{O}(\mathrm{g})$ & $\mathrm{La}_{2} \mathrm{O}(\mathrm{g})$ \\
\hline
\end{tabular}

\begin{tabular}{|c|c|}
\hline HSC & FACTSAGE \\
\hline \multirow[t]{2}{*}{$\mathrm{La}_{2} \mathrm{O}_{2}(\mathrm{~g})$} & $\mathrm{La}_{2} \mathrm{O}_{2}(\mathrm{~g})$ \\
\hline & $\mathrm{La}_{2} \mathrm{O}_{3}$ (liq) \\
\hline $\mathrm{La}_{2} \mathrm{O}_{3}$ & $\mathrm{La}_{2} \mathrm{O}_{3}(\mathrm{~s})$ \\
\hline $\mathrm{La}_{2} \mathrm{O}_{3} * 3 \mathrm{MoO}_{3}$ & \\
\hline \multicolumn{2}{|l|}{$\mathrm{La}_{3}\left(\mathrm{MoO}_{4}\right)_{3}$} \\
\hline $\mathrm{LaC}_{2}$ & $\mathrm{LaC}_{2}(\mathrm{~s})$ \\
\hline $\mathrm{LaC}_{2}(\mathrm{~g})$ & $\mathrm{LaC}_{2}(\mathrm{~g})$ \\
\hline $\mathrm{LaO}(\mathrm{g})$ & $\mathrm{LaO}(\mathrm{g})$ \\
\hline \multicolumn{2}{|l|}{$\mathrm{LaO}_{2}(\mathrm{~g})$} \\
\hline \multirow[t]{2}{*}{ Mo } & $\mathrm{Mo}(\mathrm{s})$ \\
\hline & Mo(liq) \\
\hline $\operatorname{Mo}(\mathrm{g})$ & $\operatorname{Mo}(\mathrm{g})$ \\
\hline $\mathrm{MoO}_{2}$ & $\mathrm{MoO}_{2}(\mathrm{~g})$ \\
\hline $\mathrm{Mo}(\mathrm{CO})_{6}$ & $\mathrm{Mo}(\mathrm{CO})_{6}(\mathrm{~s})$ \\
\hline $\mathrm{Mo}(\mathrm{CO})_{6}(\mathrm{~g})$ & $\mathrm{Mo}(\mathrm{CO})_{6}(\mathrm{~g})$ \\
\hline $\mathrm{MoC}$ & $\mathrm{MoC}(\mathrm{s})$ \\
\hline $\mathrm{MO}_{2} \mathrm{C}$ & $\mathrm{MO}_{2} \mathrm{C}(\mathrm{s})$ \\
\hline $\mathrm{Mo}_{3} \mathrm{C}_{2}$ & NEEDED? \\
\hline \multicolumn{2}{|l|}{$\mathrm{MoC}_{0.47}$} \\
\hline \multicolumn{2}{|l|}{$\mathrm{MoC}_{0.4815}$} \\
\hline \multicolumn{2}{|l|}{$\mathrm{MoC}_{0.487}$} \\
\hline \multicolumn{2}{|l|}{$\mathrm{MoC}_{0.5}$} \\
\hline \multicolumn{2}{|l|}{$\mathrm{MoC}_{0.64}$} \\
\hline \multicolumn{2}{|l|}{$\mathrm{MoC}_{0.68}$} \\
\hline $\mathrm{MoO}(\mathrm{g})$ & $\mathrm{MoO}(\mathrm{g})$ \\
\hline $\mathrm{MoO}_{2}$ & $\mathrm{MoO}_{2}(\mathrm{~s})$ \\
\hline $\mathrm{MoO}_{2}(\mathrm{~g})$ & $\mathrm{MoO}_{2}(\mathrm{~g})$ \\
\hline \multirow[t]{2}{*}{$\mathrm{MoO}_{3}$} & $\mathrm{MoO}_{3}(\mathrm{~s})$ \\
\hline & $\mathrm{MoO}_{3}$ (liq) \\
\hline
\end{tabular}

\begin{tabular}{|c|c|}
\hline HSC & FACTSAGE \\
\hline $\mathrm{MoO}_{3}(\mathrm{~g})$ & $\mathrm{MoO}_{3}(\mathrm{~g})$ \\
\hline $\mathrm{MO}_{2} \mathrm{O}_{6}(\mathrm{~g})$ & $\mathrm{MO}_{2} \mathrm{O}_{6}(\mathrm{~g})$ \\
\hline $\mathrm{Mo}_{3} \mathrm{O}_{9}(\mathrm{~g})$ & $\mathrm{Mo}_{3} \mathrm{O}_{9}(\mathrm{~g})$ \\
\hline \multicolumn{2}{|l|}{$\mathrm{Mo}_{4} \mathrm{O}_{11}$} \\
\hline $\mathrm{Mo}_{4} \mathrm{O}_{12}(\mathrm{~g})$ & $\mathrm{Mo}_{4} \mathrm{O}_{12}(\mathrm{~g})$ \\
\hline $\mathrm{Mo5O}_{15}(\mathrm{~g})$ & $\mathrm{Mo}_{5} \mathrm{O}_{15}(\mathrm{~g})$ \\
\hline $\mathrm{MoO}_{2.75}$ & \\
\hline $\mathrm{MoO}_{2.875}$ & \\
\hline \multicolumn{2}{|l|}{$\mathrm{MoO}_{2.889}$} \\
\hline $\mathrm{O}(\mathrm{g})$ & $\mathrm{O}(\mathrm{g})$ \\
\hline $\mathrm{CsO}_{2}$ & $\mathrm{CsO}_{2}(\mathrm{~s})$ \\
\hline \multirow[t]{2}{*}{$\mathrm{La}$} & $\mathrm{La}(\mathrm{s})$ \\
\hline & $\mathrm{La}(\mathrm{liq})$ \\
\hline \multirow[t]{4}{*}{$\mathrm{La}(\mathrm{g})$} & $\mathrm{La}(\mathrm{g})$ \\
\hline & $\mathrm{La}(\mathrm{s} 2)$ \\
\hline & $\mathrm{La}(\mathrm{s} 3)$ \\
\hline & $\mathrm{La}_{2}\left(\mathrm{CO}_{3}\right)_{3}(\mathrm{~s})$ \\
\hline $\mathrm{La}_{2}(\mathrm{~g})$ & $\mathrm{La}_{2}(\mathrm{~g})$ \\
\hline $\mathrm{La}_{2} \mathrm{O}(\mathrm{g})$ & $\mathrm{La}_{2} \mathrm{O}(\mathrm{g})$ \\
\hline \multirow[t]{2}{*}{$\mathrm{La}_{2} \mathrm{O}_{2}(\mathrm{~g})$} & $\mathrm{La}_{2} \mathrm{O}_{2}(\mathrm{~g})$ \\
\hline & $\mathrm{La}_{2} \mathrm{O}_{3}(\mathrm{liq})$ \\
\hline $\mathrm{La}_{2} \mathrm{O}_{3}$ & $\mathrm{La}_{2} \mathrm{O}_{3}(\mathrm{~s})$ \\
\hline $\mathrm{La}_{2} \mathrm{O}_{3} * 3 \mathrm{MoO}_{3}$ & \\
\hline \multicolumn{2}{|l|}{$\mathrm{La}_{3}\left(\mathrm{MoO}_{4}\right)_{3}$} \\
\hline $\mathrm{LaC}_{2}$ & $\mathrm{LaC}_{2}(\mathrm{~s})$ \\
\hline $\mathrm{LaC}_{2}(\mathrm{~g})$ & $\mathrm{LaC}_{2}(\mathrm{~g})$ \\
\hline $\mathrm{LaO}(\mathrm{g})$ & $\mathrm{LaO}(\mathrm{g})$ \\
\hline $\mathrm{LaO}_{2}(\mathrm{~g})$ & \\
\hline
\end{tabular}




\begin{tabular}{|c|c|c|c|}
\hline $\mathrm{HSC}$ & FACTSAGE & $\mathrm{HSC}$ & FACTSAGE \\
\hline \multirow[t]{2}{*}{ Mo } & $\mathrm{Mo}(\mathrm{s})$ & $\mathrm{CsO}_{2}$ & $\mathrm{CsO}_{2}(\mathrm{~s})$ \\
\hline & Mo(liq) & \multirow[t]{2}{*}{$\mathrm{La}$} & $\mathrm{La}(\mathrm{s})$ \\
\hline $\operatorname{Mo}(\mathrm{g})$ & $\operatorname{Mo}(g)$ & & $\mathrm{La}(\mathrm{liq})$ \\
\hline $\mathrm{MoO}_{2}$ & $\mathrm{MoO}_{2}(\mathrm{~g})$ & \multirow[t]{4}{*}{$\mathrm{La}(\mathrm{g})$} & $\mathrm{La}(\mathrm{g})$ \\
\hline $\mathrm{Mo}(\mathrm{CO})_{6}$ & $\mathrm{Mo}(\mathrm{CO})_{6}(\mathrm{~s})$ & & $\mathrm{La}(\mathrm{s} 2)$ \\
\hline $\mathrm{Mo}(\mathrm{CO})_{6}(\mathrm{~g})$ & $\mathrm{Mo}(\mathrm{CO})_{6}(\mathrm{~g})$ & & $\mathrm{La}(\mathrm{s} 3)$ \\
\hline $\mathrm{MoC}$ & $\mathrm{MoC}(\mathrm{s})$ & & $\mathrm{La}_{2}\left(\mathrm{CO}_{3}\right)_{3}(\mathrm{~s})$ \\
\hline $\mathrm{MO}_{2} \mathrm{C}$ & $\mathrm{MO}_{2} \mathrm{C}(\mathrm{s})$ & $\mathrm{La}_{2}(\mathrm{~g})$ & $\mathrm{La}_{2}(\mathrm{~g})$ \\
\hline $\mathrm{Mo}_{3} \mathrm{C}_{2}$ & NEEDED? & $\mathrm{La}_{2} \mathrm{O}(\mathrm{g})$ & $\mathrm{La}_{2} \mathrm{O}(\mathrm{g})$ \\
\hline $\mathrm{MoC}_{0.47}$ & & $\mathrm{La}_{2} \mathrm{O}_{2}(\mathrm{~g})$ & $\mathrm{La}_{2} \mathrm{O}_{2}(\mathrm{~g})$ \\
\hline $\mathrm{MoC}_{0.4815}$ & & & $\mathrm{La}_{2} \mathrm{O}_{3}(\mathrm{liq})$ \\
\hline $\mathrm{MoC}_{0.487}$ & & $\mathrm{La}_{2} \mathrm{O}_{3}$ & $\mathrm{La}_{2} \mathrm{O}_{3}(\mathrm{~s})$ \\
\hline $\mathrm{MoC}_{0.5}$ & & $\mathrm{La}_{2} \mathrm{O}_{3} * 3 \mathrm{MoO}_{3}$ & \\
\hline $\mathrm{MoC}_{0.64}$ & & $\mathrm{La}_{3}\left(\mathrm{MoO}_{4}\right)_{3}$ & \\
\hline $\mathrm{MoC}_{0.68}$ & & $\mathrm{LaC}_{2}$ & $\mathrm{LaC}_{2}(\mathrm{~s})$ \\
\hline $\mathrm{MoO}(\mathrm{g})$ & $\mathrm{MoO}(\mathrm{g})$ & $\mathrm{LaC}_{2}(\mathrm{~g})$ & $\mathrm{LaC}_{2}(\mathrm{~g})$ \\
\hline $\mathrm{MoO}_{2}$ & $\mathrm{MoO}_{2}(\mathrm{~s})$ & $\mathrm{LaO}(\mathrm{g})$ & $\mathrm{LaO}(\mathrm{g})$ \\
\hline $\mathrm{MoO}_{2}(\mathrm{~g})$ & $\mathrm{MoO}_{2}(\mathrm{~g})$ & $\mathrm{LaO}_{2}(\mathrm{~g})$ & \\
\hline \multirow[t]{2}{*}{$\mathrm{MoO}_{3}$} & $\mathrm{MoO}_{3}(\mathrm{~s})$ & \multirow[t]{2}{*}{ Mo } & $\operatorname{Mo}(\mathrm{s})$ \\
\hline & $\mathrm{MoO}_{3}$ (liq) & & Mo(liq) \\
\hline $\mathrm{MoO}_{3}(\mathrm{~g})$ & $\mathrm{MoO}_{3}(\mathrm{~g})$ & $\operatorname{Mo}(g)$ & $\operatorname{Mo}(\mathrm{g})$ \\
\hline $\mathrm{MO}_{2} \mathrm{O}_{6}(\mathrm{~g})$ & $\mathrm{MO}_{2} \mathrm{O}_{6}(\mathrm{~g})$ & $\mathrm{MoO}_{2}$ & $\mathrm{MoO}_{2}(\mathrm{~g})$ \\
\hline $\mathrm{Mo}_{3} \mathrm{O}_{9}(\mathrm{~g})$ & $\mathrm{Mo}_{3} \mathrm{O}_{9}(\mathrm{~g})$ & $\mathrm{Mo}(\mathrm{CO})_{6}$ & $\mathrm{Mo}(\mathrm{CO})_{6}(\mathrm{~s})$ \\
\hline $\mathrm{Mo}_{4} \mathrm{O}_{11}$ & & $\mathrm{Mo}(\mathrm{CO})_{6}(\mathrm{~g})$ & $\mathrm{Mo}(\mathrm{CO})_{6}(\mathrm{~g})$ \\
\hline $\mathrm{Mo}_{4} \mathrm{O}_{12}(\mathrm{~g})$ & $\mathrm{Mo}_{4} \mathrm{O}_{12}(\mathrm{~g})$ & $\mathrm{MoC}$ & $\mathrm{MoC}(\mathrm{s})$ \\
\hline $\mathrm{Mo5O}_{15}(\mathrm{~g})$ & $\mathrm{Mo}_{5} \mathrm{O}_{15}(\mathrm{~g})$ & $\mathrm{MO}_{2} \mathrm{C}$ & $\mathrm{MO}_{2} \mathrm{C}(\mathrm{s})$ \\
\hline $\mathrm{MoO}_{2.75}$ & & $\mathrm{Mo}_{3} \mathrm{C}_{2}$ & NEEDED? \\
\hline $\mathrm{MoO}_{2.875}$ & & $\mathrm{MoC}_{0.47}$ & \\
\hline $\mathrm{MoO}_{2.889}$ & & $\mathrm{MoC}_{0.4815}$ & \\
\hline $\mathrm{O}(\mathrm{g})$ & $\mathrm{O}(\mathrm{g})$ & $\mathrm{MoC}_{0.487}$ & \\
\hline & & $\mathrm{MoC}_{0.5}$ & \\
\hline
\end{tabular}

\begin{tabular}{|l|l|}
\hline \multicolumn{1}{|c|}{$\mathrm{HSC}$} & $\mathrm{FACTSAGE}$ \\
\hline $\mathrm{MoC}_{0.64}$ & \\
\hline $\mathrm{MoC}_{0.68}$ & \\
\hline $\mathrm{MoO}(\mathrm{g})$ & $\mathrm{MoO}(\mathrm{g})$ \\
\hline $\mathrm{MoO}_{2}$ & $\mathrm{MoO}_{2}(\mathrm{~s})$ \\
\hline $\mathrm{MoO}_{2}(\mathrm{~g})$ & $\mathrm{MoO}_{2}(\mathrm{~g})$ \\
\hline $\mathrm{MoO}_{3}$ & $\mathrm{MoO}_{3}(\mathrm{~s})$ \\
\hline & $\mathrm{MoO}_{3}(\mathrm{liq})$ \\
\hline $\mathrm{MoO}_{3}(\mathrm{~g})$ & $\mathrm{MoO}_{3}(\mathrm{~g})$ \\
\hline $\mathrm{MO}_{2} \mathrm{O}_{6}(\mathrm{~g})$ & $\mathrm{MO}_{2} \mathrm{O}_{6}(\mathrm{~g})$ \\
\hline $\mathrm{Mo}_{3} \mathrm{O}_{9}(\mathrm{~g})$ & $\mathrm{Mo}_{3} \mathrm{O}_{9}(\mathrm{~g})$ \\
\hline $\mathrm{Mo}_{4} \mathrm{O}_{11}$ & \\
\hline $\mathrm{Mo}_{4} \mathrm{O}_{12}(\mathrm{~g})$ & $\mathrm{Mo}_{4} \mathrm{O}_{12}(\mathrm{~g})$ \\
\hline $\mathrm{Mo5O}_{15}(\mathrm{~g})$ & $\mathrm{Mo}_{5} \mathrm{O}_{15}(\mathrm{~g})$ \\
\hline $\mathrm{MoO}_{2.75}$ & \\
\hline $\mathrm{MoO}_{2.875}$ & \\
\hline $\mathrm{MoO}_{2.889}$ & \\
\hline $\mathrm{O}_{(\mathrm{g})}$ & $\left.\mathrm{O}_{\mathrm{g}}\right)$ \\
\hline & \\
\hline
\end{tabular}


Table B4. Some inconsistencies between internal databases of HSC and FACTSAGE. Gibbs energies of compounds $\mathrm{G}(\mathrm{kJ} / \mathrm{mol})$ (not $\Delta \mathrm{G}_{\mathrm{f}}{ }^{\text {ofor }}$ formation of the compounds) at $1300 \mathrm{~K}$.

\begin{tabular}{|c|c|c|c|c|c|c|}
\hline Substance & $\mathrm{HSC}$ & Reference & FACTSAGE & Reference & Variation & Resolution \\
\hline $\mathrm{LaC}_{2}$ & -257.98 & $\begin{array}{c}\text { Kosolapovoi } \\
86\end{array}$ & -218.19 & Wagman 68-71 & $15 \%$ & Use HSC data \\
\hline $\mathrm{Mo}_{2} \mathrm{C}$ & -203.56 & Barin 89 & -194.26 & Barin 77 & $5 \%$ & Use HSC data \\
\hline $\mathrm{MoC}$ & -111.25 & Knacke 91 & -97.974 & Barin 77 & $12 \%$ & Use HSC data \\
\hline $\mathrm{Pu}_{2} \mathrm{O}_{3}$ & $-2,141.1$ & Barin 93 & $-1,988.3$ & Cordfunke 90 & $7 \%$ & Use HSC data \\
\hline $\mathrm{SrC}_{2}$ & -232.29 & Barin 89 & -241.76 & Barin 77 & $4 \%$ & Use HSC data \\
\hline $\mathrm{SrUO}_{4}$ & No data & None & -2562.9 & Heames 92 & infinite & Use FACTSAGE \\
\hline $\mathrm{UC}_{2}$ & -247.37 & Knacke 91 & No data & None & infinite & Use HSC data \\
\hline
\end{tabular}


Table B5. FACTSAGE and HSC comparison at $\mathrm{b}=113 \mathrm{MWd} / \mathrm{kg}, \mathrm{c}=30 \%$, e $=10 \%, \mathrm{~T}=1300 \mathrm{~K}$. Data are concentrations (mol per fuel pebble).

\begin{tabular}{|c|c|c|c|c|}
\hline $\mathrm{HSC}$ & & FACTSAGE & & REMARKS \\
\hline & 0.133 & $\mathrm{C}$ & 0.133 & Agree \\
\hline \multirow[t]{2}{*}{$\mathrm{CO}(\mathrm{g})$} & $2.00 \mathrm{E}-9$ & $\mathrm{CO}(\mathrm{g})$ & $1.97 \mathrm{E}-9$ & Agree \\
\hline & $8.02 \mathrm{E}-4$ & Cs & & FACTSAGE predicts no solid Cs. \\
\hline $\mathrm{Cs}(\mathrm{g})$ & $8.16 \mathrm{E}-5$ & $\mathrm{Cs}(\mathrm{g})$ & $8.72 \mathrm{E}-4$ & \\
\hline $\mathrm{Cs}_{2}(\mathrm{~g})$ & $8.72 \mathrm{E}-8$ & $\mathrm{Cs}_{2}(\mathrm{~g})$ & $5.85 \mathrm{E}-6$ & \\
\hline \multirow[t]{2}{*}{ Total Cs } & $8.84 E-4$ & Total Cs & $8.84 E-5$ & \\
\hline & $1.10 \mathrm{E}-3$ & $\mathrm{La}_{2} \mathrm{O}_{3}(\mathrm{~s})$ & $1.13 \mathrm{E}-3$ & $3 \%$ different \\
\hline \multirow[t]{2}{*}{$\mathrm{LaC}_{2}$} & $5.75 \mathrm{E}-5$ & & & FACTSAGE predicts no $\mathrm{LaC}_{2}$. \\
\hline & $8.07 \mathrm{E}-4$ & & & \\
\hline $\mathrm{Mo}_{2} \mathrm{C}$ & $1.02 \mathrm{E}-4$ & $\mathrm{Mo}_{2} \mathrm{C}$ & $9.85 \mathrm{E}-4$ & FACTSAGE predicts only one form of Mo. \\
\hline $\mathrm{Mo}_{3} \mathrm{C}_{2}$ & $3.02 \mathrm{E}-6$ & & & \\
\hline $\mathrm{MoC}$ & $9.49 \mathrm{E}-4$ & & & \\
\hline \multirow[t]{4}{*}{ Mo tot } & $1.97 E-3$ & Mo tot & $1.97 \mathrm{E}-3$ & \\
\hline & $4.03 \mathrm{E}-4$ & $\mathrm{Pu}_{2} \mathrm{O}_{3}(\mathrm{~s})$ & $4.03 \mathrm{E}-4$ & Agree \\
\hline & $6.16 \mathrm{E}-4$ & $\mathrm{SrUO}_{4}(\mathrm{~s})$ & $6.16 \mathrm{E}-4$ & Agree \\
\hline & $1.21 \mathrm{E}-3$ & $\mathrm{U}_{2} \mathrm{C}_{3}(\mathrm{~s})$ & $4.92 \mathrm{E}-3$ & FACTSAGE predicts only one carbide of $U$. \\
\hline $\mathrm{UC}$ & $3.86 \mathrm{E}-3$ & & & \\
\hline$\overline{\mathrm{UC}_{2}}$ & $3.49 \mathrm{E}-3$ & & & \\
\hline \multirow[t]{4}{*}{ carbide tot } & $9.77 \mathrm{E}-3$ & carbide tot & $9.84 \mathrm{E}-3$ & \\
\hline & $2.30 \mathrm{E}-2$ & $\mathrm{UO}_{2}(\mathrm{~s})$ & $2.30 \mathrm{E}-2$ & Agree \\
\hline & $1.33 \mathrm{E}-3$ & $\mathrm{Xe}(\mathrm{g})$ & $1.33 \mathrm{E}-3$ & Agree \\
\hline & $1.15 \mathrm{E}-3$ & $\mathrm{ZrC}_{4}$ & $1.15 \mathrm{E}-3$ & Agree \\
\hline
\end{tabular}




\section{APPENDIX C: PAPERS RELATED TO STRESS MODELLING}




\section{APPENDIX D: PAPER RELATED TO SECTION 2}

LDRD Appendix \PebbleBedPaper04.doc - Pebble Bed Paper 


\section{APPENDIX E: PAPERS RELATED TO SECTION 4}

LDRD Appendix \PEBBED_ANE_07_2002.pdf - Direct deterministic method

LDRD Appendix UHDGpaper.pdf - Matrix Formulation

LDRD Appendix

LDRD Appendix \CIM2002hdg.PDF - Modular Pebble Bed Reactor

LDRD AppendixlNov01 paper_2.pdf - Concept Design and Physics Analysis

$\underline{\text { LDRD Appendix } \backslash \text { PBRproliferation petten.pdf - PBR to Produce Plutonium }}$ 
